\title{
DIREITO FUNDAMENTAL À LIBERDADE DE REUNIÃo E CONTROLE DE CONSTITUCIONALIDADE DE LEIS PENAIS E DE SUA INTERPRETAÇÃO E APLICAÇÃO: CONTRIBUIÇÃO PARA O DIREITO DE REUNIÃO COMO SUB-RAMO AUTÔNOMO DO DIREITO ADMINISTRATIVO
}

\author{
THE FUNDAMENTAL RIGHT TO FREEDOM OF ASSEMBLY, CONSTITUTIONAL CONTROL OF CRIMINAL \\ LAWS AND ITS INTERPRETATION AND APPLICATION: A CONTRIBUTION TO THE UNDERSTANDING \\ OF THE RIGHT OF ASSEMBLY AS AN AUTONOMOUS SUB-BRANCH OF ADMINISTRATIVE LAW ${ }^{1}$
}

Leonardo Martins ${ }^{2}$

Resumo: Este é um estudo de caso antecedido por uma explanação sistemática de seus pressupostos teóricos. O caso é fictício, mas fortemente inspirado em uma decisão de Câmara do Tribunal Constitucional Federal alemão. Nela, tratava-se de avaliar a constitucionalidade de uma medida policial e sua confirmação judicial no contexto de uma contramanifestação a uma reunião que ocorria em local público. Para a sua solução, desenvolveu-se um parecer jurídico-constitucional cujo objeto é a situação jurídica presente no caso, com vistas a avaliar as chances de êxito de uma eventual ação judicial contra as medidas estatais (policiais e decisão judicial), considerando a hipótese da violação do direito fundamental à liberdade de reunião a ser testada. No que se refere aos pressupostos teóricos do caso e à conjuntura política e jurídica brasileira, tem-se o seguinte. Como ocorre em qualquer Estado democrático, também no Brasil sob a égide da Constituição Federal (CF) o entorno político-ideológico do direito fundamental à liberdade de reunião é tão notório quanto contraproducente, pelo menos quando se pensa na imprescindibilidade de uma abordagem especificamente técnico-jurídica constitucional. Há um déficit na discussão pátria que o presente ensaio visa a sanar à luz do direito comparado alemão. Conjugar, assistematicamente, o princípio democrático com a liberdade de reunião e seu suposto caráter instrumental em relação àquele não faz jus aos desafios hermenêuticos implícitos no complexo teor do art. $5^{\circ}$, XVI CF em que se positivou o direito fundamental à liberdade de reunião. Partindo de uma análise sistemática do texto constitucional, o presente ensaio apresenta definições jurídico-dogmáticas, metodologicamente disciplinadas, e analisa o teor do dispositivo, classificando suas locuções entre condições subjetivas para o exercício da liberdade de reunião e previsão implícita de seus limites constitucionais que, por sua vez, podem ser, atendido certo ônus argumentativo, concretamente traçados pelo legislador ordinário. Assim, uma legislação ordinária regulamentadora não poderia ser, de plano, descartada como inconstitucional. Também a interpretação e a aplicação dessa eventual lei regulamentadora, assim como no caso da interpretação de quaisquer outros dispositivos normativos pertinentes ao direito administrativo e penal em geral, devem ser interpretadas e aplicadas à luz do direito fundamental à liberdade de reunião, de tal sorte a serem observados os vínculos específicos de todos os órgãos estatais pertinentes às três funções estatais clássicas.

Palavras-chave: Autoaplicabilidade de direitos fundamentais. Regulamentação da liberdade de reunião. Limites constitucionais da liberdade de reunião. Interpretação judicial à luz da liberdade de reunião.

\footnotetext{
Pela inestimável colaboração na pesquisa de algumas das fontes bibliográficas brasileiras utilizadas no presente ensaio, agradeço aos membros do Grupo de Pesquisa "Constituição Federal e sua Concretização pela Justiça Constitucional - CFCJ" (PPGD-UFRN), mestres Fabrízia Serafim, LL.M. (London School of Economics and Political Sciences - LSE) e Jone Maciel (UFRN). Mais uma vez, pela tradução do resumo ao idioma inglês, agradeço à primeira. Ao também membro do CFCJ e mestre Guilherme Arruda (Humboldt-Universität zu Berlin - HUB) e ao meu colega Prof. Dr. Dimitri Dimoulis, agradeço pelas leituras críticas de versões prévias desse manuscrito. Deficiências do texto são de minha integral responsabilidade. Esta, que é uma primeira edição do ensaio (work in progress!), foi concluída durante as três primeiras semanas de minha sexta missão de pós-doutoramento realizada na Humboldt-Universität zu Berlin, a convite do colega Prof. Dr. Martin Eifert, com fomento do Deutscher Akademischer Austauschdienst - DAAD e no âmbito de minha licença para capacitação concedida pela UFRN. À direção editorial e à equipe revisora da EJJL, agradeço pela admissão do ensaio apesar da sua grande extensão, pela revisão final e pelo árduo e competente trabalho técnico-redacional. A todas as pessoas e instituições mencionadas meus mais sinceros agradecimentos pelas respectivas contribuições sem as quais essa primeira tentativa não teria sido trazida a relativamente bom termo.

2 Pós-doutor pelo Hans-Bredow-Institut (Pesquisa em Regulação da Comunicação Social) na Univ. de Hamburg, Alemanha, pelo Erich Pommer Institut (Direito e Economia da Com. Social) como Fellow da Fundação Alexander v. Humboldt (2010), e mais três vezes pela Humboldt-Universität zu Berlin; Professor Associado III na Universidade Federal do Rio Grande do Norte; Campus Universitário Lagoa Nova, Caixa postal 1524, 59078-970, Natal, Rio Grande do Norte, Brasil; leonardomartins1@yahoo.de
} 


\begin{abstract}
This is a case study preceded by a systematic explanation of its theoretical framework. The case is fictitious but strongly inspired by a judgement of the Federal Constitutional Court in Germany, in which the court assessed the constitutionality of a police measure and its judicial confirmation in the context of a counter-protest to a meeting that had occurred in a public space. For the case study's resolution, it was developed a juridical-constitutional opinion centred on the juridical situation exposed on the case, with the aim to evaluate the chances of a positive outcome of an eventual judicial action against the state measures (police measure and its juridical confirmation), considering the hypothesis of violation of the fundamental right to assembly. As in any other democracy, in Brazil under the Federal Constitution (FC) of 1988, the political-ideological contours of the right to freedom of assembly are as notorious as they are counterproductive - at least when one thinks of the indispensability of a specific constitutional legal technique. There is a deficit in the Brazilian literature that the present essay seeks to remedy in the light of comparative law considering the German case. To reconcile the democratic principle with the freedom of assembly, without a systematic approach, one assumes its instrumental character in relation to the former and does not meet the hermeneutical challenges implicit in the complex content of article 5, XVI, of the Brazilian Federal Constitution, in which freedom of assembly was enshrined. From a systematic analysis of the constitutional text, this study presents legal-dogmatic definitions that are methodologically disciplined, and analyzes the content of the aforementioned constitutional article, classifying its parts as either subjective conditions for the exercise of freedom of assembly or as implicit constitutional limits, which can be concretely drawn by the ordinary legislator, provided that they observe certain argumentative burdens. Thus, such a regulatory legislation could not, prima facie, be considered unconstitutional. Also, its eventual interpretation and application -as the interpretation of any other normative provision of administrative or criminal law in general - must be done in the light of freedom of assembly in such a way that the specific bounds between all three state functions are respected.
\end{abstract}

Keywords: Self-enforceability of fundamental rights. Regulation of the freedom of assembly. Constitutional limits of the freedom of assembly. Judicial interpretation in the light of the freedom of assembly.

\title{
Introdução
}

Uma obviedade do constitucionalismo tem sido relativizada em prol de interpretações e supostos métodos jurídico-hermenêuticos convenientes a possíveis arbitrariedades perpetradas por titulares de poder estatal constituído, nas esferas de competência das três funções clássicas: da legislativa, passando pela executivo-administrativa, chegando à judicial. Trata-se do pressuposto normativo por excelência do controle de constitucionalidade, que é a definição do parâmetro normativo constitucional contido em uma norma definidora de direito fundamental, no caso, no art. $5^{\circ}$, XVI CF acrescida de sua devida interpretação.

A aludida obviedade implícita na tarefa de qualquer constitucionalista é ainda mais ignorada em contextos sociopolíticos como o encontrado no Brasil contemporâneo. Correntes ideológicas alinhadas mais à esquerda tendem a enxergar os órgãos das polícias militares, responsáveis pela defesa do bem jurídico constitucional da segurança pública (art. 144 CF), com certa "desconfiança", para expressá-lo de maneira eufemística. ${ }^{3}$ Por sua vez, correntes ideológicas mais conservadoras ou à direita tendem a considerar o exercício concreto de direitos fundamentais que, em geral e por sua natureza, acarretem afetações de outros bens e interesses jurídicos coletivos e individuais como a

\footnotetext{
Entre as muitas manifestações na imprensa, v., por exemplo: Gerber (2016).
} 
estes submetidos, em uma indevida inversão da disposição hierárquica e do "ônus argumentativo" a restar mais bem explicitado ao cabo do presente ensaio. ${ }^{4}$

Ambos os polos marginais do espectro político-ideológico - excluindo-se de tais os absolutamente extremistas que não agem sob os auspícios da ordem constitucional vigente, mas ao contrário a combatem como a um inimigo ${ }^{5}$ - procuram legitimar seus posicionamentos em construções teóricas demasiadamente frágeis por não se encontrarem respaldadas no direito constitucional positivo. Destarte, perdem muito tempo e energia em construções teóricas estéreis.

O presente ensaio pretende, à luz de opções justeóricas, metodológicas e jurídico-dogmáticas bem delineadas, sobrepujar essa infrutífera dicotomia ideológica. Seus reconhecimentos centrais, sucintamente apresentados nos dois primeiros tópicos do ensaio, serão testados no derradeiro tópico à luz do método e do estilo redacional de parecer, tais quais desenvolvidos no direito constitucional alemão.

\section{Liberdade de reunião em face de seu caráter de parâmetro para o controle de constitucionalidade}

Interpretar qualquer direito fundamental é tarefa que deve ser iniciada não com as corriqueiras valorações abstratas do significado e do desenvolvimento histórico de seu processo de positivação. Isso vale especialmente no caso de um direito fundamental cujo exercício tenha consequências relevantes para a gestão do espaço público e sua compatibilização com bens jurídicos a ele contrapostos, como acontece com o exercício da liberdade de reunião. ${ }^{6}$ Pelo contrário, o início da

\footnotetext{
4 Do ponto de vista teórico-constitucional e, sobretudo, político-constitucional, é justamente a partir do incômodo causado por seu exercício a maiorias políticas que certos exercícios da liberdade geral carecem de proteção específica. É o caso de direitos fundamentais de comunicação social, por excelência, como o do art. 5 XVI CF. A respeito, v., por exemplo: Hufen (2016, p. 480 s.), que enfatiza o papel de proteção de minorias políticas e de oposições parlamentares que em tese as representam, além de sua "função de estabilização em face da integração de minorias no espectro de opiniões." A jurisprudência do TCF alemão vem enfatizando paulatinamente esse aspecto desde seu leading case "Brokdorf" (BVerfGE 69, 315), em que se tratava de uma reunião de manifestantes contrários à exploração da energia nuclear aprovada pelo Parlamento e implementada pelos competentes órgãos administrativos. Manssen (2016, p. 148) bem sintetiza esse desenvolvimento jurisprudencial ao sustentar que a proteção jusfundamental não deixa de ser eficaz somente porque por causa de dada reunião "chegou-se a limitar [o trânsito de] terceiros." Koll (2015, p. 15, 49) sintetiza precisamente do que se trata, na Alemanha, a partir de uma macroperspectiva: a liberdade em comento teria se tornado "parte da cultura política", sem embargo do comezinho reconhecimento de que "reuniões têm [por definição] efeitos externos." Quanto ao ônus argumentativo, que cabe sempre ao Estado e nunca ao titular do direito fundamental, v. a respeito de suas consequências para o exame Martins (2012a, p. 16 s., 28 ss.) e mais à frente, referências à nota 71. Sobre a Decisão Brokdorf, v. excertos e anotações no vernáculo de Martins (2005, p. 523-553). Todas as demais traduções das fontes em alemão que aparecem no texto e nas notas de rodapé são de responsabilidade do autor.

5 A respeito dessa difícil problemática que tangencia o conceito de democracia militante, v. a precisa síntese de Manssen (2016, p. 39): "A Grundgesetz [Constituição da RFA, a seguir: GG] reconhece o princípio da 'democracia militante' ('streitbare Demokratie') [...] O Estado deve ser capaz de se apresentar defensivamente contra os inimigos do sistema democrático e jurídico-legal." Em prol desse efeito, a GG positivou três instrumentos de reação: a proibição de associações (art. 9 II GG), a destituição de direitos fundamentais (art. 18 GG) e a proibição de partido político (art. 21 II GG), presentes pressupostos estritamente rigorosos.

6 A descrição da jornada histórica do processo de positivação de um direito fundamental em sistemas constitucionais ou internacionais de direitos humanos até pode ser profícua, a depender do desafio hermenêutico concreto. Porém, em geral, é supervalorizada na discussão pátria com abordagens muitas vezes superficiais e, por isso, contraproducentes. Descrição histórica em si é assunto da ciência humana, que é a História e não, necessariamente, da ciência social aplicada, que é o Direito.
} 
tarefa de interpretação, metodologicamente correta, ocorre com a análise do dispositivo constitucional como parâmetro do - e para o - controle de constitucionalidade.

Somente com tal abordagem direta do parâmetro, da medida ou régua do exame (Prüfungsmaßstab) de constitucionalidade, pode-se chegar a resultados significativos. Que todos os direitos fundamentais foram outorgados pelo constituinte com limites certos e determinados, ao menos determináveis, ora de maneira implícita, ora de maneira explícita, já se tornou um reconhecimento clichê, sem demérito de sua procedência justeórica e jurídico-dogmática. ${ }^{7}$ Contudo, começar a interpretação pela verificação dos limites do direito fundamental em tela, prosseguindo, de maneira concomitante, com uma ponderação entre o bem jurídico jusfundamental do art. $5^{\circ}$, XVI CF que, sabidamente, é dotado de supremacia normativa, e o bem jurídico que se apresenta como seu limite e que é, pelo menos potencialmente, constitucionalmente permitido, revela-se um erro grave metodológico que, infelizmente, é muito recorrente na literatura jurídica especializada ("doutrina") e na jurisprudência brasileiras. ${ }^{8}$

Por conta de tais equívocos da discussão pátria, necessário se faz esclarecer, antes de se adentrar a operação hermenêutica propriamente dita do art. $5^{\circ}$, XVI CF e de seus limites, com a máxima precisão possível, quais são os seus pressupostos teóricos. É o que se fará começando pela análise do contexto da demanda por uma discussão jurídico-constitucional propriamente dita, passando, então, pela apresentação sucinta das premissas teóricas, jurídico-dogmáticas e metodológicas do sistema escalonado do controle de constitucionalidade, especialmente no que se refere às diferenças estruturais entre os vínculos da instância legislativa, de um lado, e das instâncias executiva e jurisdicional, de outro. Por fim, define-se o papel do direito penal, em sua qualidade de produto do exercício de um poder constituído, como objeto do controle de constitucionalidade, por definição potencialmente inconstitucional, com base nos parâmetros jusfundamentais, em geral, e no parâmetro do art. $5^{\circ}$, XVI CF em especial.

\footnotetext{
Sobre o papel do cânone jurídico-hermenêutico histórico, que não deve ser confundido com o genético, e a prevalência dos cânones gramatical e sistemático sobre os demais cânones genético, histórico e teleológico, v. Schlink (1980).

7 Da literatura nacional citem-se, contemporaneamente: Sarlet (2017, p. 381-389) e Mendes (2017, p. 195-209). Da literatura nacional um pouco mais antiga, v. Mendes (2000, p. 223-241) e Steinmetz (2001, p. 33-37). Vide também: Pieroth et al. (2015, p. 67 s.) e, mais detalhadamente: Dimoulis e Martins (2014, p. 151-169).

8 Cf., na jurisprudência constitucional brasileira, a decisão do STF sobre a constitucionalidade da Lei de Biossegurança, cf. STF-ADI 3.510/DF, de 28 de maio de 2010 (Rel. Min. Ayres Britto). Ao invés de começar o exame com os parâmetros constitucionais potencialmente atingidos pela Lei que visava à proteção de relevantes questões bioéticas, abrangendo bens jurídico-constitucionais como a proteção da dignidade humana e o direito fundamental à vida, ambos potencialmente atingidos por exercícios dos direitos fundamentais à liberdade científica e à autodeterminação reprodutiva, o STF contrapôs imediatamente valores, bens, interesses e princípios entre si, em um sopesamento destituído de qualquer preocupação metodológica e jurídico-dogmática. Cf. a crítica e reconstrução do exame em Martins (2014).
} 


\subsection{Contexto da demanda por uma discussão jurídico-constitucional}

A referida ideologização do debate em torno dos problemas não apenas teóricos, mas especialmente dogmáticos e concretos surgidos em torno da interpretação e aplicação do art. $5^{\circ}$, XVI CF representa uma notória demanda por uma discussão jurídico-constitucional propriamente dita.

Essa demanda não vem sendo atendida pelas manifestações encontradas em várias publicações pátrias. Fala-se, por exemplo, genericamente, em luta pela democracia e por direitos, ${ }^{9}$ como se o direito fundamental tutelado por uma norma constitucional, que é sabidamente dotada de supremacia normativa, carecesse de tal defesa politicamente militante. Esse tipo de defesa faz sentido, sendo mesmo essencial, em períodos imediatamente subsequentes à promulgação de uma Constituição democrática, ${ }^{10}$ como teria sido o caso da defesa da Constituição Federal vigente a partir de 05 de outubro de 1988 até os primeiros anos da década de 1990, caso ela tivesse sido, então e seriamente, desafiada por forças políticas reacionárias. Trata-se, agora, e já com muito atraso, de se concretizar juridicamente a Constituição vigente, o que não se faz com defesas politicamente engajadas deste ou daquele dispositivo em que se positivaram os direitos fundamentais. Por outro lado, até mesmo exposições com pretensões um pouco mais técnicas ainda ficam aquém dos desafios hermenêuticos deduzidos da liberdade de reunião, tal qual positivada no sistema jusfundamental da CF, quando, sem mais, destacam, genericamente, sua suposta concorrência com a "liberdade de expressão". ${ }^{11}$

\footnotetext{
9 Nesse sentido, a seguinte bastante representativa manifestação de Silva (2017, p. 236): "Quanto mais o processo de democratização avança, mais o homem vai se libertando dos obstáculos que o constrangem, mais liberdade conquista." Em relação ao (vago) mérito da referida assertiva, não há como dela se discordar. Contudo, seu problema reside na sua baixa densidade jurídico-dogmática, deveras insuficiente para a solução dos muitos e multifacetários problemas jurídico-hermenêuticos pertinentes à aplicação do art. 5, XVI CF. Em que pese a grande contribuição da citada obra que alcançou, neste ano de 2017 , a louvável marca da $40^{a}$ edição, e tratar-se, na passagem citada, da genérica relação entre democracia e liberdade, não se ganha nada em termos de orientação no mundo jurídico da interpretação da CF com tais retóricas politizadas. Quanto menos se o ganha em um curso de direito constitucional positivo. No mais, a ideia de "processo de democratização", que parece pretender remeter o leitor à ideia emancipatória ("mais liberdade se conquista"), carece de definição e aproveitamento especificamente jurídico-hermenêuticos. As "liberdades juridicamente ordenadas" [POSCHER (2003)], rol em que se inclui a liberdade de reunião, são resultados do processo constituinte, positivados no sistema jusfundamental da CF. Não carecem, portanto, desse tipo de militância teórica e política. Os desafios ao intérprete deduzíveis da CF com vistas à viabilização teórica e jurídico-dogmática de sua força normativa são de natureza bem diversas, conforme se pretende demonstrar na presente contribuição.

10 Cf. Dimoulis e Martins (2014, p. 5).

11 Cf., por exemplo, a sucinta, mas, no geral, relativamente boa exposição de Branco (2014, p. 304-308). Além do aludido, o problema da exposição de Branco (2014, p. 306 s., grifo nosso) é não distinguir com suficiente precisão conceitual e metodológica, aqui perseguida, entre os elementos do suporte fático normativo e os dos limites da liberdade de reunião. É o que resta claro com uma leitura atenta da primeira oração com a qual abre o tópico dos limites: "A Constituição submete a liberdade de reunião a dois condicionantes expressos. Exige que o encontro não frustre outro, anteriormente convocado para o mesmo local, e impõe que seja dado prévio aviso a autoridade competente." Se forem condicionantes expressos o aviso prévio e a não frustração de outra reunião anteriormente convocada para o mesmo local, em que se constituiriam as expressões "pacificamente" e "sem armas", por ele alcunhadas de "elemento objetivo do conceito (do direito de reunião)" ? Classificar o modo permitido de reunião - que é uma questão preliminar à conclusão de tratar-se ou não de uma reunião protegida, ou seja, um modo de exercício a ser necessariamente seguido pelos reunidos, titulares do direito fundamental - como elemento objetivo não convence e conduz a uma mistura conceitual e metodológica. Embora se trate de um direito fundamental coletivo clássico (DIMOULIS; MARTINS, 2014, p. 56-58), ele é exercido por cada reunido que deve cumprir os requisitos prévios relativos ao modo pacífico e ao não porte de armas. Elemento objetivo do suporte fático é a presença ou não de uma reunião, como se verá na presente exposição (cf. já a seguir, no texto). De resto, no tratamento dos limites perpetrado por Branco (2014, p. 306 s.), ficou faltando tratar do possível traçado concreto dos limites, lá apenas abstratamente bem verificados, e das suas muitas consequências jurídico-constitucionais.
} 
Enquanto o debate limitar-se a tais "pregações" ou a análises ainda pouco refletidas teorica, metodologica e dogmaticamente, várias questões permanecerão sem resposta. Entre as muitas, mencionem-se a natureza jurídica, o modo de interpretação e a classificação jurídico-dogmática das aparentes cláusulas condicionantes para o exercício da liberdade de reunião, como é o caso da exigência de "prévio aviso a autoridade competente" a ser atendida pelos titulares do direito fundamental em tela.

Portanto, mister faz-se despedir-se de abordagens orientadas à mera defesa de opinião, com vistas à formação da opinião pública em geral, o que seria bastante salutar em seu fórum adequado. Em seu lugar, deve-se investigar o sentido normativo do direito fundamental do art. $5^{\circ}$, XVI CF com vistas a observar e, assim, a concretizar sua força normativa.

\subsection{Sistema escalonado do controle de constitucionalidade: premissas teóricas, jurídico- dogmáticas e metodológicas}

O sistema do controle de constitucionalidade é escalonado porque todos os poderes constituídos - desde o titular do poder constituinte derivado - são vinculados ao parâmetro jusfundamental, podendo, no exame, a lei ordinária figurar tanto como objeto do controle normativo quanto como parâmetro normativo dos atos de órgãos administrativos e jurisdicionais. A essa premissa teórica, devidamente combinada com outras, como os princípios constitucionais da separação (tripartição) funcional ${ }^{12}$ e o democrático, ${ }^{13}$ conecta-se a dogmática do vínculo de todo poder e de toda autoridade individualmente considerada ao direito fundamental.

As intervenções administrativas e judiciais no direito fundamental em pauta devem ser embasadas em lei autorizadora supostamente constitucional. ${ }^{14}$ Assim, metodologicamente, a interpretação deve ser iniciada pela norma em tese, prolatada pela instância legislativa ordinária, com vistas à verificação de sua compatibilidade abstrata com o parâmetro jusfundamental. Trata-se do objeto do controle de constitucionalidade potencialmente violador de uma ou mais normas constitucionais, notadamente de uma norma definidora de direito fundamental. Como os titulares de funções executivo-administrativas, materialmente, também legislam, deve-se atentar ao escalonamento do sistema normativo como um todo. Devem ser avaliados não apenas os aspectos formais relativos à competência e à observância dos procedimentos legiferantes, mas também as compatibilidades jurídico-materiais dos imperativos deônticos derivados das normas e atos infraconstitucionais com

\footnotetext{
12 Cf. a muito detalhada análise de Dimoulis (2008, p. 143 ss.).

13 Sobre a nem sempre harmoniosa relação entre o princípio democrático e a eficácia dos direitos fundamentais, enfatizando a antítese "complementaridade" contra "conflito": Dimoulis (2007, p. 200-214).

14 Um direito objetivo (codificado) de segurança e ordem públicas, ou "direito policial e de ordem (pública)" - em cujo sub-ramo administrativo insere-se o direito (objetivo) de reunião como capítulo específico daquele, tal qual desenvolvido na República Federal da Alemanha desde o século XIX - não dispensa um detido exame da autorização legal que embasa (Ermächtigungsgrundlage) a intervenção do poder de polícia estatal, incluindo sua constitucionalidade. Por muitos, v. Pieroth et al. (2016, p. 6-8, 36-41, 104 e passim).
} 
a norma-parâmetro. Isso implica uma tarefa muito mais árdua, quando não se queira - como aqui - politizar a interpretação do sistema normativo como um todo. Dogmática e métodos jurídicos cumprem exatamente essa função.

Por isso, a seguir, a atenção recairá sobre as peculiaridades da dicotomia "positivação de norma" (Rechtsetzung) versus interpretação \& aplicação de norma (Rechtsanwendung). ${ }^{15} \mathrm{~A}$ par dessa dicotomia nunca se deve perder de vista a diferença estrutural básica, com suas repercussões em termos de legitimidade normativa, entre o poder constituinte e os vários poderes constituídos. ${ }^{16}$

\subsubsection{Vínculo do poder constituído legislativo}

Tanto o legislador formal, como tal entendido aquele que é funcionalmente ligado ao Poder Legislativo do Estado, quanto o legislador material, que pode ser também o Executivo e, em casos muito pontuais, interna corporis, mas com eventuais repercussões gerais e abstratas, o Judiciário, são vinculados a todos os direitos fundamentais.

O exame desse vínculo ao art. $5^{\circ}$ XVI CF com vistas à verificação de sua observância pela instância competente tem como característica o estabelecimento de limites negativos para a configuração de regras estabelecidas no processo legislativo ordinário. Como qualquer titular de poder constituído legislativo, também o legislador formal ou material tem seus espaços de discricionariedade, ${ }^{17}$ cuja percepção, por sua vez, estabelece vínculo aos seus respectivos destinatários normativos (legalidade de atos administrativos, jurisdicionais e de particulares). Aliás, é desse contexto teórico que se deriva a diferença entre legalidade e constitucionalidade, não como antítese como querem ver muitos adeptos das já criticadas correntes, ${ }^{18}$ mas como processo de concretização escalonada de normas constitucionais.

A margem discricionária do legislador ordinário em face do parâmetro normativo-supremo do art. $5^{\circ}$, XVI CF é limitada, em primeiro lugar e sabidamente, por balizas puramente formais (competência do ente legiferante e observância do procedimento legislativo previsto para a aprovação de

\footnotetext{
15 Independentemente de qual órgão institucionalizado seja competente para a atividade legislativa de fixação de regras gerais e abstratas, essa é a principal diferença estrutural a marcar a racionalidade especificamente jurídica. Não se resume, portanto, a uma mera norma constitucional orgânica que revela a opção do constituinte por uma tripartição do poder. Cf. com mais referências: Dimoulis (2008, p. 143 ss.). No mais, v. a descrição da racionalidade especificamente jurídica em oposição a outras racionalidades, como a racionalidade política a partir de opções metodológicas claras e normativamente fundamentadas de Schlink (1980).

16 Daí a necessidade de se aperfeiçoar, cada vez mais, a dogmática do vínculo escalonado entre o poder constituinte e o poder legislativo ordinário e entre este e os demais poderes estatais e os particulares. Cf. neste sentido, na reconstrução da Decisão do STF sobre a constitucionalidade da Lei de Biossegurança (Lei n. 11.105/2005): Martins (2014, p. 141-177). Lá, tratou-se de um controle normativo abstrato. Contudo, caso a constitucionalidade do art. $5^{\circ}$ da referida Lei tivesse sido verificada, haver-se-ia, necessariamente, de se examinar a constitucionalidade de sua interpretação e aplicação pelos demais órgãos dos poderes constituídos Executivo e Judiciário.

17 Sobre a dogmática das margens discricionárias de todos os detentores de poder constituído, a começar pelo legislador ordinário, v. em geral: Silva (2011).

18 Dentre os principais defensores dessa falácia, que turva a compreensão do Estado Constitucional de direito, tem-se: Barroso (2005). Esse seu conhecido e diversas vezes republicado ensaio foi oportuna e devidamente contestado por Dimoulis (2008); uma contestação que, todavia, infelizmente, passados mais de oito anos, permanece ainda tão quanto observável sem resposta.
} 
lei), e por outras menos discutidas no direito pátrio que são as balizas formais-materiais, relativas à competência eventualmente aberta pelo constituinte para traçar limites concretos ao, por exemplo, regulamentar o exercício do direito fundamental. É o que o constituinte faz por intermédio da previsão das chamadas reservas legais simples e qualificadas ${ }^{19}$ e, finalmente, pelo critério material derivado do princípio da proporcionalidade, que tem seu lastro constitucional justamente no vínculo do legislador aos direitos fundamentais. Com efeito, mesmo que o constituinte tenha previsto limites ao direito fundamental outorgado a serem concretamente traçados pelo legislador formal, a percepção dessa possibilidade que, em alguns casos, pode-se revestir, igualmente, de ordem constitucional para legislar (mandado legislativo constitucional), ${ }^{20}$ deve atender a alguns requisitos constitucionais mínimos. $\bigcirc$ uso dessa competência, que abre ao mesmo legislador uma margem discricionária, deve se realizar com base não apenas no seu juízo de conveniência e oportunidade, mas deve atender também a critério normativo para se garantir o respeito à supremacia da norma jusfundamental e, com isso, ao vínculo da instância legislativa ordinária ao direito fundamental. ${ }^{21}$

No presente caso do vínculo do legislador ao direito fundamental garantido pelo art. $5^{\circ}$, XVI CF as balizas formais-materiais mencionadas ficam a cargo de bens jurídico-constitucionais potencialmente colidentes que, implicitamente, foram resguardados pelas locuções aparentemente condicionantes do exercício do direito fundamental, quais sejam: a não frustação de "outra reunião anteriormente convocada para o mesmo local" e a exigibilidade do "prévio aviso a autoridade competente". Considerando a dogmática do vínculo do legislador ao direito fundamental, ambas as ressalvas indicam que o legislador poderia - a partir de um exame seu de conveniência e oportunidade - regulamentar o exercício do direito em prol da proteção dos bens jurídico-constitucionais implícitos em tais ressalvas. Para o controle da observância pelo legislador do seu vínculo ao direito fundamental em tela, traz-se à pauta o controle da proporcionalidade de cada relação meio-fim estabelecida na regulamentação. ${ }^{22}$

\subsubsection{Vínculo dos poderes constituídos executivo e jurisdicional}

Obviamente, os titulares dos poderes constituídos executivo e jurisdicional são, também (mas não igualmente), vinculados ao direito fundamental em pauta, assim como a qualquer outro positivado no sistema jusfundamental pátrio. Para além do Executivo legislador e, como aludido,

\footnotetext{
19 Sobre os conceitos, cf. Dimoulis e Martins (2014, p. 154-163).

20 Um exemplo, por excelência, de um limite constitucional que não apenas abre uma margem discricionária para o legislador regulamentar o exercício mais amplo do direito e, na prática, legalmente definir o que deva ser um exercício abusivo de direito fundamental é a determinação de que a propriedade atenderá sua função social, no art. $5^{\circ}$, XXIII CF. Em razão do teor expressamente imperativo, não se trata apenas de uma reserva legal implícita, mas também de um mandado legislativo endereçado ao legislador civil. A respeito, cf. Martins (2012a, p. 180-210) e Martins (2016c).

21 Cf. Martins (2012a, p. 123) e Dimoulis e Martins (2014, p. 177).

22 Cf. Dimoulis e Martins (2014, p. 195-217).
} 
mais rara e pontualmente, do Judiciário legislador, ${ }^{23}$ esses poderes constituídos respondem por seu dever de interpretar e aplicar todo o direito infraconstitucional à luz do direito fundamental. Isso vale, especialmente, para o Judiciário, uma vez que a autonomia dos órgãos administrativos para descartar uma norma como inconstitucional - em outras palavras: para denegar-lhe aplicabilidade em razão da sua convicção da presença de incompatibilidade normativo-vertical com uma norma jusfundamental já ao plano normativo abstrato - é relativizada pelo princípio da legalidade e pelo sistema processual constitucional adotado no Brasil (art. 37, caput e 102 ss. CF). ${ }^{24}$ Pressupondo-se constitucional a lei aplicada pelo órgão administrativo ou, de outra feita, entendendo ele tratar-se de uma lei formal e materialmente constitucional, tão maior será sua autonomia para a percepção e imposição da específica eficácia da norma definidora de direito fundamental quanto mais ampla for a margem discricionária a ele deixada pela norma legal infraconstitucional.

\footnotetext{
23 O Judiciário deve legislar apenas para a organização interna dos negócios dos órgãos judicantes que o integram, vinculados, todavia, à legislação processual ordinária. No sistema hierárquico normativo, os Regimentos Internos são inferiores à legislação ordinária, não podendo inovar o direito processual, muito menos o material. Ocorre que esse reconhecimento elementar vem sendo contornado com argumentações na literatura especializada subservientes da jurisprudência do próprio STF e que, já por isso, são muito questionáveis. V., por exemplo, a tese da eficácia de lei ordinária do RI-STF defendida, entre outros, por Mendes (2004, p. 42) e Tavares (2006, p. 237). Cf., por outro lado, a crítica à manifestação daquilo que Dimoulis e Lunardi (2016, p. 256-265) com precisão alcunharam de "autocriação" (cf. Dimoulis e Lunardi, 2016, p. 264, com as referências também aqui citadas e outras). Tem-se avocado (referências: Dimoulis e Lunardi, 2016) um voto de um dos membros do STF que declarou o RI-STF recepcionado pela ordem constitucional em vigor com eficácia de lei ordinária a fim de se embasar a tese da recepção do RI-STF. Estranhamente, isso tem sido feito com expressa referência ao art. 115, 『único, c) da Constituição de 1967, segundo o qual: "O Regimento Interno estabelecerá [...] c) o processo e o julgamento dos feitos de sua competência originária ou de recurso." Primeiro, ocorre que o que se recepciona ou não são os aspectos materiais das normas pré-constitucionais. Nunca o serão os aspectos formais, dos quais se derivaria também o grau hierárquico da norma recepcionada. Segundo, o que se recepciona são apenas os objetos do controle da recepção e não as normas constitucionais, parâmetros não mais vigentes: no caso, o referido art. 115, § único, c) da CF/1967. Terceiro que, inobstante o mérito da correção ou incorreção da recepção julgada pelo citado membro da Corte, a mudança do parâmetro normativo-constitucional revela um consciente aperfeiçoamento da política constitucional perpetrado pelo constituinte originário de 1987/88. Portanto, até mesmo de constitutione ferenda o referido entendimento majoritário pode ser considerado um retrocesso incompatível com padrões mínimos de racionalidade jurídica.

24 Contudo, ao contrário de uma opinião por vezes defendida no Brasil, entre outros, por Mello (2007, p. 484-489) e Sundfeld (1990, p. 31), todos os atos administrativos podem ser revisados judicialmente, inclusive quanto ao seu mérito (binômio conveniência/oportunidade), ou seja, não apenas os ditos atos de "poder vinculado", mas também os atos de "poder discricionário". Tem-se aqui uma dicotomia terminológica que induz em erro ao se admitir - ou ao menos sugerir por intermédio dela - a possibilidade de existência de alguma espécie de poder estatal sujeito ao arbítrio de seu titular. Este simplesmente não existe, pelo menos normativo-constitucionalmente falando. Também não se pode reduzir o alcance e a potencial intensidade dessa competência revisional ao aspecto formal de amplo acesso à via jurisdicional garantida pelo art. $5^{\circ}$, XXXV CF. De fato, é observável a tendência de se admitir na literatura especializada brasileira com argumentações e rigores argumentativos os mais variados a tendência de não se excluir de plano os atos discricionários como faziam adeptos daqueles por Binenbojm (2014, p. 39) denominados "velhos paradigmas". Contudo, não basta substituir "velhos paradigmas" por exposições mal fundamentadas. Cf., exemplarmente, da extensa lista da literatura especializada, algumas manifestações mais bem arrazoadas: Binenbojm (2014, p. 40-41); Freitas (2007, p. 32, 45 s.); Freitas (2004, p. 69); França (2000, p. 136, 144 s.) e Cruz (1996, p. 367 s.); e outras que se limitam a assertivas tão vagas quanto a da suposta "superação de paradigmas": Baptista (2013, p. 231): o conceito de ato administrativo viabilizaria o seu controle judicial, pois que seria "o veículo de manifestação da autoridade administrativa"; Lima (2007, p. 223 s.) e Zancaner (1996, p. 25 s.). Para uma abrangente, muito analítica e bem refletida exposição, com esforços para refletir o estado da arte doutrinária e jurisprudencial no Brasil, também como aqui à luz do direito comparado alemão, v. Krell (2004). Não obstante, ocorre que, a despeito do efeito de irradiação da eficácia dos direitos fundamentais também sobre o direito administrativo e por causa do estrito vínculo da Administração Pública ao princípio da legalidade (art. 37, caput CF), além do monopólio do descarte normativo pelo Estado-juiz, somente este pode descartar norma eventualmente considerada inconstitucional pelo órgão administrativo (junto aos atos ditos "vinculados"). De resto, cabe ao mesmo órgão jurisdicional verificar se a interpretação legal implícita no ato administrativo "discricionário" observa o mandamento de interpretação orientada por direito fundamental.
} 
De qualquer modo, os atos administrativos em sentido amplo poderão ser sempre revisados pelo Judiciário, inclusive quanto aos méritos pertinentes às margens discricionárias administrativas. ${ }^{25}$ No que tange à competência para o exame da norma infraconstitucional em tese e sua interpretação e aplicação ao caso, à lide, há também de se diferenciar entre o atendimento a determinados pressupostos, normalmente descritos a partir da metáfora da "luz", do controle da norma em si, abstratamente considerada. Com efeito, todo o direito ordinário deve ser interpretado à luz dos direitos fundamentais: eis o resultado do desenvolvimento jurisprudencial constitucional alemão, no sentido de se concretizar uma essencial acepção do vínculo do Judiciário aos direitos fundamentais. ${ }^{26}$ Precisamente, tem-se um desenvolvimento que fora inaugurado na Decisão Lüth, do Tribunal Constitucional Federal alemão, ${ }^{27}$ amplamente recepcionada pela ciência e jurisprudência

\footnotetext{
25 Vide, novamente, a discussão e as referências da nota anterior. Algumas exposições como a de França (2000, p. 136-145), por exemplo, procuram - com elogiáveis esforços em prol da delimitação do mérito discricionário não passível de ser reformado pelo amplo controle judicial, como aqui defendido, por ausência de quaisquer vícios, caso em que se corre o risco, muito bem visto por ele, de se substituir "uma discricionariedade por outra." (FRANÇA, 2000, p. 144-145) - enxergar como sendo objetivo do controle judicial uma "restauração da legalidade pela invalidação judicial dos critérios de conveniência e oportunidade empregados pelo administrador" (ibid., p. 144). Segundo o mesmo autor, o controle judicial não se limitaria "à apreciação da legalidade exterior do ato administrativo." (FRANÇA, 2000, p. 136). A par da dubiedade da caracterização de "exterior" à legalidade, o compreensível problema dessa exposição composta em fins da década de 1990, mas ainda bem representativa do atual estado da arte da discussão jurídico-administrativa, é justamente a marginalização ou insciência do controle de constitucionalidade com base em parâmetros jusfundamentais na revisão judicial do mérito do ato administrativo. Se, de um lado, não se tem como anuir às juridicamente irracionais teses neoconstitucionalistas que insistem em opor, de modo a causar uma absolutamente inútil intriga conceitual, legalidade e constitucionalidade; por outro lado, o parâmetro legal é de fato o primeiro a ser atendido, mas não basta. Atos administrativos podem ser legais, porém seu parâmetro legal pode ser em si inconstitucional ou - mesmo sendo constitucional - pode ser potencialmente interpretado e aplicado ao arrepio dos parâmetros constitucionais que são destinados também ao momento da interpretação e aplicação. A revisibilidade judicial do ato administrativo como um todo - englobando o mérito administrativo se o parâmetro legal deixar à Administração Pública uma margem discricionária - tem, assim, três níveis. O primeiro nível é o mais óbvio da legalidade. O segundo nível - já ignorado por alguns - é o da constitucionalidade da norma legal, parâmetro do ato administrativo, independentemente de ter o legislador, em sua configuração, deixado ou não margem discricionária ao legislador material administrativo e/ou para a edição de atos administrativos com efeitos concretos. O terceiro nível - ignorado por muitos - é o da constitucionalidade do mérito do ato administrativo em si. Como a literatura jurídica especializada germânica atual e sistematicamente apresenta (estado da arte) (cf. Schmidt (2016, p. 109-126); Erbguth (2016, p. 256-262); Detterbeck (2016, p. 100-103); Hoffmann, Gerke e Hildebrandt (2016, p. 143-150); Bull e Mehde (2015, p. 256-262); Wienbracke (2015, p. 154-165); Sauerland (2015, p. 109114); Suckow e Weidemann (2014, p. 154-163); Peine (2014, p. 48-52); Maurer (2011, p. 148-151); Storr e Schröder (2010, p. 97-101); Schweickhardt e Vondung (2010, p. 60-65); Wallerath (2009, p. 233-241) e Stober e Kluth (2007, p. 326-329)), é neste nível que podem ocorrer erros no uso do mérito discricionário (Ermessensfehler), por omissão, insuficiência ou exagero nas decisões. A depender da situação concreta pode haver uma redução da abstratamente determinada margem discricionária, inclusive a zero (Ermessensreduzierung auf null), especialmente no âmbito do aqui mais importante direito policial e de segurança e ordem públicas. O que falta na dogmática administrativista pátria é a consciência de que a discricionariedade recai sobre a escolha da consequência jurídica ou sanção da norma, entre as alternativas por ela abertas, razão pela qual a vinculatividade ao seu suporte fático nunca se rompe. Esse é o exato motivo jurídico-dogmático para se despedir definitivamente da dicotomia poder vinculado versus poder discricionário: são referências extrajurídicas que, em regra, não previnem o abuso de poder. Entre tantas outras consultadas, a definição classificatória da seguinte muito influente autora revela a criticada insciência e carência de aprofundamento: "No ato vinculado, todos os elementos vêm definidos na lei; no ato discricionário, alguns elementos vêm definidos na lei, com precisão, e outros são deixados à decisão da Administração com mais ou menos liberdade de apreciação da oportunidade e conveniência." (DI PIETRO, 2011, p. 218). Isso é um simplismo insuficiente porque inidôneo a explicar o que juridicamente ocorre com a abertura das margens discricionárias em favor da Administração pelo legislador ordinário. A despeito de eventual uso de conceitos jurídicos indeterminados, a hipótese normativa, ao âmbito do suporte fático, é sempre claramente definida pelo menos na lei que seja compatível com os parâmetros de Estado de direito e constitucionais. $\mathrm{O}$ administrador não escolhe sua norma concreta aplicável a bel prazer, mas apenas entre alternativas relativas à consequência jurídica da presença da hipótese normativa (subsunção ao suporte fático). Cf., novamente, a corrente de fontes
} acima citada da literatura germânica.

26 Cf. com amplas referências Martins (2012a, p. 89, 100-119) e Dimoulis e Martins (2014, p. 95-114).

27 Cf. BVerfGE 7, 198 ss. Principais excertos e análises em: Dimoulis e Martins (2014, p. 259-274). 
constitucional brasileiras, inclusive por adeptos de correntes teóricas aqui refutadas. ${ }^{28} \mathrm{O}$ objeto do controle de constitucionalidade em Lüth não era uma norma em tese, mas a interpretação de norma do Código Civil alemão ( $\int 826$ BGB). Como amplamente comprova o ulterior desenvolvimento da jurisprudência constitucional daquele país ${ }^{29}$ devidamente acompanhada pela literatura jurídica especializada, também o direito público ${ }^{30}$ como um todo e, em especial, o direito penal devem passar pelo mesmo crivo. ${ }^{31}$

\subsection{Interpretação e aplicação do direito penal à luz do direito fundamental à liberdade de reunião}

Uma vez determinada a compatibilidade vertical (constitucionalidade abstrata) de norma infraconstitucional que foi aplicada a uma lide, procede-se ao controle de sua interpretação e aplicação pelo Estado-juiz. Por sua vez, estas devem ocorrer, como amplamente reconhecido e já aqui aludido, à luz do direito fundamental, no caso, do direito fundamental à liberdade de reunião.

Concretamente, isso significa que o Judiciário deverá exercer, tanto no plano da interpretação da norma infraconstitucional quanto da interpretação dos fatos controversos, sua função jurisdicional de maneira orientada pelo direito fundamental que é potencialmente atingido justamente por seu específico exercício de competência estatal jurisdicional. Trata-se de uma espécie de self restraint judicial desde a primeira instância, que não é apenas de bom alvitre ou auspicioso, mas que significa observância de seu vínculo normativo à norma jusfundamental. Como a Decisão Lüth e todo o desenvolvimento jurisprudencial e literário especializado posterior demonstrou, não são as partes processuais as imediatamente vinculadas a eventuais direitos fundamentais umas das outras, mas o exercício da função jurisdicional. $\bigcirc$ mesmo vale mutatis mutandis quando uma das partes processuais for o representante do Ministério Público legitimado a propor a cabível ação penal pública. ${ }^{32}$

28 Cf., por exemplo, a discussão em Barroso (2005, p. 16 s. e 26).

29 Da lista muito extensa, cf. as seguintes decisões: BVerfGE 25, 256 (Blinkfüer), excertos e análise em: Dimoulis e Martins (2014: 297-315); BVerfGE 89, 214 (Bürgschaft), excertos e análise em: Martins (2012a, p. 106-110) e BVerfGE 90, 27 (Parabolantenne), análise em: Martins (2012a, p. 103-106); BVerfGE 99, 185 (Scientology); e, mais recentemente, BVerfGE 119, 1 (Roman Esra). Sobre os dois últimos, vide excertos anotados em: Martins (2016a: 99 ss. e 106-114).

30 Cf. BVerfGE 73, 261 (269); 76, 143 (161) e Jarass (2011, p. 22).

31 Cf. por todos: Grimm (1995), que analisou decisão do TCF alcunhada de "Soldados são assassinos". A respeito da decisão, vide os excertos e anotações de Martins (2005, p. 414-427) e seu aperfeiçoamento em Martins (2017).

32 Por mais relevantes que sejam as atuações de todas as "funções essenciais à Administração da Justiça", de seu mero exercício, mediante, sobretudo, a proposição de uma ação, mesmo da ação penal pública, não deriva, pelo menos não em regra, uma intervenção em direito fundamental em sentido técnico-jurídico. Esta estará presente apenas com a publicação de uma decisão judicial condenatória, independentemente do trânsito em julgado. Isso porque, a despeito da evolução do conceito de intervenção (cf. Dimoulis e Martins (2014, p. 144 ss.)), deve estar presente, pelo menos, a característica da imperatividade da medida que se traduz em uma ordem jurídico-vinculativa. Apenas esta tem, efetivamente, o condão de reduzir a esfera jurídica de liberdade do atingido, pressuposto que está ausente nas medidas processuais propostas pelas funções essenciais à administração da Justiça. Bem diferenciado na análise desse pressuposto conceitual da intervenção, discorre a respeito Sachs (2016, p. 130-132). 
Assim, em havendo de se decidir uma ação penal quando o acusado tiver, ao menos aparentemente, exercido o direito fundamental à liberdade de reunião cujo alcance será mais bem definido na próxima seção, o juiz deverá, independentemente de provocação e a despeito de muitas normas processuais problemáticas do ponto de vista de um coerente ordenamento jurídico-processual constitucional, ${ }^{33}$ proceder a um exame trifásico de avaliação: do alcance do direito fundamental à liberdade de reunião; da intervenção estatal implícita na lei penal a ser interpretada e aplicada por ele e também implícita na sua própria interpretação e aplicação normativas; e, por fim, dos legítimos limites ao direito fundamental-parâmetro e das condições e pressupostos da aplicação destes.

A referida obrigatória autocontenção judicial restará inobservada se o juiz ignorar esse procedimento ou aplicá-lo erroneamente. Consequentemente, tal inobservância indica uma violação do direito fundamental em pauta que não fora perpetrada pelo legislador o qual prolatou a norma que serve de fundamento da causa de pedir, no caso, do Ministério Público ou de um particular em se tratando de processo civil. Em havendo inobservância dessa autocontenção judicial qualificada, a violação em tela teria sido perpetrada diretamente pelo órgão jurisdicional e, destarte, pelo Estado-juiz titular do poder constituído vinculado às determinações do poder constituinte, independentemente da não verificação da inconstitucionalidade abstrata da norma interpretada e aplicada.

\section{A positivação da liberdade de reunião como direito fundamental no art. $5^{\circ}, \mathrm{XVI}$ CF}

Apresentados os pressupostos justeóricos, jurídico-dogmáticos e metodológicos do exame de constitucionalidade com pauta em qualquer direito fundamental e, especialmente, no art. $5^{\circ}$, XVI CF tem-se de enfrentar a complexa positivação da liberdade de reunião como direito fundamental. Partindo-se do, aparentemente, muito diferenciado e completo teor do art. 5०, XVI CF o estudo envereda-se pela análise de sua dimensão jurídico-subjetiva, em oposição à sua mais frequentemente lembrada dimensão jurídico-objetiva, com seus típicos riscos axiológicos ${ }^{34}$ e de instrumentalização da liberdade, ${ }^{35}$ para, ao cabo, apresentar o contexto do sistema de limites do direito fundamental à liberdade de reunião.

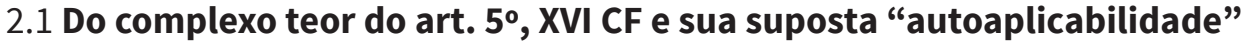

Muitos autores defendem que o art. 5, XVI CF seria "autoaplicável" no sentido não apenas de que poderia ser efetivamente exercido por seu titular sem nenhuma regulamentação, mas,

\footnotetext{
${ }_{33}$ Entre as quais, destaquem-se: a exigência com fundamento meramente sumular de a parte recorrente em sede de RE provocar o chamado prequestionamento; e a introdução do $\$ 3^{\circ}$ ao art. 102 CF pela EC 45/2004. V. a crítica em Dimoulis e Lunardi (2016, p. 325) e Martins (2010, p. 138-145).

34 Cf. com mais referências: Martins (2012a, p. 12-28).

35 Cf. Martins (2012a, p. 25-27): teoria "funcional-democrática" dos direitos fundamentais.
} 
especialmente, porque a proibiria, de plano. ${ }^{36}$ Os argumentos centrais de tais posicionamentos giram em torno de uma suposta suficiência de regras administrativas gerais, especificamente das cláusulas gerais disciplinadoras do poder de polícia. ${ }^{37}$ Em suas análises, essas manifestações omitem o grande impacto no exercício da liberdade de reunião que o cumprimento da missão constitucional de combater perigos ${ }^{38}$ abstratos, concretos, objetivos, subjetivos, diretos ou indiretos por parte dos agentes públicos que exercem o poder de polícia. A começar pelo comezinho fato de que uma reunião, independentemente da tutela constitucional, pode representar uma ameaça, no mínimo à segurança pública, ou ser ela própria o bem jurídico vulnerável, que por isso demande proteção pelos mesmos agentes públicos detentores do poder de polícia. ${ }^{39}$

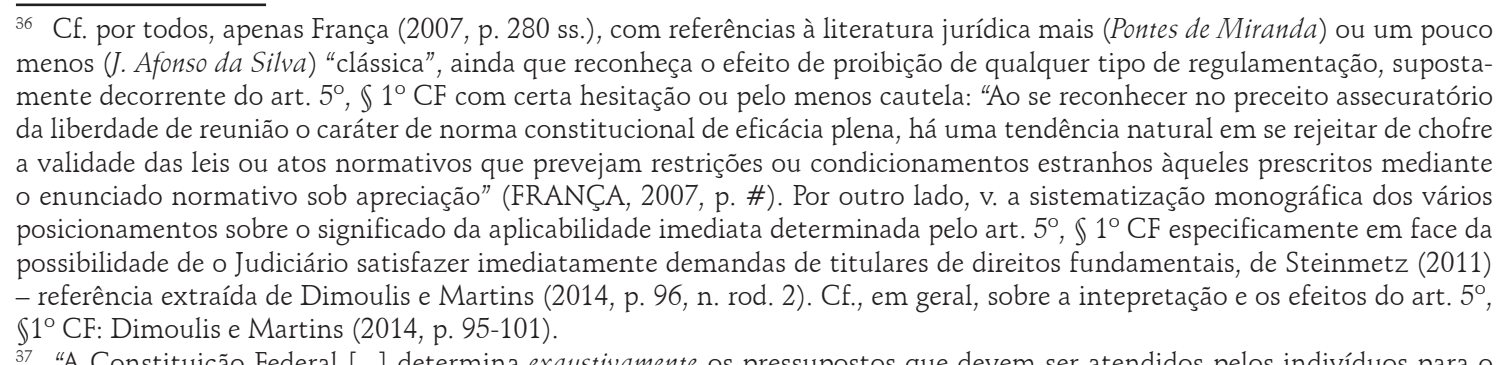
37 "A Constituição Federal [...] determina exaustivamente os pressupostos que devem ser atendidos pelos indivíduos para o vérbio em destaque. Se a CF determina, e de maneira exaustiva, os pressupostos do exercício do direito a serem "atendidos pelos indivíduos", caberia à Administração segundo esse entendimento apenas respeitar o direito na medida em que teria competência tão somente para fiscalizar o cumprimento dos mencionados pressupostos "para o [seu] exercício". Essa linha de pensamento majoritária, mas lastreada na absolutamente impertinente e equivocada teoria das eficácias diferenciadas (SILVA, 2004) das normas definidoras de direitos fundamentais em face do art. $5^{\circ}, \$ 1^{\circ} \mathrm{CF}$, o qual de maneira uníssona determina igual eficácia para todas as referidas normas constitucionais, aplicada à interpretação do art. $5^{\circ}$, XVI CF ignora, entre outros, os dois problemas seguintes [cf. a crítica, ainda que a partir de pressupostos teóricos não partilhados aqui, de SILVA (2006, p. 24, 45 ss.)]. Primeiro, tendo em vista apenas a dogmática administrativista, seria possível entender que se trataria, então, de expressão de "poder vinculado" e não "discricionário" como a caracterização da disciplina constitucional como exaustiva parece sugerir? Haveria como conciliar a função de resistência (ou de defesa) do direito fundamental em face de intervenções estatais que são, no caso, justamente administrativas, com o poder discricionário dos órgãos administrativos, suposta ou normativamente competentes? Se se tratar de poder vinculado, como conciliar a capacidade funcional dos órgãos administrativos com o direito fundamental parâmetro em tela, considerando a proteção de bens jurídico-constitucionais colidentes que representem limites àquele? Em ambos os casos, qual seria a extensão do cabível controle judicial de medidas administrativas "fiscalizadoras" do exercício legítimo porque cumpridor dos supostamente taxativos e claros pressupostos estabelecidos pelo constituinte? O segundo problema, este especificamente de dogmática constitucional, refere-se à própria essência do vínculo escalonado das três funções clássicas ao direito fundamental. Em sendo direito de resistência (ou "de defesa"), valendo-se de conhecida metáfora, como mirar o "canhão" do direito fundamental contra medidas interventivas provenientes do Legislativo, Executivo e Judiciário se se traz ao suporte fático da norma jusfundamental, em primeiro e principal plano, o comportamento do titular do direito fundamental e não o dos órgãos estatais? Quem preenche os elementos do suporte fático de uma norma jusfundamental são os órgãos estatais com suas medidas interventivas e não o titular do direito fundamental. A CF, como qualquer Constituição do tipo ocidental democrático é, antes de tudo, uma Constituição das "liberdades juridicamente ordenadas" (POSCHER, 2003) e não locus normativo para prescrição de condutas a particulares, que é pauta de todo o direito infraconstitucional por excelência. Toda ordem de fazer inserida no Texto Constitucional, mesmo as que soem como obrigações impostas a particulares, como, por exemplo, a determinação de que o racismo e outras condutas constituem crimes (art. $5^{\circ}$, XLII CF), são direcionadas diretamente, primeiro, ao Estado legislador e, depois, às demais funções no âmbito de suas competências e atribuições. Na melhor das hipóteses em termos de não restrição aos poderes constituídos, há exclusões de condutas da área de proteção do direito fundamental que implicam suas respectivas retiradas do suporte fático cujo preenchimento pelos poderes constituídos leva, em regra, à sanção da nulidade do ato, salvo causas excludentes da inconstitucionalidade verificáveis a partir da dogmática dos limites aos direitos fundamentais.

${ }_{38}$ O combate a perigos sintetiza, por excelência, a tarefa do poder de polícia do Estado, notadamente dos órgãos competentes funcionalmente ligados ao Poder Executivo. Cf. a descrição do conceito e as classificações aludidas de Pieroth et al. (2016, p. 60-80).

39 Cf. Pieroth et al. (2016, p. 355-357), que descrevem essa potencial dupla característica de uma reunião de ser, de um lado, potencialmente perturbadora da segurança pública; ou, de outro lado, potencialmente sujeita a agressões, ensejando o dever 
"Autoaplicabilidade", no primeiro sentido mencionado, é de fato determinada constitucionalmente pelo art. $5^{\circ}, \$ 1^{\circ} \mathrm{CF}$ com seu uníssono teor. Contudo, dele não se deriva, em absoluto, o segundo sentido de vedação de toda e qualquer regulamentação. Isso porque, no cumprimento de sua tarefa de harmonizar exercícios de liberdade incompatíveis entre si, ou de harmonizar o exercício da liberdade com a garantia da capacidade funcional de órgão estatal em prol da proteção de bens coletivos e mais ou menos vulneráveis, o Estado legislador tangencia, de maneira incontornável, aquilo que, na dogmática jusfundamental, convencionou-se chamar de área de proteção normativa. ${ }^{40}$ Considerar violação todo e qualquer "tangenciamento" ou mesmo a ocorrência de intervenção estatal na área de proteção do direito fundamental - como conceito técnico-jurídico inarredável para a verificação de uma possível violação após a aplicação jusfundamentalmente orientada dos limites implícitos ou explícitos previstos pelo constituinte ao estabelecer a ordem constitucional vigente no Estado brasileiro - seria muito mais do que temerário. Implicaria uma notória usurpação da função legislativa e das prerrogativas constitucionais do legislador ordinário a ela inerentes. ${ }^{41}$

No entanto, ao contrário da referida opinião defensora da tese de que o teor do dispositivo bastaria à solução prévia de quaisquer conflitos que se apresentem, as aparentes cláusulas condicionantes não têm como serem todas entendidas da mesma forma.

De um lado, segundo o teor do início do dispositivo: "todos podem reunir-se pacificamente, sem armas". Indubitavelmente, tem-se aqui uma condicionante destinada, exclusivamente, a cada titular do direito fundamental. Reunidos ${ }^{42}$ que não estejam exercendo o comportamento contemplado pela norma de modo pacífico ou que estejam portando armas não poderão reivindicar jurídico-processualmente, pelo menos não com chances de êxito ${ }^{43}$ o livre exercício do direito fundamental em pauta.

Por outro lado, as demais locuções, aparentes condicionantes, são de natureza diversa da primeira, por não se conectarem com um modo permitido de exercício da liberdade, o qual seja ime-

de uma específica proteção do Estado. Cf. o título do tópico escolhido pelos ora citados autores: "Direito de reunião como direito de combate a perigos".

40 Cf. Dimoulis e Martins (2014, p. 129 ss.).

41 Todos os três poderes constituídos foram dotados constitucionalmente de necessárias margens discricionárias para o cumprimento de suas funções constitucionais. Cf., por todos, em relação especificamente à discricionariedade legislativa na discussão pátria, em geral: Silva (2011).

42 Pela natureza do direito fundamental em tela ser explicitada no decorrer do texto, principalmente por se tratar do uso do corpo por pessoas naturais para, na imensa maioria dos casos, a apresentação de uma opinião dos reunidos interdependentes, o caráter artificial da pessoa física é incompatível com a essência da liberdade de reunião. $O$ teor restritivo, a despeito de muitas infundadas tentativas de ampliá-lo, exclui os estrangeiros não residentes da tutela em face do legislador pelo menos (explicações sobre as consequências jurídico-dogmáticas dessa exclusão e referências em Dimoulis e Martins (2014, p. 73-78). Quanto à possibilidade de pessoas jurídicas serem titulares da liberdade de reunião, no sistema alemão, não na qualidade de participantes, mas de realizadoras ou organizadoras, posições que são contempladas na Lei Federal de Reuniões com direitos e obrigações diretas: Schulze-Fielitz (2013: 1048) e Höfling (2014: 445).

43 Por vezes, difunde-se uma consequência equivocada do princípio da inafastabilidade e indeclinabilidade do exercício da função judicial, uma vez devidamente provocado (non liquet), principalmente no âmbito do direito público, especificamente do direito social. Ocorre que a indeclinabilidade nada garante em termos de êxito de uma movida ação judicial. Assim, em não havendo fundamento legal e/ou constitucional para um determinado pedido, a prestação jurisdicional devida é seu indeferimento por ausência de amparo legal ou constitucional. De resto, non liquet (do lat.: "não há clareza") é um princípio pertinente à dogmática do ônus da prova em matéria jurídico-processual. Por isso, não serve de panaceia a legitimar um abusivo "ativismo judicial", que poderia ser, de maneira mais precisa, alcunhado de "decisionismo judicial". 
diata e facilmente aferível pelo titular. Todos podem reunir-se "(...) em locais abertos ao público". Seria indicada uma interpretação e contrario de que o direito de reunião não se estenderia a reuniões realizadas em locais "fechados ao público"?

No mesmo sentido jurídico-dogmático distinto da primeira condicionante cujo destinatário exclusivo são os titulares da liberdade, devem ser entendidas e classificadas as demais locuções do dispositivo:

Todos podem reunir-se "independentemente de autorização, desde que não frustrem outra reunião anteriormente convocada para o mesmo local". Aqui a locução "independentemente de autorização", que poderia ser mais uma locução supérflua da CF, porque sem sentido normativo próprio, ${ }^{44}$ ganha relevo com a imediatamente seguinte locução adverbial, "desde que não frustrem outra reunião anteriormente convocada para o mesmo local". Em tese e a contrario sensu, o poder público poderia desautorizar (previamente? Ou dissolvê-la ad hoc durante seu transcurso?), dito de forma positiva: proibir uma reunião, cujos integrantes não tenham cumprido a condicionante negativa da não frustração de outra reunião anteriormente convocada para o mesmo local?

A última locução, qual seja: "sendo apenas exigido prévio aviso a autoridade competente", não elide esse reconhecimento; pelo contrário, confirma-o, revelando que se trata de autorização pelo constituinte para a determinação de limites e não condicionantes apriorísticas para um legítimo exercício do direito fundamental destinadas aos seus titulares. ${ }^{45} \mathrm{E}$ limites a direitos fundamentais não podem prescindir da instância legislativa. Ou: qual deveria ser o poder constituído, funcional e democraticamente legitimado, a determinar quem deva ser a "autoridade competente" para gerenciar o uso de "locais abertos ao público" por manifestantes das mais diversas predileções ideológicas, por exemplo? Deveria ser o governante ou o gestor ou o órgão policial de plantão? Sem organização e procedimento, não há como se autorizar limites constitucionalmente legítimos ao exercício do direito fundamental em pauta. ${ }^{46}$ Quem deveria determinar tal organização e procedimento, quais seriam os prazos e critérios para a delimitação dos espaços a serem utilizados?

Outros questionamentos bem mais concretos como os seguintes veem pauta. A partir de que momento uma reunião deveria ser considerada convocada para efeitos de se aferir a anterioridade de sua convocação em relação a outras que potencialmente disputem os mesmos espaços? Convocada por intermédio de que veículo de comunicação social? Por quem? Seriam desnecessárias

\footnotetext{
${ }_{44}$ Claro que se deve sempre partir da presunção de que nenhuma palavra de texto normativo seja gratuita. Porém, o resultado da interpretação pode ser a verificação de uma redundância normativa. Outro exemplo é a reiteração, no caput do art. $5^{\circ} \mathrm{CF}$, da igualdade perante a lei, evidente na expressão que se segue a "Todos são iguais perante a lei", qual seja: "sem distinção de qualquer natureza".

${ }_{5}$ Cf. as análises trazidas anteriormente na nota 37 em torno do suporte fático das normas definidoras de direito fundamental e suas consequências para as classificações dogmáticas dos elementos a serem enfrentados no exame específico de constitucionalidade de medidas provenientes de quaisquer poderes constituídos, respeitadas a lógica hierárquica escalonada e o princípio distributivo do ônus argumentativo. Quanto ao último, v. Martins (2012a, p. 28-43).

46 Claro que a legitimidade passa pela determinação de organização e procedimento que garantam que as medidas interventivas autorizadas sejam neutras em face dos embates de opinião ou ideológicos. Cf. Pieroth et al. (2015, p. 202 ss.). Em geral, sobre a conveniência da organização e procedimento que como já visto também decorre da dimensão jurídico-objetiva do direito fundamental: Martins (2012b) e, aquiescentes: Dimoulis e Lunardi (2017, p. 12 s.).
} 
as definições de figuras como a do organizador e a do líder com respectivos direitos e obrigações? Qual pode ser a extensão territorial do que se entende por "mesmo local"? A partir de qual momento e como caracterizar o que seja "frustrar" outra reunião anteriormente convocada para o mesmo local? Pode uma reunião para a qual se espera um público de poucas dezenas ou centenas de pessoas bloquear o uso de um determinado espaço aberto ao público, eventualmente com características simbólicas, em relação a outra para a qual se espera um público composto de várias dezenas, quiçá centenas de milhares de pessoas porque o organizador da primeira convocada via internet foi mais ágil do que os muitos organizadores e potenciais líderes da segunda? Como agir diante de reuniões sem organizadores ou lideranças fixas ou predefinidas? Como proceder em relação às reuniões cujo propósito tenha lastro em um determinado acontecimento muito próximo? Restariam reuniões espontâneas prejudicadas? Como disciplinar as peculiaridades das reuniões convocadas para um local aberto ao público em relação àquelas que se deslocam por vias públicas (passeatas ou marchas)?

Deveria ser confiada a concretização de tais limites constitucionais às citadas autoridades executivas? Já o princípio do Estado de direito, em suas especiais derivações da certeza e segurança jurídicas, restaria comprometido se esse entendimento prosperasse.

As especificidades que devem ser observadas pelo intérprete do direito constitucional e pelo Estado-juiz no sentido de se garantir o respeito de seu vínculo ao direito fundamental à liberdade de reunião no sentido exposto serão mais bem aprofundadas adiante e ilustradas na solução do caso concreto. Antes, porém, cabe um último esclarecimento justeórico com fortes implicações jurídico-dogmáticas a respeito da bidimensionalidade do direito fundamental à liberdade de reunião do art. $5^{\circ}$, XVI CF.

\subsection{Bidimensionalidade dos direitos fundamentais e a dimensão jurídico-subjetiva da liberdade de reunião}

\subsubsection{Dicotomia dimensão subjetiva versus objetiva dos direitos fundamentais e a superioridade lógica e dogmática da primeira}

A bidimensionalidade epigrafada vem sendo pesquisada na teoria geral dos direitos fundamentais há pelo menos cinco décadas. A historiografia da discussão remonta à já citada Decisão Lüth (1958) e a suas consequências. ${ }^{47}$ Outro marco jurisprudencial muito relevante na percepção de que as normas definidoras de direitos fundamentais podem ser vistas pelo viés jurídico-objetivo ou jurídico-subjetivo é a primeira decisão do TCF alemão sobre a constitucionalidade da criminalização do aborto. ${ }^{48}$ Nela, derivou-se da dimensão objetiva, inclusive, um dever estatal de tutela cuja obser-

\footnotetext{
47 A discussão experimentou seu último apogeu no início da década de 1990. Cf., por exemplo, Böckenförde (1990) e Alexy (1990). Trata-se de dois ensaios que abrem a primeira edição da década de 1990 do renomado periódico "Der Staat".

48 BVerfGE 39, 1. Cf. a introdução a essa dogmática, além dos excertos da decisão e anotações de Martins (2016a, p. 175-181). Cf., na sequência em Martins (2016a, p. 181-195), os excertos e anotações sobre a segunda decisão sobre a constitucionalidade
} 
vância implicaria, segundo aquele tribunal, até mesmo um dever de criminalização de conduta. Por intermédio dessa decisão, restringiu-se, de maneira inédita, a competência discricionária do legislador penal em livremente escolher com base em seus critérios pautados no mandato popular quais bens jurídicos devam ser protegidos com o uso da cominação penal de condutas. ${ }^{49}$

O TCF alemão sempre enfatizou, desde a referida Lüth, que os direitos fundamentais seriam, em primeira linha, direitos público-subjetivos, como tal encerrando, sobretudo, pretensões à abstenção de medidas estatais interventivas nas esferas de liberdade garantidas jusfundamentalmente (direito de resistência - status negativus; a prestações - status positivus; ou a participação nos negócios do Estado - status activus). ${ }^{50}$ A dimensão jurídico-objetiva seria apenas a outra face da mesma moeda. Trata-se de proteger os bens jurídicos em si contemplados pela outorga de direito fundamental, independentemente da percepção por seus titulares. ${ }^{51}$

Ocorre que a construção da dimensão jurídico-objetiva é suscetível a teorias sobre os direitos fundamentais dotadas de fundamentos, até mesmo fundamentos jusfilosóficos, que são questionáveis quando contrapostos aos diversos sistemas normativos decorrentes de expressões de poder constituinte originário lastreados na tradição ocidental democrática. Ora entendidos como valores hierarquicamente dispostos no Texto Constitucional, ora como instituições, ora como instrumentos da realização do processo democrático em si, ora como princípios formais determinadores de uma otimização a ser feita com processos ponderativos não controláveis racional e metodologicamente, ${ }^{52}$ a abordagem mais engajada dessa dimensão não tem o condão de relativizar a superioridade lógica e jurídico-dogmática da dimensão jurídico-subjetiva. Para além do reconhecimento - quase ritualístico - da proeminência da dimensão subjetiva por parte do TCF alemão, soando por vezes pouco substancial em face do seu teor quase confessional, é a dimensão subjetiva que, diretamente, corresponde aos específicos vínculos às normas definidoras de direitos fundamentais mediante imposição de restrições aos poderes constituídos.

Como efeitos específicos da dimensão objetiva da liberdade de reunião, a literatura jurídica especializada alemã elenca, em geral, os seguintes: ${ }^{53}$ dever estatal de tutela perante particulares, organização e procedimento (na cooperação dos órgãos de segurança pública com os organizadores e lideranças das reuniões) e eficácia de irradiação principalmente sobre o direito civil e penal.

\footnotetext{
da criminalização do aborto (BVerfGE 88, 203).

49 Cf. a precisa análise dos modos de cumprimento do dever estatal de tutela, e já muito crítico em relação aos deveres de criminalização, de Bumke (1998, p. 75 ss.). Mais recentemente, cf. Oliveira (2013) e Dimoulis (2016, p. 95 ss., 99-103).

50 Cf. Dimoulis e Martins (2014, p. 49-54).

51 Cf. Dimoulis e Martins (2014, p. 117-120). No vernáculo, cf. a exposição monográfica dotada de um grande engajamento teórico sem deixar de refletir sobre as implicações práticas e judiciais de Nascimento (2016).

52 Descrição e crítica em Martins (2012a, 12 ss., 65 ss.).

53 Cf. Schulze-Fielitz (2013, p. 1069-1075). De maneira muito correta e consequente, em seus comentários ao art. 8 GG, Schulze-Fielitz (2013, p. 1071 s.) destaca a não derivação de direito à participação em reuniões com fulcro em subsídios estatais para a realização de reuniões. Despiciendo alertar sobre uma possível subversão do direito fundamental: de um potencial crítico poderia se transformar em instrumento de cooptação da sociedade civil e proselitismo oficial, tão típico de regimes político-governamentais autoritários, que não têm nenhum pejo em ostentar alcunhas como "democrático".
} 


\subsubsection{Riscos da supervalorização da dimensão jurídico-objetiva}

A equiparação entre as duas dimensões ou - pior - a supervalorização da dimensão jurídico-objetiva acarreta sérios riscos à realização do programa normativo-constitucional no âmbito dos direitos fundamentais. Para o direito fundamental à liberdade de reunião, o risco é bastante significativo.

A começar pela tentação em aplicar o direito fundamental em tela combinado com o princípio democrático, considerando o sempre enfatizado caráter instrumental dos direitos fundamentais de comunicação social em relação àquele. Combinar normas jusfundamentais com o princípio constitucional objetivo, que é o princípio democrático, tem efeito, em geral, contrário à tutela daquilo que é proeminente no direito fundamental: a possibilidade de seu livre e totalmente desimpedido ou curatelado exercício. Democracia pode ser realizada pelo exercício de direitos fundamentais. Porém, eles podem se encontrar em polos normativos contrapostos, uma vez que a tutela jusfundamental tem por sentido primeiro a proteção de direitos individuais não transacionáveis dentro do processo legislativo ordinário que, por sua vez, é sustentado pelo princípio constitucional democrático. Uma materialização do conceito do princípio democrático, fazendo-o abarcar os interesses e direitos das minorias políticas que não logram impor seus interesses no processo legislativo, representa tão somente um elemento justeórico e jusfilosófico bastante infrutífero, dogmatica e praticamente falando.

No mais, a ênfase exagerada na dimensão objetiva pode ter o condão de comprometer a neutralidade ética do Estado, na medida em que outra tentação - tão inevitável quanto a primeira mencionada, porém muito mais nociva - é a da valoração não apenas abstrata da liberdade de reunião em face de seu caráter instrumental para a democracia, mas a valoração concreta do propósito de uma dada reunião, vale dizer, das opiniões políticas nela defendidas.

Por fim, tanto a equiparação quanto a supervalorização da dimensão objetiva ofusca o papel da liberdade de reunião em sua acepção de direito ao livre desenvolvimento coletivo da personalidade, o que resta evidente já na própria definição do conceito de reunião, notadamente na determinação de um conceito estrito de reunião que, como se verá, desprestigia aquelas reuniões nas quais não se persegue o propósito de defender uma opinião partícipe (do), concorrente no processo de formação da opinião pública. ${ }^{54}$

54 Cf. Michael e Morlok (2016, p. 161), sob a significativa epígrafe: "Participação comunitária como elemento marcante da comunicação." 


\subsubsection{Configuração infraconstitucional do direito fundamental pelo legislador e seu possível resultado do direito objetivo de reunião como sub-ramo autônomo do direito administrativo}

Do debate em torno da fundamentação e das consequências da dimensão jurídico-objetiva do direito fundamental à liberdade de reunião, há de ser apartada a discussão sobre as possibilidades de o legislador ordinário configurar, ao nível infraconstitucional, a área de proteção do direito fundamental. Tudo que o legislador normatizar que incida sobre o fenômeno social das reuniões será uma potencial intervenção estatal na área de proteção e, assim, potencialmente inconstitucional. Todavia, a inconstitucionalidade apenas será aferida após a aplicação dos limites constitucionais e a verificação da inobservância dos critérios constitucionais especificamente previstos pelo poder constituído vinculado. Nada obstante, nem toda legislação que trate de reuniões será intervenção no sentido técnico-jurídico constitucional. Como ocorre em face de vários direitos fundamentais, o legislador pode expandir as possibilidades e os modos de exercício do direito fundamental, ${ }^{55}$ atuando como colaborador da liberdade negativa e não, necessariamente, como seu oponente.

Uma atuação legislativa nesse sentido colaborativo pode até ser motivada por uma percepção jurídico-objetiva do direito fundamental, razão pela qual convém tratar dela no presente tópico. Todavia, a configuração, conformação ou concretização infraconstitucional do direito pelo órgão legislativo não se confunde com uma forma de expressão da dimensão jurídico-objetiva. Há uma extensa literatura especializada perscrutando os fundamentos e consequências da configuração de direitos fundamentais pelo Legislativo. ${ }^{56}$ Isso porque há direitos fundamentais que, a despeito do art. $5^{\circ}, \mathbb{S} 1^{\circ} \mathrm{CF}$ não prescindem de um mínimo de regulamentação, pois têm áreas de proteção marcadas normativamente. ${ }^{57}$ Não é o caso da liberdade de reunião que, de fato, prescinde, materialmente, de qualquer regulamentação para poder ser exercitada por seus titulares. Os problemas ocorrem apenas por ocasião do comprometimento de outros bens jurídicos mediante seu exercício, ou seja, começam quando da investigação de seus limites constitucionais.

Independentemente dessa prescindibilidade, questionável é se não seria, mesmo sem o dever de legislar, de bom alvitre (juízo de conveniência e oportunidade, de lege ferenda, portanto) que o legislador criasse as bases de um direito objetivo de reunião. No quadro de sua estrutura normativa geral, esse direito objetivo de reunião seria pertinente ao direito público, mais especificamente ao direito administrativo. Esse questionamento não tem como ser aprofundado aqui. Basta, no entanto, uma referência ao complexo teor do dispositivo do art. $5^{\circ}$, XVI CF e ao seu entorno jurídico-constitucional para se chegar à recomendação urgente de um marco regulatório que seja idôneo a trazer certeza jurídica aos diversos atores sociais, aos titulares do direito fundamental e às

\footnotetext{
55 Cf. Dimoulis e Martins (2014, p. 152 s.).

56 Cf., por exemplo: Bumke (2009) e Cornils (2005).

57 Cf. Pieroth et al. (2015, p. 60 ss.).
} 
autoridades vinculadas. Seu resultado deveria, então, passar no controle de constitucionalidade, tendo de ser, entretanto, separadas, no bojo do marco regulatório, as normas intervenientes das normas meramente configuradoras de conteúdo; estas últimas cuja constitucionalidade não poderia mais ser questionada, pelo menos não em face do parâmetro específico do art. $5^{\circ}$, XVI CF.

\subsection{Do texto constitucional ao contexto (sistema) normativo-jusfundamental}

Assim, em apertada síntese, o que se deriva jurídico-dogmaticamente da norma definidora do direito fundamental à liberdade de reunião, do art. 5, XVI CF é o seguinte:

\subsubsection{Suporte fático da norma jusfundamental}

Como os direitos fundamentais outorgados pelo constituinte representam um sistema de proteção de liberdades com pretensão de ser livre de lacunas, define-se seu suporte fático negativa e positivamente. No primeiro caso, tem-se a exclusão de condutas que fazem parte da área da vida ou área de regulamentação que o constituinte consciente e expressamente não protegeu. No segundo caso da definição positiva, verifica-se o alcance do recorte protegido. Antes, porém, necessário se faz descrever e definir o âmbito da vida social contemplado pela norma jusfundamental cujo ponto de partida é um conceito correspondente a apenas um ou a um complexo de bens jurídicos.

\subsubsection{1 Área da vida social: conceito de reunião}

O texto da norma em tela é, conforme aludido, de fato, complexo. Dele depreende-se, primeiro, a área da vida social sobre a qual incide a norma constitucional, também alcunhada de área de regulamentação (em sentido amplíssimo, sinônimo de área de normatização lato sensu). ${ }^{58}$

No que tange à primeira parte do dispositivo, segundo o qual: "todos podem reunir-se pacificamente, sem armas [...]", tem-se de definir, antes de se interpretar a condicionante do caráter pacífico e de se perscrutar o conceito de armas, o núcleo semântico da tutela, isto é, o aspecto geral do direito de liberdade sobre o qual repousa a normatização constitucional. $\bigcirc$ verbo reflexivo "reunir-se" refere-se ao conceito de reunião que, corretamente, dá alcunha ao direito fundamental.

Trata-se do fenômeno das reuniões de pessoas naturais, que estará presente toda vez que pelo menos três pessoas (colégio mínimo), logicamente, porém, também duas pessoas se encontrarem em determinado local, compartilhando um propósito comum. ${ }^{59}$ Para alguns autores, a presença de apenas duas pessoas bastaria, porque, entre eles, por exemplo, Michael e Morlok (2016, p.

\footnotetext{
58 Sobre o conceito, cf. Dimoulis e Martins (2014, p. 133 e 135 s.).

59 Cf., entre muitos: Michael e Morlok (2016, p. 160 s.).
} 
159-160) partem do aspecto comunicativo e de desenvolvimento coletivo da personalidade ínsito à liberdade de reunião: ela protegeria, segundo esse entendimento, o indivíduo contra seu isolamento.

No mais, a reunião constitucionalmente protegida pelo dispositivo em pauta deve se realizar em um determinado local. Entenda-se como tal um local físico, não um local virtual. Encontros virtuais são protegidos por outros direitos fundamentais de comunicação social, isso porque é a partir do estudo da demanda específica de proteção que se define essa característica. Pelo direito fundamental à liberdade de reunião opõe-se um obstáculo àquela que é, em princípio, possível e potencialmente legítima competência estatal de impedir que pessoas se juntem, com emprego de seus corpos $^{60}$ em prol de algo que desejem comunicar, em um determinado local físico.

Prosseguindo no estudo do teor, tem-se de investigar o alcance do conceito do aludido propósito "comum". Primeiro, por definição negativa, exclui-se o chamado "propósito de todos", que também responde por sua conjugação plural como "propósitos paralelos". Algumas pessoas (ou até uma multidão) podem estar juntas em um determinado local sem comungarem um propósito comum. Pessoas que estejam em meros aglomerados, tendo todas elas o mesmo propósito de, por exemplo, esperar a passagem de um ônibus em uma parada para tanto construída ou de assistir a um evento musical ou quaisquer outras formas de entretenimento protegidas por outros direitos fundamentais não se encontram "reunidas" no sentido do art. 5 XVI CF.61 Muito se discutiu, no direito alemão, se, para a verificação de uma reunião no sentido da tutela jusfundamental em comento, haveria a necessidade de ser manifestada uma opinião como contribuição para o - ou participação no - processo de formação da opinião pública. Distinguiram-se, na sistematização das posições, três conceitos de reunião: de um conceito estrito segundo o qual haveria a necessidade de se manifestar, na reunião, uma opinião como participação no processo de formação da opinião pública (i.), passando pela exigência de ocorrência de uma manifestação de qualquer opinião, ainda que pertinente a interesses particulares - "conceito ampliado" (ii.), chegando a um conceito amplo, segundo o qual nenhuma opinião precisaria ser manifestada (iii.). ${ }^{62}$

A par dessa definição negativa, trata-se de passeatas, marchas ou aglomerações de pessoas naturais em determinado lugar (fixo ou transitório a depender do tipo de reunião) ${ }^{63}$ que tenham por

\footnotetext{
$\overline{60}$ Cf. Kniesel e Poscher (2007, p. 1009 ss.).

${ }^{61}$ No que se refere aos eventos de entretenimento que ocorram em praças, vias e demais logradouros públicos, o conceito de reunião será relevante inclusive para a determinação do ramo de direito administrativo aplicável: se o direito de reunião ou o direito de uso das vias públicas, com repercussões práticas para efeitos de concessão de autorização especial e obrigação de ressarcimento de custos da limpeza dos locais, por exemplo. Cf. da extensa literatura germânica nesse sentido: Mager (2014, p. 287 s.), com referência à abordagem crítica e bastante analítica de Tschentscher (2001, p. 1235 s.).

62 Cf., por muitos: Möllers (2015, p. 186 ss.) e Schildheuer (2015, p. 207 ss., 232).

63 Na literatura especializada germânica, cf., por todos, as "formas de reunião" descritas por Pieroth et al. (2016, p. 358 s. e 359-362). A par da recorrente dicotomia "locais abertos versus locais fechados", apresentam uma segunda dicotomia muito relevante para a aplicação da lá vigente Lei de Reuniões - BVersG (lex specialis) e das leis estaduais gerais de segurança pública (legi generali), qual seja: "reunião pública versus reunião não pública". Combinando as duas dicotomias, identificam-se quatro tipos de reunião: públicas em locais abertos, públicas em locais fechados, não públicas em locais abertos, não públicas em locais fechados. A caracterização como pública ou não dependerá das determinações prévias dos organizadores, as quais predeterminam ou não um público-alvo, especificamente convidado/convocado para a reunião. Tais predeterminações fazem também parte da área de proteção do direito fundamental; na dúvida, também o fazem em face do teor e contexto normativo do art. $5^{\circ}$, XVI CF.
} 
escopo chamar a atenção para qualquer questão política, social ou cultural. Presente deve estar uma interdependência entre os reunidos que comungam do mesmo propósito, em princípio com vistas à apresentação de uma opinião, ainda que com concepções individuais eventualmente divergentes. Em seu aspecto de contribuição para a formação da opinião pública, é justamente do livre debate entre posições convergentes ou divergentes que se trata. ${ }^{64}$

\subsubsection{Delineando a área de proteção: exclusão de reuniões não pacíficas e "armadas"}

Verificada a presença de uma reunião no explicado sentido constitucional que configura o cerne de sua área de regulamentação ou área da vida social sobre a qual a norma constitucional incide, dá-se o primeiro passo rumo à definição da área de proteção do direito fundamental. É o atingimento da área de proteção por um órgão estatal pertinente em termos funcionais a qualquer um dos três poderes que faz com que o mesmo órgão estatal, destinatário normativo da norma de direito fundamental em tela por excelência, seja obrigado a cumprir um determinado ônus argumentativo. Tal ônus é pautado na dogmática dos limites e limites dos limites aos direitos fundamentais. ${ }^{65} \mathrm{Nem}$ sempre se depreende do teor de uma norma definidora de direito fundamental uma clara opção do constituinte por excluir da área de proteção aqueles comportamentos ou situações não considerados por ele dignos de proteção ab initio, a despeito de serem pertinentes à área da vida social regulamentada. No presente caso, tem-se a literal exclusão de reuniões que adquiram caráter não pacífico ou cujos membros portem armas.

Em síntese, nessa primeira etapa do exame, o intérprete pode ter à sua frente um encontro de pessoas: primeiro, que não se encontrem reunidas no discutido sentido do art. $5^{\circ}$, XVI CF; ou, segundo, que, mesmo se encontrando reunidas, não atendam às duas referidas condições. Em ambos os casos, uma hipótese de violação restaria refutada já nessa fase preliminar da primeira etapa do exame.

Critérios para a aferição do caráter pacífico de uma reunião foram fartamente desenvolvidos no direito comparado alemão cuja norma definidora do direito fundamental, nessa etapa da fixação do seu suporte fático, é praticamente idêntica à norma do art. $5^{\circ}$, XVI CF. Porém, também lá muitos são os aspectos controvertidos. Até mesmo o aparentemente objetivo critério do porte de armas revela problemas hermenêuticos e práticos. ${ }^{66}$

O caráter pacífico de uma reunião não estará, em regra, presente, quando o elemento comunicativo da reunião desvirtuar-se em violência física contra pessoas e/ou coisas ou adquirir trans-

\footnotetext{
64 Um aspecto que em si faz parte do caráter jurídico-objetivo do direito fundamental, mas que, de modo teleológico, ajuda a precisar o alcance do conceito de reunião.

${ }_{65}$ Cf. Martins (2012a: p. 30-43) e Dimoulis e Martins (2014, p. 151 ss.).

66 Cf. Michael e Morlok (2016, p. 167). Os referidos autores destacam, todavia, que, embora objetos como tomates, ovos ou mesmo objetos de proteção como guarda-chuvas e capacetes não sejam em si armas no sentido constitucional, sua "utilização violenta" configura o caráter não pacífico de uma reunião, excluindo, igualmente, uma reunião com essa característica do suporte fático do art. 8, I GG. O mesmo raciocínio pode ser aplicado, sem percalços, na interpretação do art. $5^{\circ}$, XVI CF.
} 
curso sedicioso. A Lei Federal de Reuniões da República Federal da Alemanha (BVersG), em seu $₫ 13$ I, n. 2, definiu a condição negativa da ausência do caráter pacífico de uma reunião com essas duas características do transcurso violento ou sedicioso, acrescentando a iminência de sua ocorrência. ${ }^{67}$

No primeiro caso, do transcurso violento, trata-se de se excepcionar as únicas condutas, penalmente tipificadas, cuja norma definidora, sua interpretação e aplicação não precisam ser justificadas constitucionalmente por não atingirem a área de proteção da norma jusfundamental: a lesão corporal e o dano, além de suas tentativas. ${ }^{68}$ Questionável é se o mero planejamento de atos de violência ${ }^{69}$ implicaria tornar a reunião ab initio desprotegida pelo correspondente direito fundamental. Na dúvida, a reunião é protegida até o ponto de se verificar, concretamente, uma tentativa da prática de atos violentos, mesmo porque também uma reunião pacífica poderá sofrer intervenções estatais justificadas no momento da imposição dos limites constitucionais do direito fundamental. A consequência jurídico-dogmática é a submissão da intervenção, em princípio pautada em limite constitucional, ao ônus argumentativo estatal como restará demonstrado ao cabo do estudo de caso.

No segundo caso de a reunião adquirir um transcurso sedicioso, tem-se de avaliar que, por mais questionadora do establishment que seja uma reunião ou uma marcha, deve poder ser esperado dela um mínimo de comprometimento com a ordem constitucional vigente. ${ }^{70}$ Até porque é tal ordem que protege justamente a manifestação de opiniões minoritárias, exóticas e/ou mesmo potencialmente muito desagradáveis não apenas para os detentores de poder político, mas também para a maioria da população. ${ }^{71} \mathrm{O}$ referido comprometimento mínimo faltará quando uma reunião tiver por precípuo escopo atacar a ordem constitucional, tendo um ímpeto revolucionário que se corporifica, por exemplo, em ataques deliberados a forças de segurança policiais, que são competentes para assegurar a ordem e a segurança públicas. ${ }^{72}$ Lembre-se, aqui, do conceito de "democracia militante" ${ }^{73}$

\footnotetext{
67 Cf., na ampla discussão da literatura especializada: Möllers (2015, p. 188 s.). No mais, na Alemanha, a previsão de um transcurso violento, que seja capaz de atingir a segurança pública, pode fundamentar uma decisão judicial administrativa de proibição de sua realização com fundamento no \$ 15 I BVersG. Cf. a respeito Pieroth et al. (2016, p. 374-375).

68 Tais tipos penais são excepcionados porque não têm o condão de representar uma intervenção estatal na área de proteção pela simples razão de ter o constituinte excluído as condutas lá tipificadas da área de proteção do direito fundamental em tela. 69 Tendo em vista a certificação quanto ao respeito ao vínculo escalonado ao direito fundamental e em face do princípio da essencialidade conecto ao da legalidade, sem dúvida tal intervenção somente poderia se processar, em tese, com claro lastro legal, caso em que se poderia pensar até mesmo na previsão da proibição de uma reunião planejada via decisão jurisdicional administrativa, como ocorre no já mencionado §15 BVersG. V. a análise aprofundada de Enders et al. (2011, p. 39-43).

70 Não faria sentido considerar que o constituinte tenha aceitado a possibilidade de ter criado uma ordem constitucional vulnerável em relação a movimentos revolucionários. Toda ordem constitucional, também uma de perfil democrático e que tutele direitos fundamentais de minorias políticas, tem a pretensão de ser perene.

71 É essa assimilação de correntes ideológicas não seguidas pela maioria que, predominantemente, caracteriza uma ordem constitucional como democrática e liberal, na acepção da prevalência lógica dos direitos fundamentais de liberdade individual que se realiza pela aplicação do chamado princípio distributivo (do ônus argumentativo). Cf. Schlink (1984) e, novamente, Martins (2012a, p. 28-43).

72 Cf. Möllers (2015, p. 189).

73 Conceito cunhado por K. Loewenstein e K. Mannheim já na década de 1930. Cf. Loewenstein (1937, p. 417-433 e 638-658). Significa, em suma, que cada titular de direito fundamental submete-se, inobstante sua ampla liberdade de manifestação do pensamento e de consciência e crença, ao dever fundamental de lealdade constitucional (Verfassungstreue), ao qual corresponderia, em um exercício de personificação da democracia, ao seu "direito à autodefesa" (conceito também alcunhado de "wehrhafte Demokratie", em alusão direta ao conceito de defesa). No contexto do direito fundamental especial de igualdade de direitos e obrigações dos cidadãos alemães em face do serviço público, na forma do que foi garantido pelo art. 33 I GG (igualdade de acesso aos quadros do funcionalismo público sem discriminações, sobretudo religiosas), Pieroth et al. (2015, p. 132 s.)
} 
segundo o qual a ordem constitucional democrática deve ser apta a responder, sem quebra institucional e violação de direitos de minorias ideológicas, de maneira idônea, aos ataques provenientes de radicais à direita ou à esquerda do espectro político-ideológico.

Questionável é se a mera violência psíquica, ${ }^{74}$ tal como a presente em ações de bloqueio de vias, autoestradas ou ferrovias por manifestantes sentados ou deitados, descaracterizaria o seu caráter pacífico. ${ }^{75}$ Sem dúvida, trata-se de uma reunião no sentido constitucional. Estão presentes o elemento comunicativo e o de comunhão de propósitos. A tendência, no direito comparado alemão, é afirmar, pelo menos em princípio, o caráter pacífico. ${ }^{76}$ Resolve-se o choque entre esse tipo de reunião e outros bens jurídicos apenas na etapa da justificação constitucional, não nessa primeira etapa em que se procede à subsunção da pretensão de exercício de direito fundamental à hipótese normativa em si, ao suporte fático da norma definidora de direito fundamental. Na etapa da justificação constitucional, que representa a terceira principal e estrutural etapa do exame de uma hipótese de inconstitucionalidade com fulcro na violação de direito fundamental, avalia-se, especificamente, a constitucionalidade em tese do tipo penal. Mas não apenas. Nessa etapa, avalia-se, sobretudo, a interpretação e aplicação da consequência jurídica (sanção) prevista na norma definidora do crime de constrangimento ilegal. ${ }^{77}$ Como no caso a ser examinado no tópico III, trata-se de perscrutar os

advertem, todavia, para o risco da discriminação de posições ideológicas marginais ao establishment estatal quando se evocam com exagerada ênfase os conceitos de lealdade constitucional e da democracia militante. $O$ referido risco foi, todavia, muito bem prevenido pelo constituinte alemão ao estabelecer o monopólio decisório do TCF (visto pela perspectiva da garantia, trata-se de uma espécie de "prerrogativa de foro"), entre outro (art. 18 GG), para o processo de proibição de partido político (art. 21 II 2 GG) a partir da verificação de seu caráter de inimigo da ordem constitucional feita pelos legitimados para a ação. Cf. também com mais referências: Jarass (2011, p. 454) e Pieroth (2011, p. 559).

74 Violência psíquica (vis compulsiva) pode ser definida como uma tomada de influência ou poder sobre uma pessoa por intermédio de coerção psicológica. Ela pode ocorrer de maneira sutil mediante subterfúgios psicológicos e, não raramente, está presente em contextos de assimetria social entre o ator da violência e sua vítima em situação de vulnerabilidade. Daí ser, comumente, lembrada no contexto da violência doméstica ou em situações de grave vulnerabilidade socioeconômica. $\bigcirc$ problema do conceito aplicado ao sistema jurídico permanece, todavia sua insuficiente determinabilidade ou certeza, que tem o condão de ferir o princípio constitucional objetivo do mandamento de determinabilidade/taxatividade, decorrente do princípio do Estado de direito (art. $1^{\circ}$, caput CF).

75 Cf., por exemplo, da jurisprudência germânica, as decisões alcunhadas de Sitzblockaden (na tradução literal: "bloqueios sentados"): BVerfGE 73, 206; 92, 1 e 104, 92 (respectivamente: Sitzblockade I, II e III) e a literatura de resenha crítica: Möllers (2015, p. 57, 188 s. e 329). Tanto as decisões citadas do TCF quanto a literatura crítica que a acompanham trazem à pauta, além do direito fundamental do art. 8 I GG, a garantia constitucional processual prevista no art. 103 II GG da nulla pena sine lege. Tratava-se, em ambos os casos decididos, de se controlar a interpretação e aplicação do $₫ 240$ do Código Penal alemão que define o crime de coerção (equivalente ao constrangimento ilegal do CPB) em face de uma derivação de conteúdo que é a proibição da analogia na aplicação de norma penal: nulla pena sine lege "certa" (cf. Möllers, 2015, p. 328).

76 Cf., por exemplo, por todos, com suaves reservas na formulação: Hufen (2016, p. 485 ss.): "Também puros bloqueios por pessoas sentadas não são ab initio não pacíficos [...] Isso vale também - enquanto não forem investidos outros meios não pacíficos - para reuniões que, por excelência, queiram atrapalhar certos processos econômicos ('Blockupy')."

77 Nas Decisões Sitzblockaden, tratava-se, precipuamente, do exame da possível violação do art. 103 II GG, que garante ao titular desse que é um "direito igual a direito fundamental" (por não estar no devido capítulo da Grundgesetz), a aplicação do princípio nulla pena sine legem, o qual, por sua vez, abrange a tradicional proibição de analogia em matéria penal. O problema era fazer o conceito de violência abarcar a violência psíquica implícita na barreira corporal dos manifestantes sentados a transporte de lixo atômico. O TCF discorreu que deve haver o "desenvolvimento de uma força" pelo agente sobre o constrangido. Sobre quão intensa deva ser essa força variaria de caso para caso, cf. Sinn (2011, p. 286). Analisa-se aqui a relação meio-fim implícita no propósito da reunião, Cf. Schluckebier (2014, p. 1469 s.). Por isso que o ato de manifestantes se acorrentarem, ou a intenção de prolongar a reunião de bloqueio por tempo indeterminado, pode ser sancionado por deixar de ser necessária para os efeitos comunicativos reivindicatórios pretendidos: cf. Sinn (2011). O mesmo autor (SINN, 2011, p. 1467), em seus comentários ao $₫ 240$ StGB, ressalta, ao revisitar as decisões em pauta do TCF, que "em tais casos (estabelecimento de uma barreira física) com caráter demonstrativo a questão da antijuridicidade carece sempre de exame especial." Demonstration, Demonstrationsfreiheit são conceitos similares ao direito fundamental em pauta, correspondendo a "manifestação" e sua liberdade, por 
critérios para se avaliar a constitucionalidade de intervenções estatais no direito fundamental em apreço perpetradas pelo legislador penal e pelos órgãos jurisdicionais penais ao interpretarem e aplicarem a lei penal.

Dessa hipótese de proteção devem ser apartados os bloqueios incendiários. ${ }^{78}$ Por causa de seu alto potencial lesivo à integridade física de pessoas e de provocação de danos, excluem-se da área de proteção do direito fundamental tais condutas, pouco importando seu uso como instrumento de protesto político. Estas também devem ser consideradas sediciosas no sentido apresentado. Destarte, mesmo sendo reunião no sentido constitucional, não cumprem a condição apriorística do caráter pacífico que deve ser observado, já nesse ponto, pelos titulares do direito.

A conduta não pacífica de apenas alguns manifestantes não descaracteriza o caráter pacífico de toda uma reunião, desde que não haja uma "contaminação" de parte considerável de seus integrantes. ${ }^{79}$ Pelo contrário, gera a necessidade do cumprimento de dever estatal de tutela por parte de forças policiais. ${ }^{80}$

Por fim, "armas" no sentido do dispositivo constitucional podem ser quaisquer objetos aptos a causarem lesões corporais. Deve estar presente a intenção de, efetivamente, usá-los. Isso não se verifica, salvo elementos fáticos que apontem em sentido contrário, em manifestações de militares ou de trabalhadores rurais cujos integrantes tragam consigo, como marca simbólica, instrumentos de trabalho que sejam em si considerados perigosos. ${ }^{81}$

\subsubsection{Alcance do direito fundamental e concorrências}

Uma vez excluídos os comportamentos e as situações ab initio não contemplados pelo constituinte, protegidas são reuniões havidas "em locais abertos ao público". O constituinte não ressalvou as reuniões feitas em locais fechados ao público da livre disposição do legislador ordinário e demais autoridades públicas em razão da incidência de outros direitos fundamentais que concorram

vezes muito utilizada na literatura jurídica e principalmente jornalística. Essas nuances verificadas em cada manifestação de obstrução deverão ser consideradas na intersecção das dogmáticas penal, com a exclusão ou não da antijuridicidade; e constitucional, primeiro com a verificação ou não da contemplação da conduta pela área de proteção do direito fundamental e segundo, uma vez presente a primeira condição, pela justificação constitucional ou não da intervenção estatal.

78 Bloqueios incendiários preenchem os elementos objetivos do tipo penal de incêndio (art. 250 do CPB). Como a atuação repressora e o sancionamento penal de tais condutas não podem preencher o suporte fático da norma jusfundamental em apreço, seus autores não podem se valer, por exemplo, da figura do exercício regular de direito (art. 23, III, $2^{\mathrm{a}}$ alt. CPB), ou seja, de uma causa excludente da antijuridicidade, como poderia ocorrer, em tese, com o bloqueio de pessoas sentadas. Nesse caso, tem-se uma coerção psíquica passiva que, por sua vez, não estará presente se os manifestantes se prenderem a correntes, por exemplo.

79 Trata-se de opinião amplamente majoritária na discussão germânica. Cf. por todos: Pieroth et al. (2015, p. 200), com a muito importante ressalva: "Entretanto, a reunião tornar-se-á não pacífica quando o corpo diretor da reunião ou a maioria dos participantes solidarizarem-se com o comportamento não pacífico de alguns."

80 Cf. com análises exaustivamente diferenciadas: Pieroth et al. (2016, p. 355-389).

81 A aludida intenção de uso de um objeto com potencial de arma ou desta em sentido estrito relaciona-se à interdependência com a outra condição para o exercício protegido da liberdade, que é o caráter pacífico da reunião. A finalidade implícita no uso do instrumento deve ser facilitar a prática de condutas típico-penais. Cf. Thiel (2016, p. 259), com referência expressa a Gusy (2014). Ressalvada a possibilidade de prova contrária, em princípio é evidente que a referida finalidade não está presente nas mencionadas reuniões. 
com a liberdade de reunião, tal qual da inviolabilidade do domicílio. Poder-se-ia pensar também na liberdade profissional ou na liberdade de crença. ${ }^{82}$

Teleologicamente argumentando, a razão da diferenciação constitucional entre reuniões em locais abertos ao público e reuniões em locais não abertos é, como também o restante do dispositivo revela por seu teor, o potencial de reuniões em locais abertos ao público chocarem-se contra outros bens jurídicos. Pense-se, precipuamente, na gestão pelo Poder Público do uso ordinário e extraordinário de locais públicos como vias urbanas, praças e autoestradas e seu dever de combater perigos abstratos e, precipuamente, os perigos concretos derivados do exercício do direito fundamental. ${ }^{83}$

Esse problema não se apresenta em reuniões realizadas em locais fechados. Estas são indiretamente protegidas, na medida em que se protege como direito fundamental, entre outras, a intimidade espacial do ambiente em que se realizem, caso em que se traz à baila, como aludido, o direito fundamental à inviolabilidade do domicílio. Isso quer dizer que, a depender de seus diferentes escopos e dos ambientes fechados ao público em que esteja sendo realizada, uma reunião será protegida pelo direito fundamental à inviolabilidade do domicílio ou à liberdade profissional, à liberdade de imprensa, à liberdade de crença ou outras imagináveis que constem no catálogo de direitos fundamentais de liberdade.

Não obstante, em todos os aludidos casos, têm-se ambientes não apenas fechados ao público, mas também privados. ${ }^{84} \mathrm{Se}$, de um lado, para ambientes abertos ao público, o constituinte considerou a priori digna de proteção específica toda reunião pacífica, deixando a proteção das reuniões em ambientes fechados a cargo de outros direitos fundamentais individuais; de outro, não preten-

\footnotetext{
82 Trata-se de uma concorrência "ideal" e não apenas "aparente". Sobre o conceito de concorrência e suas duas referidas variantes: Dimoulis e Martins (2014, p. 171-175). A consequência da presença de uma concorrência ideal para o exame de constitucionalidade é que (todos) os objetos do controle devem ser medidos com base em cada direito fundamental concorrente; não se podendo excluir parâmetros supostamente genéricos em prol de específicos (caso da concorrência meramente aparente). Praticamente todos os autores germânicos reconhecem em suas análises a concorrência em tese da liberdade de reunião com os direitos fundamentais mencionados no texto. Por todos, cf. Hufen (2016, p. 487 s.). No conhecido caso decidido pelo STF, na ADPF 187 (Marcha da Maconha), teria sido o caso de se realizar o exame em face tanto da liberdade de reunião, quando o objeto eram as arbitrárias e absurdas proibições judiciais da realização dessa forma de reunião com pauta em preconceitos dos julgadores (hipótese de prevaricação judicial deveria ser também testada), quanto de manifestação do pensamento diante de condenações por crime de apologia também absolutamente infundadas. Em ambos os casos, tem-se erros crassos de simples interpretação e aplicação das normas penais e não propriamente intervenções estatais violadoras dos aludidos concorrentes direitos fundamentais. Mesmo a hipótese de concorrência poderia ser colocada em dúvida, pois se trata de duas medidas interventivas abstratamente avaliadas pelo STF e que, quando atuais, atingiriam cada qual um direito fundamental diferente. Em rigor, a ADPF não poderia ser conhecida sem prejuízo da admissibilidade e do mérito procedente dos RE que chegassem ao STF e de cabíveis medidas disciplinares e penais contra os juízes que não têm como alegar a própria inépcia (iura novit curia!). Sobre a decisão, vide a crítica e sua reconstrução ainda imprecisa em Martins (2013).

83 Perigos abstratos podem ser, em geral, prevenidos por intermédio de repartições públicas especializadas, tecnica e legalmente competentes. Os planos de combate a tais perigos não atuais são concebidos, por assim dizer, "da mesa de trabalho" (ou do gabinete) dos servidores públicos responsáveis. Em regra, devem ser respaldados em normativas ou leis em sentido material (decretos, resoluções, portarias, etc.) de autoria do competente órgão ou, ainda, suscitar medidas de prevenção a perigos pertinentes às suas respectivas atribuições e margens de ação discricionária (prática administrativa consolidada). Já os perigos concretos são enfrentados por medidas de combate atual, em sua maioria por forças policiais, órgãos de persecução penal e de combate a calamidades (bombeiros, defesa civil, etc.). Cf. Pieroth et al. (2016, p. 63-69).

84 Independentemente do fato de poder ser uma reunião "pública" ou "privada", apesar de a titularidade do domínio da edificação em que se realize ser privada ou ser estatal. Cf. novamente a referência à nota 63.
} 
deu, em absoluto, proteger reuniões convocadas para aqueles prédios públicos não reservados a essa finalidade. ${ }^{85}$ Trata-se de uma reunião que tenha a possibilidade de se expandir, em tese, para todas as direções, de acesso livre, portanto. ${ }^{86}$ Sabidamente, repartições públicas são abertas ao público dentro de um determinado horário de funcionamento e para uma determinada finalidade. É principalmente sua capacidade funciona ${ }^{87}$ que está em jogo. Portanto, a ocupação de prédios públicos para fins de protesto, pouco importando a causa defendida, considerando o mandamento de neutralidade ética do Estado, 88 não é abrangida pela área de proteção da liberdade de reunião. É o que ocorre, sobretudo, porque não configuram locais "abertos ao público" no sentido do artigo $5^{\circ}$, XVI CF.

Investigando-se um pouco mais a fundo o sentido da cobertura de proteção exclusiva a locais abertos ao público, uma vez sobrepujados os já discutidos elementos de proteção negativa (ou de exclusão) do caráter pacífico e não porte de armas, chega-se à análise do intrincado relacionamento entre os demais elementos constitutivos do dispositivo constitucional em comento. Por intermédio de tal esforço analítico em sentido estrito, pode-se derivar da intrínseca relação sistemática da locução "independentemente de autorização", que sucede a locução "em locais abertos ao público", com esta, a contrário senso, a necessidade de se colher uma autorização para a realização de reuniões realizadas em locais fechados ao público. Com a derivação dessa necessidade, deriva-se também a possibilidade de ser autorizada a realização de uma reunião em locais fechados ao público. Como direitos fundamentais são normas que disciplinam, em primeira e essencial linha, a relação de seus titulares para com o Estado, tendo eficácia perante particulares apenas indireta ou mediatamente - pelo medium do vínculo do Estado-juiz ao direito fundamental, ${ }^{89}$ tratar-se-ia da possibilidade de órgãos administrativos autorizarem a realização de reuniões nas dependências de repartições públicas. Já em âmbito de direito administrativo, tais autorizações teriam de ser medidas

\footnotetext{
85 Lembre-se que se trata de um direito de resistência à intervenção estatal, que pressupõe metodologicamente uma estrita separação entre Estado e sociedade e que, para além daquela conhecida teoria da separação, tem repercussões práticas muito concretas. Não se trata de um direito de status activus que preconizaria, pelo menos em tese, uma pretensão ao uso de repartições públicas. Cf. Dimoulis e Martins (2014, p. 50 ss. e 53 ss.) e o aprofundamento teórico e metodológico em Martins (2012a, p. 7-43).

${ }_{86}$ Embora se parta, para a conceituação das formas de reunião, de uma dimensão antes social do que espacial. Nesse sentido, cf. Pieroth et al. (2016, p. 359): "reuniões ao ar livre [lit.: "sob o céu livre" - art. 8 I GG] são aquelas que são realizadas no [contexto do] tráfego público, independentemente das [suas] relações com edificações." Nada obstante, nesse sentido, traz-se à pauta, por exemplo, um shopping center devidamente coberto e com segurança privada em suas entradas, mas nunca uma repartição pública.

87 Capacidade funcional é a garantia dos meios necessários ao cumprimento das tarefas confiadas legal e constitucionalmente a determinado órgão; no caso, a garantia de uma repartição pública livre de estorvos provenientes de manifestantes. Em última instância, serve ao bem-estar coletivo. Por isso, recebe as mais diversas conotações como meios de se chegar a propósitos pertinentes àquele, podendo se contrapor a determinados interesses particulares respaldados até por direito fundamental. Assim ocorre, por exemplo, na potencial situação de conflito entre os interesses no acesso à informação arquivada em órgãos públicos e na manutenção provisória de sigilos, por vezes imprescindível à capacidade funcional. Nesse sentido, cf. Kugelmann (2001, p. 77 ss., 162, 326 ss. e passim); e especificamente no campo do direito policial: Schenke (2016, p. 34): proibição de identificar e fotografar policial, uma vez presentes determinadas circunstâncias. Em relação ao âmbito da "boa administração da Justiça": MARTINS (2012a, p. 349; n. rod. 131).

88 V. a respeito, em geral, a muito analítica exposição monográfica de Huster (2002). Enfatiza-o também Koll (2015, p. 295-235) que, como aqui, parte de um entendimento liberal do direito objetivo de reunião, apesar das competências para o Estado intervir legislativamente e da possibilidade de uso do instrumento da cooperação entre manifestantes e Estado, o que, segundo ele, implica "chance e perigo" ao mesmo tempo (cf. Koll, 2015, p. 305-324).

89 Cf. Martins (2012a, p. 89, 100-116).
} 
com base na "prevalência do interesse público", apesar da forte indeterminação desse conceito. Em âmbito de direito constitucional, esbarrariam no aludido princípio objetivo da neutralidade ética e, jurídico-subjetivamente, no direito fundamental à igualdade dos titulares não contemplados com a prerrogativa. Com lastro interpretativo no horizonte do constituinte histórico, não se pode excluir a possibilidade de o sentido pensado pelos constituintes ter sido justa e equivocadamente (crítica de constitutione ferenda) a obviedade de um particular, titular do domínio sobre determinada edificação ter de aquiescer com a realização de dada reunião no local "fechado ao público". Mas esse sentido não tem como prosperar por razões bastante óbvias ligadas às mais elementares faculdades do proprietário e/ou possuidor (exceto se restringidas por lei compatível com os direitos fundamentais do proprietário e/ou possuidor), mesmo que de um estabelecimento comercial, cujas portas são abertas ao público com a finalidade jusprivatista específica e cujas atividades recaem, de resto, na área de proteção de outros direitos fundamentais, como do art. $5^{\circ}$, XIII CF.90

No mais, o alcance da área de proteção da liberdade de reunião estende-se, ainda, de maneira bem específica, à escolha do local de sua realização, do trajeto no caso de passeatas ou marchas e do horário, assim como a todas as medidas pertinentes à sua organização e divulgação prévias. ${ }^{91}$

Por fim, quem se manifesta pode se valer do anonimato, ao contrário do que difusamente se defende mediante referência à vedação do anonimato prevista no art. $5^{\circ}$, IV CF. Esse entendimento é equivocado porque ignora o sistema normativo jusfundamental: é vedado ao intérprete transplantar exclusões de tutelas pertinentes à área da vida regulamentada pelo constituinte ou limites previstos por ele a um específico direito fundamental a outro direito fundamental. Caso contrário, subverte-se o sistema de liberdades e seus limites tal qual configurado pelo constituinte. ${ }^{92}$ Qualquer

\footnotetext{
90 O "Hausrecht" ("Direito da Casa", na verdade: do senhorio ou dono do imóvel ou estabelecimento comercial) tem respaldo no direito civil de propriedade (\$\$ 858 ss., 903, 1004 BGB), mas também na inviolabilidade do domicílio no âmbito civil. Tem a ver, historicamente, com a paz domiciliar que pode ser ilicitamente quebrada ("Hausfriedensbruch") e fundamentar uma proibição de entrada (Hausverbot), segundo o mote: "minha casa, minhas regras". É o que ocorre mesmo e principalmente nos ambientes comerciais abertos ao público em geral, como shopping centers. Como o direito fundamental à liberdade de reunião, assim como os demais [v. com fundamentos teóricos divergentes daqueles aqui defendidos, mas com bom desenvolvimento argumentativo e consistência teórica: Silva (2005)], não tem eficácia direta perante particulares - à exceção de comprovada discriminação por causa de características definidas no art. $3^{\circ}$, IV CF e congêneres, como por causa da orientação sexual, e mesmo assim por conta do cumprimento pelo legislador ordinário de seus deveres estatais de proteção e mandados constitucionais legislativos - condôminos de um shopping center não são obrigados a tolerar a presença de pessoas que não sigam as regras comportamentais de seu regulamento interno, especialmente em prol do resultado econômico licitamente perseguido. Isso pode ocorrer sem prejuízo, é claro, do sancionamento penal dos eventuais abusos desse direito por ameaça ou lesão à integridade física ou moral dos "indesejados", por exemplo, como infelizmente muito frequentemente ocorre neste País de ranço social autoritário e não adepto do diálogo civilizado, quanto menos do debate racional de ideias. De resto, a função social da propriedade, limite do direito fundamental à propriedade por excelência, assim Martins (2012a, p. 180, 197-200), e como muitos defendem seu elemento constitutivo [vide também com uma abordagem em língua alemã comparativa dos art. 5, XXIII CF e art. 14 I 2 GG: Martins (2016b)], "não contém um dever do proprietário de tolerar ou permitir a realização de uma reunião (em sua propriedade)" (TÖLLE, 2017, p. 710). O TCF alemão até considerou um local ao "ar livre" (aberto ao público), no sentido do art. $5^{\circ}$, XVI CF e do art. 8 I GG, uma reunião feita dentro das dependências do Aeroporto de Frankfurt (BVerfG 128, 226), mas isso apenas porque o Estado é coproprietário daquele aeroporto, não se desviando, destarte, de sua consolidada jurisprudência da não admissão da eficácia horizontal direta. Cf. os bem analíticos comentários à decisão e efeitos pertinentes ao art. 1 III GG de Dreier (2013, p. 319-321). Crítico até mesmo em relação ao atingimento de tais propriedades mistas: Schenke (2016, p. 237).

91 Cf. por todos: Pieroth et al. (2015, p. 201 s.).

92 Extraem-se da vedação do anonimato consequências as mais absurdas que não têm como ser mais bem discutidas aqui por extrapolarem os limites da presente exposição. No caso em tela, o apontado equívoco da transposição indevida repousa
} 
medida de identificação promovida por forças policiais significa uma intervenção estatal no direito. Sendo intervenção, tem de ser justificada com fulcro em um limite constitucional para a liberdade de reunião. Deduzir o contrário seria atribuir ao Estado um poder específico ilimitado em face de um direito fundamental dos mais vulneráveis - porque potencialmente hostis a governantes de plantão - qual seja: um poder de intimidar ou desestimular o exercício do direito fundamental, causando um efeito de autocensura psicológica aos seus titulares. ${ }^{93}$

Exemplos aqui dos mais recentes e eloquentes para ilustrar esse reconhecimento são os manifestantes alcunhados de "black-blocks". Caracterizados por ocultarem seus rostos em manifestações, têm tal escolha protegida pela liberdade de reunião, desde que cumpram os pré-requisitos do caráter pacífico e não porte de armas, que não procedam à violência física e que não causem dano ao patrimônio público ou privado. ${ }^{94}$

\subsubsection{Para além do suporte fático: limites constitucionais à liberdade de reunião potencialmente justificadores de intervenções estatais}

Verificando-se a pertinência de uma conduta à área de proteção, perdura a hipótese de violação, ainda não comprovada definitivamente. Isso porque uma reunião que seja, em princípio, protegida, pode sofrer intervenções estatais provenientes de órgãos dos três poderes, possivelmente

\footnotetext{
sobre os seguintes aspectos. Em primeiro lugar, em geral, a transposição de um limite ou mesmo - como no caso - de uma aparente condição prévia ao exercício de um direito fundamental é absolutamente vedada, sob pena de se subverter, como aludido no texto, o sistema de proteção jusfundamental concebido pelo constituinte. As condições para o exercício e limites externos para cada direito fundamental são taxativos. Em segundo lugar, condições prévias ao exercício a serem cumpridas pelo titular do direito ou limites externos à disposição dos órgãos e poderes constituídos estatais (mediante reservas legais ou direito constitucional colidente) representam respostas do constituinte a potenciais situações de conflito e ao perigo que uma outorga ilimitada de liberdade poderia implicar. Responde-se, portanto, a perigos específicos provenientes do que se poderia considerar abuso da liberdade de reunião, visto que é ônus das autoridades estatais demonstrarem quais perigos específicos seriam estes e como se reagir a eles proporcionalmente. Por fim, é vedado ao Estado criar quaisquer tipos de embaraços ou constrangimentos preliminares ao exercício das liberdades, especialmente de uma liberdade de grande potencial contestatório como a liberdade em apreço. Também por essa característica, lembre-se, ela é instrumental em face do processo democrático como um todo (potencial contribuição para a formação da opinião pública). Destarte, o constituinte sabiamente não excluiu da proteção da liberdade de reunião a tutela daqueles partícipes que, por receios os mais variados, pretendam ocultar suas identidades. Imagine-se, entre uma infinidade de possíveis outros exemplos, que um manifestante não queira que em seu ambiente de trabalho mais conservador se saiba que ele se engaja pela legalização das drogas ou pelo casamento entre pessoas do mesmo sexo. $O$ interesse por trás de tais receios, desde que presentes determinados pressupostos, pode corresponder à tutela de direitos fundamentais de personalidade, como os direitos fundamentais decorrentes do art. $5^{\circ}$, X CF. A respeito, com aprofundamentos jurídico-dogmáticos: Martins (2016c). Por isso, também, que no direito de reunião alemão a medida policial da verificação de identidades expressamente prevista por leis gerais estaduais de segurança pública é vedada pela lex specialis da reunião. Recentemente, o TCF alemão julgou inconstitucional a verificação policial da identidade de partícipes de uma reunião que filmavam a atuação da polícia (cf. BVerfG NJW 2016, p. 1230 ss.), assim como também filmagens panorâmicas pela polícia que permitam a identificação de manifestantes.

93 A prevenção desse risco de autocensura, mandamento derivado, em parte, da dimensão objetiva dos direitos fundamentais à manifestação do pensamento e de comunicação social em geral foi enfatizada por vários autores, com destaque para Grimm (1995) em seu ensaio explicativo da decisão Soldados são assassinos.

$94 \mathrm{Na}$ Lei Federal de Reuniões alemã, em seu \} 1 7 \text { II VersG são proibidos manifestantes que se apresentem em passeatas de } uma forma "idônea a impedir a constatação da identidade e que segundo as circunstâncias tenha por finalidade o impedimento da constatação da identidade." ("Vermummungsverbot"). Trata-se, indubitavelmente, de uma intervenção muito onerosa na liberdade em apreço pelas razões já declinadas no texto e recorrentemente tematizada na literatura especializada, havendo quem a defenda e quem a rejeite. Contudo, tais opiniões também atuam junto à aplicação dos limites, não restando dúvidas de que se trate, como aqui afirmado, de uma escolha que faz parte prima facie da área de proteção. No mais, v. as bem-vindas especulações teóricas e políticas de Sarlet e Weingartner Neto (2014).
} 
justificadas constitucionalmente. Verificar uma intervenção estatal pressupõe a identificação precisa de todas as condutas e situações contempladas pelo direito fundamental, tecnicamente abrangidas pela área de proteção, o que foi feito até aqui. É a verificação de uma intervenção pela via da obstrução dos comportamentos ou de cargas sobre as situações ou seus sancionamentos a posteriori, o que torna dogmaticamente imprescindível o questionamento dos limites e limites desses, ensejando a busca do cumprimento pelo Estado de seu específico ônus argumentativo.

Assim, a par das locuções já analisadas relativas ao modo de reunião contemplado pela norma jusfundamental em pauta ("pacificamente, sem armas") ou ao ambiente/tipo da reunião ("em locais abertos ao público"), as demais locuções do dispositivo devem ser, do ponto de vista jurídico-dogmático, entendidas como limites constitucionais ao direito fundamental. Não fazem parte do suporte fático do direito fundamental em si, embora se encontrem no mesmo dispositivo constitucional. Aqui, convém deixar o texto para se adentrar no contexto normativo. Tais locuções implicam a possibilidade de o Estado, a começar pelo legislador formal, traçar, concretamente, limites em prol da defesa de outros bens jurídico-constitucionais e outras situações de risco ou periclitação de bens jurídicos mais vulneráveis.

Destarte, entre as locuções, a determinação do "prévio aviso a autoridade competente" somente pode ser entendida como meio para o alcance de dois tipos de propósito constitucionalmente lícitos: ou do propósito de impedir, objetivamente, que uma reunião frustre outra anteriormente convocada para o mesmo local, ou de todos os propósitos finais constitucionais naquele implícitos ou afins. Portanto, trata-se de um limite constitucional cujo traçado concreto deve ser justificado, cumprindo-se o aludido ônus argumentativo, e não de uma condição prévia para o seu exercício a ser atendida pelo titular como ocorre com as condições do "caráter pacífico" e "não porte de armas".

\section{Estudo de caso e parecer sobre sua situação jurídico-constitucional}

A dogmática jurídica do direito fundamental à liberdade de reunião, anteriormente sucintamente apresentada após a descrição de seus fundamentos teóricos e, em parte, metodológicos, deve ser mais bem explicitada por intermédio de sua aplicação a um caso concreto inspirado em uma decisão do Tribunal Constitucional Federal alemão. A escolha do direito comparado e, especificamente, desse caso, é pertinente à tarefa a que se propôs no presente artigo, porque tanto o texto quanto o contexto normativos da CF e da Grundgesetz alemã são - pelo menos no que tange ao suporte fático das respectivas outorgas da liberdade de reunião - bastante similares. ${ }^{95}$

95 Segundo o Art. 8 I GG: "Todos os alemães têm o direito de se reunirem, sem aviso ou autorização, pacificamente e sem armas." 


\subsection{Da tarefa do parecer jurídico-constitucional: Caso 0 anarquista ${ }^{96}$}

O cidadão brasileiro $\mathbf{B}$ luta por uma sociedade sem governo. Durante um evento de campanha eleitoral do Partido Z, ele apareceu em uma praça pública da cidade $\mathbf{C}$ na companhia de mais 10 conhecidos, "armado" com um alto-falante. Lá, tentou encobrir com o seu próprio os discursos dos membros do Partido Z. Ao mesmo tempo, seus 10 acompanhantes erguiam cartazes e distribuíam aos transeuntes panfletos com dizeres e palavras de ordem contra o plano de governo do Partido $\mathbf{Z}$, com destaque para sua política de segurança pública. "Segurança mata a liberdade", lia-se em um dos cartazes.

Incomodados com as ações hostis de $\mathbf{B}$ e seus parceiros, os membros do Partido $\mathbf{Z}$ chamaram a polícia que, ao chegar, exigiu, antes de tudo, que $\mathbf{B}$ entregasse seu alto-falante, pois estaria atrapalhando o transcurso do evento do Partido Z. Depois de $\mathbf{B}$ ter se recusado a fazê-lo, o comandante da ação policial, $\mathbf{P}$, admoestou $\mathbf{B}$ no sentido de que teria de prendê-lo caso ele continuasse a se insurgir contra a ordem de entrega do alto-falante. Depois de tal admoestação não ter sido atendida por B, um dos policiais sob o comando de $\mathbf{P}, \mathbf{P} \mathbf{1}$, segurou $\mathbf{B}$ firmemente, a fim de colocá-lo na viatura policial. B resistiu à investida de $\mathbf{P} \mathbf{1}$ com bastante energia, dando pontapés que, todavia, não tiveram o condão de atingi-lo. Notoriamente revoltado com toda a ação policial e considerando-a injusta, B desferiu em face de $\mathbf{P}$ e seus colegas de ofício, a caminho da viatura que distava a uns 300 metros, alguns gritos com teores como "porcos imundos" e "escravos do sistema". Sucederam-se cenas de tumulto porque dois dos colegas de $\mathbf{B}$ intervieram na tentativa de impedir sua condução coercitiva para dentro da viatura policial. Somente com a ação coletiva de outros oito policiais, B acabou sendo imobilizado e levado à próxima delegacia de polícia.

Passadas algumas semanas, B acabou sendo denunciado e, meses após a denúncia, condenado por resistência e por desacato, respectivamente, segundo os art. 329 e 331 do CPB, a uma pena de detenção e multa (sentença penal condenatória: SC).

Por intermédio de seu advogado, B sustenta que a sentença condenatória viola seu direito fundamental à liberdade de reunião decorrente do art. $5^{\circ}$, XVI CF porque, segundo seu entendimento, o juiz penal julgou uma notoriamente ilícita ação policial contra uma reunião como se lícita fosse. Ainda segundo sua alegação, a ação não seria punível, porque não seria sequer típica, uma vez que a ação policial não foi legal em sentido amplo.

Procede a alegação de $\mathbf{B}$ ?

\footnotetext{
96 O caso é uma adaptação ao direito constitucional e infraconstitucional pátrio de uma decisão da $1^{\text {a }}$ Câmara do $1^{\circ}$ Senado (Turma) do Tribunal Constitucional Federal alemão, de 2007, publicada no periódico jurídico-administrativo Neue Zeitschrift für Verwaltungsrecht - NVwZ. Ano 2007, p. 1180 ss. Cf. também seu uso em cursos de direitos fundamentais como, principalmente, de Schildheuer (2015, p. 231-235). Cf. também Rechtsprechungsauswertung - RA, 2007, p. 679686.
} 


\subsection{Parecer stricto sensu}

A alegação de $\mathbf{B}$ seria procedente se por intermédio da SC seu direito fundamental à liberdade de reunião decorrente do art. $5^{\circ}$, XVI CF tivesse sido violado. Para tanto, teria de estar presente uma intervenção estatal não justificada na área de proteção da liberdade de reunião.97

\subsubsection{Da área de proteção do direito fundamental à liberdade de reunião (art. 5º XVI CF)}

$\mathrm{O}$ art. 5', XVI CF garante aos seus titulares a conduta "reunir-se pacificamente, sem armas". Assim, necessário se faz avaliar se se trata de uma reunião no sentido do dispositivo constitucional e se a reunião cumpriu a determinação do modo de seu transcurso permitido e protegido como direito fundamental: "pacificamente" e "sem armas".

\subsubsection{Da área de regulamentação do art. $5^{\circ}$ XVI CF: presença de uma "reunião"}

Como reunião, no sentido do art. $5^{\circ}$, XVI CF entende-se a junção de uma pluralidade de pessoas, em um determinado local, em prol de um propósito comum. Para se verificar a presença de uma reunião no mesmo sentido constitucional não importa se a pluralidade de pessoas permanecerá no determinado local ou se se deslocará, adquirindo as nuances de passeata ou marcha. Quanto ao tamanho da pluralidade, não há consenso se são necessárias três ou se bastariam apenas duas pessoas, ${ }^{98}$ mas, no caso em tela, envolvendo $\mathbf{B}$ e mais 10 acompanhantes, está presente, sem dúvidas, um número suficiente de pessoas.

Tratava-se, outrossim, de um discurso de oposição ao evento de campanha eleitoral do Partido Z. Está presente o conceitualmente imprescindível propósito comum, notadamente porque B e as demais pessoas que se dirigiram ao local em comento encontravam-se intrínseca e interdependentemente conectadas pelo propósito comungado. Ao lado de outras instituições políticas, os partidos políticos atuam junto à percepção e à configuração da vontade popular (art. 17 CF). ${ }^{99}$ Sua atuação na campanha eleitoral é formalmente orientada à formação da opinião pública, que terá o condão de instruir futuros processos legislativos e ações governamentais. Nada diferente vale para o

\footnotetext{
97 Sobre o método e esquema de argumentação vide Dimoulis e Martins (2014, p. 129-175, 233-256). A discussão jurídica lusitana costuma se aproximar de maneira mais consequente desse método de exame de possíveis violações. Cf., por exemplo, com nuances terminológicas, mas separando bem conteúdo do direito, de um lado, e seu limites, de outro: SOUSA (2012). Com objetivos comparativos, principalmente da jurisprudência, o que há de ser saudado: (Dias e De Laurentiis, 2014).

98 Cf. por todos: Michael e Morlok (2016, p. 160 e s.).

99 Vide a respeito: Mezzaroba (2014, p. 691). Cf. Schildheuer (2015, p. 231 s.).
} 
discurso de oposição de $\mathbf{B}$, de tal sorte que foram cumpridos até mesmo os requisitos mais estritos endereçados ao conceito de reunião. ${ }^{100}$

\subsubsection{2 “Pacificamente": exclusão de reuniões não pacíficas}

No mais, para que a hipótese de violação do direito fundamental à liberdade de reunião de $\mathbf{B}$ não seja, já nessa fase, corretamente descartada, o que seria o caso se estivesse presente uma reunião que ab initio não esteja contida na área de proteção do $\operatorname{art} .5^{\circ}$, XVI CF a reunião convocada e liderada por $\mathbf{B}$ teria de ter transcorrido pacificamente. Não pacífica é uma reunião que adquirir um transcurso violento ou sedicioso ou que esteja na iminência de adquiri-lo. ${ }^{101}$

\subsection{Interpretação do propósito da reunião convocada por B}

No caso em pauta, o caráter não pacífico da reunião convocada por B poderia, primeiro, resultar do fato de ela ter atrapalhado outra reunião - a campanha eleitoral do Partido Z, supostamente (pois não há elementos fáticos apresentados no caso que o comprovem) anteriormente convocada para o mesmo local. Contudo, um simples incômodo causado por $\mathbf{B}$ e seus comanifestantes infligido a outra reunião não basta para já se negar o atingimento da área de proteção do seu direito fundamental decorrente do art. $5^{\circ}$, XVI CF. ${ }^{102}$

Em que medida e de que modo específico o constituinte pretendeu com a locução "desde que não frustrem outra reunião anteriormente convocada para o mesmo local" excluir reuniões não agendadas, não anunciadas e não comunicadas à (a qualquer que seja) autoridade competente e, faticamente, conflitantes ou impeditivas entre si em termos territoriais, não resta claro. Também não se sabe a partir de que momento uma reunião estaria frustrando outra anteriormente convocada para o mesmo local. Resta tão somente claro que, dogmaticamente, ao contrário da locução "pacificamente, sem armas", a qual implica uma obrigação apriorística dos manifestantes e, com isso,

\footnotetext{
${ }_{100}$ Nesse mesmo sentido, cf. Schildheuer (2015, p. 232). Por um conceito mais estrito: Badura (2015, p. 222 s.) com uma consequente exclusão de festas populares tradicionais, eventos de entretenimento como as festas de rua e de massa. Para o autor, para tal efeito pouco importa se "o tipo de música lá dominante expressa um estilo de vida de assim chamadas subculturas ou se corresponde ao gosto da maioria" (BADURA, 2015, 223) em uma alusão direta a uma decisão do TCF alemão sobre as chamadas Love Parade, de um lado, e Fuckparade, de outro (cf. NJW 2001, p. 2459 ss.). Em sentido oposto, e como já referido partindo do conceito mais amplo que contempla aqueles eventos de entretenimento desde que presente o elemento intrínseco da interdependência entre os reunidos, cf. Michael e Morlok (2016, p. 161-165). Também contrário à exclusão de eventos de entretenimento com caráter de comunicação, ainda que simbólico, com referência a uma reunião de adeptos do skate como meio de transporte e a ela conecta reivindicação por seu reconhecimento no código de trânsito do Estado-membro de Nordhein-Westfallen, posicionou-se Schulze-Fielitz (2013, p. 1037- s. e 1038), em seus comentários ao art. 8 GG.

101 São os dois critérios desenvolvidos no direito comparado alemão pela jurisprudência constitucional daquele país e recepcionada pela literatura jurídica especializada que a acompanha. Cf. por muitos: Schildheuer (2015, p. 213-215 e 232).

102 Nesse âmbito, também a Lei Federal de Reuniões alemã prevê, em seu $\$ 15$ I BVersG, a possibilidade de se proibir previamente ou de se dissolver uma reunião contrária a outra (Gegendemonstration) a depender do prognóstico da ameaça de perigo à segurança pública. Mas de novo: trata-se de um exame a ser perpetrado na terceira etapa da justificação constitucional a partir da aplicação proporcional dos limites constitucionais e não de uma exclusão da proteção desde o início. Nesse sentido, é que se questionará a intervenção muito grave implícita na proibição prévia da reunião que ao cabo somente restará justificada se "uma dissolução a posteriori não puder ser considerada significativamente possível" (SCHULZE-FIELITZ, 2013, p. 1066).
} 
uma exclusão de condutas que não cumpram esse pré-requisito da área de proteção, a organização do espaço público para o uso ordinário e extraordinário e suas respectivas fiscalizações cabem, em regra, ao Poder Público, que deve prevenir perigos e riscos em geral à ordem e à segurança públicas. ${ }^{103}$ Faz, portanto, parte de limites constitucionais a serem concretamente traçados pelo Estado. Isso é o que resta ainda mais nítido na interpretação sistemática com a outra locução "sendo apenas exigido prévio aviso a autoridade competente", quando se pensa na finalidade dessa decisão textual do constituinte.

Assim, o fato de a manifestação de $\mathbf{B}$ ter atrapalhado a campanha eleitoral do Partido Z, que, por sua vez, também pode ser considerada uma reunião não diz respeito à sua pertinência ou não à área de proteção, mas, em todo caso, ao âmbito dos limites, a ser adiante analisado (sob 2.3.1). Se esse for o caso, pode-se questionar também se a intervenção policial servia ou não ao propósito do limite, expressamente previsto pelo constituinte, da não frustração de outra reunião. Da descrição dos fatos não se depreende se a reunião do Partido $\mathbf{Z}$ havia ou não sido previamente convocada para o mesmo local.

Nesse contexto, excluída da área de proteção a reunião convocada por $\mathbf{B}$ poderia ser apenas se ela objetivasse, exclusivamente, impedir, contundente e eficazmente, a realização de outra reunião, o que revelaria um caráter notoriamente sedicioso. ${ }^{104}$ Pelos fatos descritos, B e seus acompanhantes queriam, pelo menos também, chamar a atenção dos transeuntes para o seu ponto de vista. Eles ostentaram cartazes, distribuíram panfletos e B fez um discurso de oposição em face do Partido Z. Não está presente uma pura afetação, ou um intencional estorvo, sem nenhuma mensagem própria, que seria o caso, por exemplo, se fossem arremessados objetos ou se os reunidos por $\mathbf{B}$ perpetrassem uma mera sobreposição dos discursos dos membros do Partido $\mathbf{Z}$ com barulho muito alto e intenso, tornando inaudíveis os discursos realizados na reunião do Partido $\mathbf{Z}$.

Portanto, apenas o propósito da reunião de concorrer com a campanha eleitoral do Partido $\mathbf{Z}$ não representa um caráter não pacífico da reunião de $\mathbf{B}{ }^{105}$

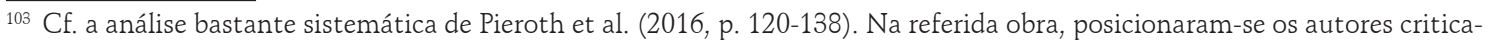
mente no que concerne à compreensão clássica do bem jurídico "ordem pública" como "o conjunto das regras não escritas para o comportamento do indivíduo encontradas no quadro da ordem constitucional, cuja observância [é] pressuposto indispensável de uma convivência dos cidadãos [que possa ser considerada bem] ordenada consoante as concepções respectivamente dominantes." (PIEROTH et al., 2016, p. 133 s.; crítica: p. 134-136). O problema dessa definição reside - além de sua falta de determinabilidade/taxatividade - no seu embasamento nas concepções respectivamente dominantes, razão pela qual os autores citados não reconhecem sua suficiência como bem jurídico constitucional potencialmente legitimador de medidas interventivas e ressaltam a proeminência da segurança pública sobre a ordem pública. Com efeito, embasar em concepções dominantes o que deva ser boa ou salutar convivência, derivando regras de comportamentos não escritas, dificilmente coadunar-se-ia com o significado dogmático dos direitos fundamentais como normas potencialmente legitimadoras de decisões judiciais contramajoritárias.

104 Assim também: Schildheuer (2015, p. 232). No mais, opinião amplamente majoritária na literatura jurídica especializada e na jurisprudência alemãs: Tölle (2017, p. 653 c.c. 709), Götz e Geis (2017, p. 267), Gusy (2014, p. 269 s.) e Schenke (2016, p. 237).

${ }_{105}$ É no livre market place of ideas que opera a liberdade de reunião. O Estado não pode optar pela garantia de um transcurso livre de quaisquer estorvos provenientes de outros titulares do mesmo direito fundamental sob pena de comprometer seu dever de neutralidade ética. Poder-se-ia pensar na aplicação do "princípio da prioridade" a ser dada à manifestação que primeiro ocupar certo espaço. Nesse sentido, cf. Koll (2015, p. 247-352). Porém, esse princípio, também segundo Koll (2015, p. 348), não dispensa uma detida análise da situação concreta pelos agentes públicos. Caso contrário, ele levaria em regra à limitação
} 


\subsection{Comportamento de B em face dos policiais}

Não pacífico poderia ter sido, todavia, o comportamento de $\mathbf{B}$ e de dois de seus colitigantes de causa em face do policial P1 e de seus comandados. De fato, desenvolveram-se "cenas de tumulto" quando B, com veemência e após a reiterada recusa a entregar o alto-falante usado para fazer seu discurso de oposição em face do Partido $\mathbf{Z}$, resistiu à condução coercitiva à viatura policial, desferindo as expressões ofensivas "porcos imundos" e "escravos do sistema" em face dos mesmos policiais. Tumulto generalizado corresponde ao caráter sedicioso, que marcaria uma dada reunião como não pacífica. ${ }^{106}$ Contudo, decisivo para essa avaliação é que a reunião estava pacífica no momento em que começou a medida interventiva na área de proteção, ou seja, tinha sido pacífica até a detenção de B. Com efeito, as "cenas de tumulto" desenvolveram-se apenas após o ensejo para a detenção e em seu transcurso. Pode ser deixado de lado o questionamento de se a tentativa em si de impedir a condução coercitiva sobrepujara a fronteira para o caráter não pacífico. ${ }^{107}$ É o que se faz independentemente dos exames especificamente jurídico-penais relativos à presença dos elementos típicos, presença de culpa ou dolo, etc., os quais também devem ser avaliados apenas na etapa do exame da possível justificação constitucional da intervenção estatal a partir da verificação dos limites do direito fundamental. De resto, a proteção da liberdade de reunião como um todo teria permanecido vigente, em princípio, mesmo se alguns manifestantes ou uma minoria - no caso $\mathbf{B}$ e dois colitigantes de causa em relação às demais oito pessoas - tivessem de fato cometido abusos no transcurso da reunião. ${ }^{108}$ Sem embargo, como $\mathbf{B}$ era o líder da manifestação, aquele que discursava em nome dos demais manifestantes, sua presença é elemento constitutivo relevante ao exercício da liberdade de reunião dos demais titulares do direito fundamental. Exceto se estiver presente o caráter sedicioso, que não pôde ser verificado, $\mathbf{B}$ e os demais reunidos têm uma pretensão jusfundamental, decorrente do art. $5^{\circ}$, XVI CF à autodeterminação quanto à duração da reunião. A contrário senso, devem ser as medidas estatais, como a medida policial em comento, que encurtem uma reunião, interrompendo-a ou dissolvendo-a, consideradas intervenções submetidas ao ônus argumentativo pertinente a terceira principal etapa do exame, que é a da justificação constitucional.

\footnotetext{
apenas da manifestação contrária, visto que estas são "igualmente importantes e dignas de proteção como as primeiras." (KOLL, 2015, p. 349).

106 Nesse sentido, cf. Schildheuer (2015, p. 232).

107 Tangencia-se, aqui, pontualmente, a fronteira da desobediência civil, discussão que, no contexto da liberdade de reunião, tem se revelado assaz hipertrofiada. O que, por vezes, chama-se na discussão pátria de "desobediência civil" cujo reconhecimento normativo não ocorreu no Brasil ao contrário do estipulado pelo art. 20 IV GG (direito à insurreição - Widerstandsrecht) é tão somente um exercício legítimo (e ordinário) de direito fundamental como direito de resistência à intervenção estatal. Assim, faz parte da normalidade do Estado democrático de direito e não do regime de exceção pontual sugerido pelo conceito de desobediência civil. A respeito, v. dentre os comentários ao art. 20 IV GG, representativo: Jarass (2011, p. 538 s.).

${ }^{108}$ Como já anteriormente verificado, cf. referências à nota 79.
} 


\subsubsection{3 "Sem armas"}

Armas são todos os objetos que, com o devido uso, sejam idôneos a ferir pessoas ou a substancialmente danificar coisas. ${ }^{109}$ Como arma pode ser trazida à pauta, em todo caso, o alto-falante de B. Certamente, um ataque com um alto-falante nas mãos pode causar ferimentos. Contudo, para não tornar o conceito de armas tão sem contornos minimamente rígidos e, por consequência, de maneira quase ilimitada, extensível a objetos do cotidiano, deve-se exigir ao menos uma propensão ao uso por parte de quem os porte. ${ }^{110}$

B trouxe consigo para a reunião seu alto-falante, notoriamente não com a finalidade de usá-lo como arma, mas tendo em vista o propósito original do objeto, que é o de dar amplificação sonora à própria voz. No mais, ele, de fato, não utilizou o alto-falante, em nenhum momento, como arma.

\subsubsection{4 "Em locais abertos ao público"}

Protegidas são as reuniões abertas ao público. Deduzir que reuniões fechadas ao público não fossem protegidas por direito fundamental tornaria desprotegidas reuniões que têm menor potencial de colisão com outros bens jurídicos. Seria, no mínimo, uma interpretação hostil a liberdades individuais. Não é o caso. Ocorre que reuniões a portas fechadas ou já restam protegidas por outros direitos fundamentais, ou o constituinte mencionou apenas reuniões realizadas em locais abertos ao público para relacioná-las com a exclusão a priori das reuniões não pacíficas feitas ao ar livre e/ou para relacioná-las com os limites a serem discutidos adiante. Por fim, considerando o sequenciamento de várias locuções adverbiais intercaladas por vírgulas que marca o teor do art. $5^{\circ}$, XVI CF uma interpretação possível seria que a locução ora epigrafada baseie-se, em primeira linha, na locução adverbial "independentemente de autorização", visto que a contrário senso dependeriam de autorização as reuniões realizadas em locais fechados ao público. ${ }^{111}$

Reuniões em locais abertos ao público são aquelas que podem se expandir para todos os lados, de acesso geral a qualquer interessado, portanto. ${ }^{112}$ Faz parte da liberdade de reunião, em prin-

\footnotetext{
109 Alguns autores incluem no rol das armas no sentido constitucional em pauta também armas "aparentes", destacando o papel da ameaça. As chamadas "armas passivas" (objetos de proteção como capacetes, máscaras de gás ou capas) não são armas. Contudo, a depender do caso, podem indiciar uma tendência não pacífica da reunião. Cf. nesse sentido: Hufen (2016, p. 486).

110 Cf. Michael e Morlok (2016, p. 167). Somente no caso de porte de armas tradicionais como revólver, armas brancas e soco inglês não há, em geral (exceção para o caso de manifestações pacíficas de servidores públicos da área da segurança pública), necessidade de se comprovar o propósito do uso. Em todo caso, objetos que ofereçam risco representam ao menos um indício da outra condição para exclusão da proteção, que é o caráter não pacífico. Cf. Jarass (2016, p. 298) e Schulze-Fielitz (2013, p. 1044 s.).

111 Para um aprofundamento que aqui não é relevante para os efeitos da tarefa do presente parecer sobre uma específica hipótese de violação do art. $5^{\circ}$, XVI CF, vide a discussão já feita na seção 3.1.3, cujo objeto foi a apresentação do alcance abstrato da tutela, especialmente o texto acompanhado pelas notas 89 e 90 .

112 Cf. por todos: Schildheuer (2015, p. 219).
} 
cípio, a escolha do local de sua realização, do trajeto em caso de passeata ou marcha, dos horários de início e fim, de todos os preparativos prévios e circunstâncias da reunião. ${ }^{113}$

No caso em tela, B encontra-se reunido com seus colegas em uma praça pública e, com isso, em um local "aberto ao público".

O fato de ele ter-se valido da liberdade de reunião para apresentar uma opinião hostil, v.g. de severa oposição ao Partido Z, naquele local e naquelas circunstâncias, não retira o cumprimento da precondição do caráter pacífico da reunião. Pelo contrário, trata-se de uma escolha que cabe somente a ele e aos demais reunidos que se encontram - como introdutoriamente verificado - intrinsecamente unidos por esse propósito em face do qual são interdependentes.

Por isso, trata-se de um comportamento que faz parte da área de proteção do direito fundamental à liberdade de reunião. Assim como também fazem parte da sua área de proteção a escolha da realização da reunião naquele específico local, o ensejo e a motivação de apresentar uma contundente contramanifestação discursiva em face do comício eleitoral do Partido $\mathbf{Z}$, além do respectivo lapso temporal pelos reunidos autodeterminado. ${ }^{114}$

\subsubsection{Conclusão intermediária}

A proteção jusfundamental do art. $5^{\circ}$, XVI CF abarca, portanto, as condutas descritas de $\mathbf{B}$ e dos demais reunidos. Consequentemente, eventuais restrições perpetradas por medidas caracterizadoras de intervenção estatal deverão passar no crivo da justificação constitucional com pauta nos limites ao direito fundamental e no controle de sua aplicação. ${ }^{115}$

\subsubsection{Intervenção estatal}

Segundo o conceito contemporâneo de intervenção estatal, toda redução perceptível da área de proteção de um direito fundamental pode ser entendida como uma intervenção estatal carecedora de justificação constitucional. ${ }^{116}$

B voltou-se contra a condenação a uma pena privativa de liberdade consubstanciada na SC. Assim, foi penalmente sancionado um comportamento protegido pelo art. $5^{\circ}$, XVI CF composto

\footnotetext{
${ }_{113}$ Cf. por todos: Pieroth et al. (2015, p. 201 s.).

114 Contudo, é claro que o lapso temporal pode sofrer restrições (intervenções estatais), figurando no direito comparado alemão como uma importante medida de compatibilização do direito em tela com interesses respaldados, de modo direto ou indireto, na ordem constitucional vigente. Porém, isso não obsta o reconhecimento da abrangência (prima facie) da faculdade jurídico-subjetiva discutida, implicando o já várias vezes mencionado ônus argumentativo de justificação tanto do legislador quanto do intérprete e aplicador das medidas interventivas. As regras de dissolução das reuniões, inclusive daquelas previamente anunciadas e comunicadas aos competentes órgãos de segurança pública, foram definidas também na Lei Federal de Reuniões alemã, em seus $\iint 13$ II, 18 I e 19 BVersG, visto que o primeiro dispositivo para reuniões públicas em locais fechados ( $(13$ II BVersG) tem aplicação analógica nas reuniões em locais abertos ao público estacionárias ou móveis, i.e., na forma de passeatas ou marchas. Cf. Pieroth et al. (2016, p. 387-389).

115 Vide explicações e referências na nota anterior.

116 Cf. Dimoulis e Martins (2014, p. 141-148).
} 
pela intenção e tentativa de $\mathbf{B}$ de continuar participando da reunião na condição de seu líder. Se, de um lado, os fatos provados no processo penal que levaram à SC podem ser, em tese, subsumidos em dispositivos penais, de outro, implicam o seguinte reconhecimento: a medida policial, independentemente de sua caracterização jurídica, excluiu $\mathbf{B}$ de uma reunião que - como verificado - cumpre o pressuposto conceitual e os pré-requisitos examinados. Com isso, atingiu um dos conteúdos elementares $^{117}$ da liberdade de reunião, que é a presença do titular em dada reunião, mais precisamente o engajamento do próprio corpo para a persecução do propósito partilhado pelos demais reunidos. Essa intervenção administrativa da medida policial foi objeto de apreciação do órgão jurisdicional penal e corroborada em SC. Que uma pena privativa de liberdade não é uma bagatela, mas que se trata, ao contrário, de uma sanção bem perceptível, é óbvio. ${ }^{118}$ Disso resulta uma significativa intensidade da intervenção em apreço a ser levada em especial consideração na fase da aplicação do "limite do limite" constitucional ao direito fundamental, especificamente na aplicação do subcritério do critério da proporcionalidade.

Logo, está presente uma intervenção estatal na área de proteção do direito fundamental de $\mathbf{B}$ à liberdade de reunião.

\subsubsection{Justificação constitucional}

A intervenção restaria, no entanto, justificada, se ela estivesse coberta por um limite constitucional previsto pelo constituinte à liberdade de reunião do art. 5 XVI CF.119

\subsubsection{Limites constitucionais ao art. $5^{\circ}, \mathbf{X V I}$ CF}

\subsubsection{1 "Prévio aviso a autoridade competente" como reserva legal imperfeita ou tácita?}

Quando o constituinte estipulou, no art. 5 XVI CF prévio aviso a autoridade competente, apesar de o direito poder ser exercido "independentemente de autorização", notoriamente intencionou estabelecer um limite ao direito fundamental para compatibilizá-lo com outros bens jurídicos relevantes, que restariam ameaçados por um exercício ilimitado da liberdade em comento. Tivesse o constituinte mencionado a lei, ter-se-ia uma reserva legal simples como a prevista no art. 8

\footnotetext{
$\overline{117}$ Não se deve confundir o uso do adjetivo aqui com a malfadada teoria do conteúdo ou núcleo essencial dos direitos fundamentais que, na Alemanha, passou por um processo de completa assimilação pelo princípio e critério da proporcionalidade, pelo menos do ponto de vista prático, que é o que aqui interessa. Cf., por todos: Dreier (2013b, 1723, 1726). No presente contexto, elementar significa aqui nítido, recorrente, mais consolidado, mais óbvio. Por sua vez, na discussão brasileira fez uma carreira errática - a exemplo, diga-se, do ocorrido com o princípio da dignidade humana, a despeito do supremo significado deste, transformando-se em chavão para as abordagens mais superficiais.

118 Cf., neste mesmo sentido: Schildheuer (2015, p. 216).

119 Cf., em geral, sobre a exigibilidade e o processo de justificação constitucional de intervenções estatais em direitos fundamentais, novamente: Dimoulis e Martins (2014, p. 151 ss.).
} 
II Grundgesetz. ${ }^{120}$ Como não o fez, tem-se uma reserva legal imperfeita ou tácita. Isso porque todas as normativas pertinentes a esse prévio aviso devem ser, por força do princípio da legalidade e da essencialidade, ${ }^{121}$ definidas, pelo menos em linhas gerais, pela lei ordinária, devendo e podendo ser objeto de lei em sentido material editada por entes administrativos apenas as questões mais detalhadas.

Como não se tem uma lei configuradora, a exigência de prévio aviso prevista pelo constituinte é inexigível pela Administração por total falta de fundamento legal. Uma imposição por órgãos administrativos violaria os mais elementares princípios pertinentes ao princípio-matriz do Estado de direito lastreado no art. $1^{\circ}$, caput CF (confiança, determinabilidade, previsibilidade, etc.). ${ }^{122}$ No mais, os autores que entendem tais locuções como predeterminantes de um modo de exercício, único permitido, com a consequente exclusão a priori da proteção em se não os atendendo e, destarte, como cláusulas destinadas aos titulares do direito fundamental e não aos órgãos titulares das três funções estatais clássicas e que, por conseguinte, defendem a "autoaplicabilidade" do dispositivo permanecem devedores da seguinte explicação. Como coadunar a exigibilidade imediata - i.e., sem interposição legal - do prévio aviso, com a expressa dispensa de uma autorização no plano normativo das consequências jurídicas? Ou afinal, qual seria a consequência jurídica da ausência de um prévio aviso a autoridade competente, seja esta quem for? O suporte fático da norma somente faz sentido se se perpetra, como feito aqui, a cisão entre o suporte fático jusfundamental stricto sensu ("todos podem reunir-se, pacificamente, sem armas, independentemente de autorização, em locais abertos ao público") e o suporte fático do limite ao mesmo direito fundamental ("desde que não frustrem outra reunião anteriormente convocada para o mesmo local, sendo apenas exigido prévio aviso a autoridade competente"). Caso contrário, o intérprete não teria diante de si uma norma jurídica (constituída, pelo menos, de um suporte fático acrescido de uma consequência jurídica), mas tão somente uma mera proclamação ou, na melhor das hipóteses, uma muito vaga e não vinculante diretriz.

Segundo a descrição do caso, P não escorou sua ordem de entrega do alto-falante na suposta ausência de prévio aviso, sem prejuízo da conclusão quanto à inexigibilidade sem lastro legal. Logo, a medida de $\mathbf{P}$, corroborada judicialmente em $\mathbf{S C}$, não encontra - e não poderia encontrar por ausência de autorização legal - respaldo nesse limite constitucional.

\footnotetext{
$\overline{120 \text { Segundo o Art. } 8}$ II Grundgesetz: "Para reuniões ao ar livre, esse direito pode ser restringido por intermédio de lei ou com base em uma lei".

${ }^{121}$ Segundo o último, as questões essenciais pertinentes aos pressupostos da intervenção devem ser definidas diretamente pelo legislador formal, caso em que a reserva legal reveste-se de reserva "parlamentar". A respeito, vide Dimoulis e Martins (2014, p. 162 s.).

122 Trata-se de um caso notório de aplicação da teoria da essencialidade. Cf. referência na nota anterior.
} 


\subsection{Direito constitucional colidente?}

Como o direito fundamental à liberdade de reunião não foi outorgado com uma reserva legal, pelo menos não com uma reserva legal expressa, vem à pauta apenas um limite derivado do chamado direito constitucional de colisão. ${ }^{123}$ Trata-se de intervenções que possam estar baseadas em norma constitucional, hipótese em que o órgão interventor teria de estar, para esse efeito, perseguindo a concretização de um bem jurídico constitucional. ${ }^{124}$

No art. $5^{\circ}$, XVI CF o constituinte ressalvou, em princípio, do arbítrio estatal a repressão a reuniões havidas "em locais abertos ao público". Semanticamente, trata-se de proteger as reuniões de acesso público que possam, portanto, expandir-se para os lados. Reuniões fechadas são protegidas pela Constituição Federal a partir de outros direitos fundamentais. ${ }^{125}$

No caso em tela, a reunião de B foi realizada em uma praça pública. Logo, faz parte, como visto, da área de proteção do art. $5^{\circ}$, XVI CF.

Não obstante, as reuniões efetivamente realizadas em locais abertos ao público podem, de fato, chocar-se com outros bens jurídico-constitucionais, comprometendo-os. Por isso, o constituinte estipulou um limite constitucional qualificado, ainda que, tecnicamente, não se possa falar em reserva legal por não ter mencionado a lei. Desse modo, delegou ao legislador ordinário a competência para prever aquelas restrições à liberdade de reunião que tenham o condão de proteger alguns bens jurídico-constitucionais contra seus exercícios "abusivos". 126

As locuções "desde que não frustrem outra reunião convocada para o mesmo local" e "sendo apenas exigido prévio aviso a autoridade competente" apresentam, tacitamente, autorizações para pontuais intervenções. Todavia, tais pontuais intervenções deveriam ser, primeiro e como já aludido, atualizadas pelo legislador ordinário, considerando o princípio da legalidade e da essencialidade da definição parlamentar (reserva parlamentar) de pressupostos gerais ${ }^{127}$ para intervenções executivo-administrativas e judiciais no exercício mais amplo do direito fundamental em tela.

Como bem jurídico-constitucional que, em princípio, motivou a intervenção policial corroborada por $\mathbf{S C}$, vem à pauta a garantia da capacidade funcional128 do órgão da polícia que, por sua vez, atuava no sentido de garantir que outra reunião convocada para o mesmo local - mais precisamente, para um local contíguo à outra já em curso - pudesse ser concluída sem estorvos. Esse bem jurídico-constitucional representa o lastro constitucional dos art. 329 e 331 do Código Penal

\footnotetext{
$\overline{123}$ Cf., em geral, sobre esse tipo de limite constitucional a direitos fundamentais: Dimoulis e Martins (2014, p. 163-169).

124 O problema da interpretação e aplicação dessa espécie de limite constitucional na ordem constitucional brasileira é o caráter muito analítico, prolixo, do sistema normativo-constitucional positivado na CF. Gera dificuldades a possibilidade muito ampla de se encontrar respaldo positivo-constitucional para a tutela dos mais diversos interesses e bens jurídicos que, em outras ordens constitucionais de perfil ocidental democrático, não encontram respaldo direto no Texto Constitucional.

${ }^{125}$ Cf. as discussões já feitas no texto e as respectivas referências às notas 89, 90 e 111.

${ }^{126}$ É o legislador ordinário quem define o que deva ser considerado exercício abusivo de direito fundamental, implicando tal definição uma intervenção estatal legislativa a ser justificada constitucionalmente.

127 Cf. já no texto anterior e suas respectivas referências à nota 117.

128 Cf. definição e referências à nota 87.
} 
Brasileiro (CPB), ${ }^{129}$ que foram interpretados e aplicados pelo Poder Judiciário, e que deu fundamento à condenação pela $\mathbf{S C}$.

As tipificações e respectivas penas privativas de liberdade têm por escopo proteger a "Administração em geral contra crimes praticados por particular". 130 Assim é a epígrafe dada ao capítulo em que se inserem os dois tipos em comento pelo próprio legislador penal brasileiro. Esse bem jurídico tutelado ao nível da legislação penal ordinária representa uma possível configuração infraconstitucional dos bens jurídico-constitucionais protegidos pelo art. 144, caput CF: "preservação da ordem pública e da incolumidade das pessoas e do patrimônio", na medida em que nele se busca assegurar as condições objetivas mínimas para que os agentes policiais combatam os perigos, notoriamente, aqueles perigos concretos advindos de aglomerações de pessoas que sejam potencialmente ofensivos a ordem e segurança públicas. ${ }^{131}$ Exemplo dos mais eloquentes é a necessidade de se

\footnotetext{
129 Sobre a interpretação e aplicação de tipos penais abertos como os dos art. 329 e 331 do CPB: Prado (2010, p. 566-568) e Nucci (2009, p. 1031). Da literatura mais antiga, v. Jesus (1997, p. 208). Denuncia uma suposta omissão do legislador penal junto às definições dos tipos dos crimes de resistência e desacato, Bitencourt (2010, p. 198, 216-218): no tipo penal da resistência faltaria segundo ele uma distinção entre "legalidade manifesta" e "legalidade duvidosa". Por sua vez, no tipo normativo do crime de desacato haveria um comprometimento da "liberdade de manifestação". O indivíduo seria levado pelas circunstâncias criadas pelo próprio agente público a cometer o crime de desacato, mais recorrentemente nos âmbitos policial e judicial, agentes estes que estariam sujeitos mais intensamente à crítica enérgica voltada à sua atuação como servidor do Estado (BITTENCOURT, 2010, p. 198, 206, 217-218). Sem dúvida: policiais e juízes, não apenas como servidores públicos que são, mas também como detentores de poderes e competências cerceadoras das liberdades fundamentais dotadas de supremacia normativa, encontram-se submetidos de maneira no mínimo tão rigorosa às normas em geral e especiais, v.g. no caso da tipificação do crime de prevaricação até mais intensa do que o são estrangeiros residentes no país em geral e cidadãos não servidores. Mas a argumentação referida realiza-se na melhor das hipóteses de lege ferenda, não se podendo rechaçar uma norma já abstratamente como inconstitucional sem o devido exame a que se propõe a presente contribuição. Há de se, pelo contrário, primeiro, bem delinear o bem jurídico protegido pelos art. 329 e 331 do CPB, verificar se se trata de propósitos lícitos em princípio correspondentes a limites a direitos fundamentais, que foram muito vagamente aludidos pelo citado autor. Em seguida, questiona-se se sua promoção via norma penal abstrata (especificamente junto a configuração do tipo penal) e se junto a sua interpretação e aplicação, respectivamente, observou-se o critério da proporcionalidade. Caso contrário, estar-se-ia substituindo o juízo de valor do legislador penal - funcional e democraticamente legitimado pela CF para tanto - pelo juízo de valor do intérprete e aplicador que, por princípio, deve observá-lo. Com base no parâmetro do art. 13 da CADH, manifestou-se o STJ pela inconvencionalidade do art. 331 do CPB, cf. STJ-Rec. Esp. 1.640.084-SP (Rel. Min. Ribeiro Dantas), de 2015, com frágeis, vagos e meramente retóricos ("tendência humanista") fundamentos marcados por problemas muito semelhantes aos apontados.

${ }^{130}$ No correspondente tipo do $\ 113$ StGB, i.e., do código penal alemão, intitulado "insurreição contra funcionários públicos de execução", positivado sob a Seção VI, intitulada "insurreição contra o poder estatal", o bem jurídico protegido é, segundo Bosch (2017, p. 443), o "poder executivo do Estado, licitamente exercido". Todavia, o código penal alemão ora trazido à pauta previu em um dos parágrafos do dispositivo penal ( $\$ 113$, III 1 StGB) - que, de resto, é muito detalhado - que "a conduta não será punível segundo esta norma se o ato do servidor não for lícito." Por seu turno, fala-se, na discussão pátria, na defesa do "princípio da autoridade e [do] prestígio da função, condições primaciais para a atuação regular e normal da administração pública e defesa dos direitos individuais." (NORONHA, 1998, p. 303). No mesmo sentido, cf. Capes e Prado (2014, p. 663). Essa definição do propósito do legislador penal com a tipificação dos crimes de resistência, desobediência e desacato, como sendo a defesa do "princípio da autoridade" e do "prestígio da função" merece uma decidida e rigorosa objeção. No primeiro caso, porque mesmo ou especialmente na interpretação de normas penais tem primazia o princípio da liberdade e não da autoridade. É o que determina o aqui consequentemente aplicado princípio distributivo dos ônus de justificação entre o Estado e os indivíduos submetidos ao seu "poder de império". No segundo caso, da definição do propósito das normas penais em tela como sendo o "prestígio da função". Admitindo-se que houvesse no Brasil, o que notoriamente não é o caso, estrita separação entre a investidura pública e os particulares nela investidos, poder-se-ia, porém, ainda assim, com muitas reservas, falar-se em "prestígio da função". De constitutione ferenda, no contexto da apreciação do instituto da prerrogativa de foro, esta poderia ser reservada apenas ao chefe de Estado e de governo, o que seria mais condizente com os princípios constitucionais democrático e até o republicano. Como "prestígio da função" no Brasil muito rapidamente redunda em privilégios de agentes públicos, não há como considerar que tal seja o propósito licitamente perseguido pelo legislador penal.

${ }^{131}$ Ordem pública é um conceito jurídico indeterminado que pode dar azo a decisões e medidas autoritárias porque não cumpridoras do ônus argumentativo da justificação constitucional da imposição de limites a direitos fundamentais. Na discussão comparada alemã, ela é tratada de maneira bem distinta do bem jurídico constitucional da segurança pública, como visto ligado ao combate a perigos classificáveis, entre outros, pelas categorias dos perigos abstratos e concretos. Ordem pública lá
} 
responder imediatamente aos perigos do encontro planejado ou não de dois grupos numericamente relevantes e ideologicamente rivais. ${ }^{132} \mathrm{Nada}$ obstante, assim como no caso em tela, a contramanifestação é abrangida pela área de proteção da liberdade de reunião, razão pela qual os prognósticos das autoridades policiais devem cumprir seu ônus argumentativo orientado pelo critério técnico-jurídico constitucional da proporcionalidade. ${ }^{133}$

Está presente, portanto, um limite traçado pelo legislador e órgãos que o interpretam e aplicam que é configurador, ao nível da legislação ordinária infraconstitucional, de um bem jurídico-constitucional. Destarte, trata-se da confirmação da hipótese de direito constitucional colidente. ${ }^{134}$

é definida como conjunto de normas não escritas, amparadas em uma concepção majoritária do que deva ser elementar para uma agradável convivência coletiva. Ocorre que perseguir um estado de coisas que é agradável para a maioria não pode ser considerado um propósito diretamente lastreado no sistema constitucional em sentido estrito. Nesse sentido, os conceitos do binômio ordem pública/segurança pública do art. 144 CF deveriam ser tratados como sinônimos; o conceito de segurança pública no sentido exposto de combate a perigos assimilaria o de ordem pública. Cf. sobre as origens do conceito na jurisprudência do Tribunal Superior Administrativo da Prússia: Pieroth et al. (2016, p. 133 s.) e a crítica dos mesmos autores ao conceito em face de sua elevada influenciabilidade ideológica: Pieroth et al. (2016, p. 134-135).

${ }^{132}$ No direito comparado alemão, há divisão muito clara de tarefas entre as repartições públicas competentes para a gestão da segurança pública e a polícia. As primeiras têm competências pertinentes a lapsos temporais que antecedem uma reunião convocada e a elas comunicadas com vistas ao procedimento de aviso ou inscrição e para a edição de obrigações a serem adimplidas pela organização e lideranças da anunciada reunião. Recai em sua competência também a proibição preventiva da reunião sem prejuízo obviamente da abertura da via judicial administrativa. Por outro lado, ainda no momento prévio à reunião, a polícia é competente para a tomada de medidas relativas ao deslocamento e chegada de manifestantes ao local, principalmente quando se espera um público que transcenda fronteiras municipais. Depois do início da reunião, as competências são mais claramente divididas entre as aludidas repartições e a polícia. As primeiras mantêm a competência para determinar a dissolução, mas os órgãos policiais têm uma pletora de competências originais. Estas são todas relativas ao combate a perigos concretos verificados durante a realização da reunião. Cf. a apresentação panorâmica de Götz e Geiz (2017, p. 262 s.), autores de um curso de "Direito Geral de Polícia e Ordem", na tradução literal, que vem formando gerações de juristas desde sua primeira edição em 1970 (ao lado de mais de uma dezena de exposições monográficas voltadas ao curso de graduação em direito, como disciplina curricular obrigatória): "Em reuniões aparecem, tipicamente, um grande número de pessoas que defendem uma opinião comum e que querem influenciar outras pessoas, razão pela qual elas carregam um especialmente elevado potencial de conflito. $O$ direito de reunião tem no caso uma delicada dupla função: de um lado, precisa realizar a liberdade de reunião [infraconstitucionalmente perante os órgãos administrativos, inclusive a polícia], garantida pelo art. 8 GG; de outro lado, precisa proteger também outras pessoas que sejam atingidas justamente por um extrapolamento dessa liberdade." (GÖTZ; GEIZ, 2017, p. 262). No procedimento legalmente previsto para o aviso, que pode resultar até mesmo na proibição prévia e cuja constitucionalidade em face do art. 8 I GG sempre retorna aos debates, tem como fio condutor a cooperação entre organizadores e líderes da reunião, de um lado, e repartições públicas e polícia, de outro. A lei nunca foi rechaçada como inconstitucional porque tanto a jurisprudência quanto a literatura especializada fazem reduções das margens discricionárias abertas pela lei ao controlar seu uso no momento da interpretação e aplicação. Gusy (2014, p. 259-264) fala, nesse contexto, em "reunião organizada" ("o direito de reunião legal: a reunião organizada") e sob essa epígrafe de um tópico de seu curso em "princípio da cooperação no direito de reunião" (GUZY, 2014, p. 261) e em "dialogo cooperativo". Nesse sentido também: Schenke (2016, p. 242) citando a Decisão Brokdorf do TCF (BVerfGE 69, 315), enfatizando que tal cooperação é ainda mais importante por ocasião de grandes manifestações. Tölle (2017, p. 662-665) esmiúça muito bem o princípio cooperativo, esclarecendo que é constituído pela oferta da cooperação pelo competente órgão da Administração Pública competente, entendido como "fiador da liberdade de reunião" e o comportamento cooperativo do organizador. Nesse sentido, seria obrigação do órgão competente oferecer a cooperação, enquanto o organizador não poderia ser obrigado a ela com cominação de pena pecuniária. Contudo, uma "recusa de cooperação pode ser parte de um prognóstico de perigo e justificar restrições ou uma proibição." (TÖLLE, 2017, p. 665).

${ }_{133}$ Cf. a respeito de maneira muito consequente nesse sentido: Koll (2015, p. 345-259).

${ }^{134}$ A descrição dos fatos incontroversos, objeto do presente parecer, revela que a conduta de $\mathbf{B}$ relativa às expressões ofensivas dirigidas a $\mathbf{P}$ poderia configurar crime de injúria (art. $140 \mathrm{CPB}$ ). Sem entrar no mérito especificamente da dogmática jurídico- penal por extrapolar o objeto do presente parecer e que, por isso, pode ser deixada de lado aqui, certo é que, do ponto de vista constitucional, toda a abordagem teria de ser outra: estaria aberta em tese a área de proteção do direito fundamental concorrente da liberdade de reunião, qual seja, à livre manifestação do pensamento do art. $5^{\circ}$, IV CF dando-se a intervenção nesse outro direito, outorgado com outros limites (ao invés do direito constitucional colidente do art. 144 CF, limite constitucional seria o direito fundamental à honra do art. $5^{\circ}, \mathrm{X}$ CF) e diferentes pressupostos para sua justificação constitucional. 


\subsection{Conclusão intermediária}

Presente está, portanto, um limite decorrente de direito constitucional colidente (art. 144, caput CF). Não obstante, cabe investigar, a seguir, se tal limite foi traçado de maneira a respeitar os limites derivados da outorga original do direito fundamental (limites dos limites).

\subsubsection{Limites dos limites: proporcionalidade da lei penal aplicada e sua interpretação orientada pelo direito fundamental atingido}

Por sua vez, para a justificação final da intervenção judicial em SC, a lei aplicada precisaria ter cumprido dois requisitos que devem ser avaliados sequencialmente. Primeiro, ela precisaria ser, em si, compatível com a Constituição, notadamente com o art. 5 XVI CF. Além disso, no caso concreto, ela teria de ser interpretada e aplicada de modo constitucionalmente compatível. É o caso da incidência de uma interpretação orientada por direito fundamental, como subespécie da chamada "interpretação conforme a Constituição". ${ }^{135}$

\subsection{Constitucionalidade dos dispositivos penais aplicados: proporcionalidade da intervenção legislativa}

Para a aferição final da constitucionalidade da imposição do limite por lei, questiona-se sua proporcionalidade. ${ }^{136}$ Para o alcance do propósito lícito da garantia da capacidade funcional dos órgãos da polícia em face de sua tarefa constitucional determinada pelo art. 144, caput CF os dispositivos penais dos art. 329 e 331 do CPB, como meios de intervenção em vários direitos fundamentais, em que se inclui também o direito fundamental à liberdade de reunião do art. $5^{\circ}$, XVI CF, sendo em si lícitos, são também indubitavelmente adequados. A cominação penal das condutas tipificadas desestimulam, em geral, sua prática. Isso é o que corresponde à situação almejada, tal qual implícita no limite constitucional à liberdade de reunião consubstanciado no art. 144, caput da CF. Há uma conexão fundada em hipóteses comprovadas sobre a realidade empírica entre a situação conseguida mediante a aplicação do meio de intervenção e o estado de coisas almejado. Em outras palavras, tem-se um prognóstico empiricamente comprovado ou, pelo menos, ainda não validamente refutado. ${ }^{137}$

\footnotetext{
135 Sobre a figura tão mal recepcionada da discussão jurisprudencial e jurídico-científica alemã: Martins (2011, p. 60 s., 100 s). A diferença entre a interpretação conforme a Constituição e a interpretação orientada pela Constituição / por direitos fundamentais consiste no respectivo âmbito de incidência e no principal destinatário vinculado ao direito fundamental que, respectivamente, marcam a interpretação do objeto do controle de constitucionalidade: a primeira atua no controle normativo abstrato, de tal sorte que, em havendo mais de uma interpretação possível da norma submetida ao controle, escolhe-se a que for compatível com o parâmetro constitucional, poupando a norma de uma declaração de inconstitucionalidade; a segunda recai sobre a interpretação e aplicação judicial de norma, que deve ocorrer à luz do direito fundamental, visando, portanto, ao controle específico da instância judicial e não mais apenas do legislador. Nesse sentido, cf. Schlaich e Korioth (2015, p. 321 s.). ${ }^{136}$ Cf. em detalhes e com aprofundamento teórico: Dimoulis e Martins (2014, p. 167-169, 176-229).

${ }^{137}$ A despeito de todo ceticismo em torno da eficácia social preventiva da cominação penal de condutas (efeito de desestímulo, prevenção geral), goza o legislador de duas prerrogativas em face da engenharia funcional constitucional: a primeira é de
} 
No mais, não se vislumbra alternativa adequada que fosse, entretanto, menos onerosa no horizonte dos meios de intervenção disponíveis ou imagináveis. Assim, eles são também necessários. ${ }^{138}$

Logo, não recaem dúvidas quanto à constitucionalidade das normas penais em si que embasaram a intervenção judicial consubstanciada na SC.

\subsection{Compatibilidade da interpretação e aplicação dos art. 329 e 331 do CPB com o art. $5^{\circ}$, XVI CF: interpretação orientada pelo direito fundamental e proporcionalidade da aplicação}

\subsection{Da interpretação orientada pelo direito fundamental do art. $5^{\circ}, \mathrm{XVI}$ CF}

Questionável nesse estágio do exame é se as normas penais trazidas à pauta, as quais fundamentaram a decisão condenatória em SC, foram interpretadas e aplicadas de maneira orientada pelo direito fundamental de $\mathbf{B}$ à liberdade de reunião. Trata-se de avaliar se o Judiciário reconheceu o assim chamado "efeito de irradiação" do direito fundamental, observando completamente seu vínculo ao direito fundamental atingido. ${ }^{139}$

Dúvidas sobre a não observância desse especial limite ao limite do direito fundamental recaem, precipuamente, sobre a proporcionalidade do meio de intervenção judicial implícito na condenação de $\mathbf{B}$ em $\mathbf{S C}$.

Nesse sentido, ambas as normas penais que embasaram SC deveriam ter sido interpretadas e aplicadas à luz do direito fundamental de B. Por isso, o juiz penal deveria ter, primeiro, verificado, como já aqui feito, a pertinência dos fatos e das condutas de particulares à área de proteção do direito fundamental do art. $5^{\circ}$, XVI CF; e, segundo, também como já aqui feito, a correspondente intervenção perpetrada por $\mathbf{P}$ (P1 e seus colegas). Por fim, deveria ter interpretado os eventuais limites constitucionais ao art. $5^{\circ}$, XVI CF que, supostamente, teriam sido aplicados por $\mathbf{P} .{ }^{140}$

\footnotetext{
exclusivamente escolher os propósitos lícitos a serem perseguidos, o que corresponde totalmente a ter uma agenda política a ser seguida. A segunda prerrogativa é de decidir por um prognóstico que, por natureza, é heurístico. Assim, somente falseado o reconhecimento da adequação da cominação da conduta, pode ser ela considerada e declarada inadequada - algo que, no entender do presente autor, acontece, por exemplo, com as tipificações dos crimes relativos à produção, ao comércio e ao consumo de drogas hoje ilícitas e do aborto, independentemente dos propósitos não apenas lícitos perseguidos por tais medidas interventivas no direito fundamental à liberdade geral de ação e no livre desenvolvimento da personalidade, como também ordenados constitucionalmente (respectivamente em primeira linha: saúde pública e proteção da vida humana intrauterina). Vide o exame destes em Martins (2014, p. 98-108; 2015).

${ }^{138}$ Como não se trata de ponto problemático, basta a assertiva sem mais aprofundamentos. Cf., todavia, em sentido oposto, ainda que com pauta na liberdade de manifestação do pensamento pactuada na $\mathrm{CADH}$, em seu art. 13, a anteriormente já criticada decisão do STJ no Rec. Esp. 1.640.084-SP (Rel. Min. Ribeiro Dantas), de 2015. Na técnica e estilo de parecer jurídico, marcados pela literatura jurídica geral alemã, deve ser desenvolvida a sensibilidade para o devido reconhecimento dos problemas, devendo ocorrer a respectiva discussão na exata medida de sua demanda a ser deduzida do problema proposto (do "caso"). Cf. em detalhes: Dimoulis e Martins (2014, p. 233-256).

139 A respeito, v. novamente: Martins (2012-a: 89 e 100-119).

140 O procedimento seguido no controle de constitucionalidade da norma aplicada pela autoridade coatora deve ser novamente seguido no seu controle incidental judicial concreto. Cf. por muitos: Grimm (1995).
} 
Não se depreende da descrição do caso proposto que o juiz tivesse feito esse exame e o apresentado na fundamentação de sua SC. Em se admitindo a ausência do devido exame (ex officio), já poderia ser verificada uma violação por $\mathbf{S C}$ do direito fundamental à liberdade de reunião de $\mathbf{B} .{ }^{141}$ Contudo, como B sustenta por intermédio de seu advogado que em SC o juiz penal julgou uma notoriamente ilícita ação policial contra uma reunião como se lícita fosse e que a ação de $\mathbf{B}$ não seria punível, porque não seria sequer típica, uma vez que a ação policial não foi legal em sentido amplo, parte-se, aqui, da presunção de que o juiz penal em SC fez o exame específico. Isso porque, para ter chegado à conclusão de que a ação policial fora legal, o juiz necessariamente teve de interpretar os elementos típico-normativos pelo menos do art. $329 \mathrm{CPB}$ da resistência, que $\mathbf{B}$ teria oposto à execução de medida "legal". Ainda que o juiz tenha se valido de critérios e exigências menos rigorosas endereçados à característica típica "legal", satisfazendo-se, em vista do bem jurídico protegido, com a mera aparência de legalidade, não teria como ter deixado de considerar a possibilidade da presença do exercício regular do direito fundamental em apreço. ${ }^{142}$ Afinal, deve-se poder partir, ainda, da presunção absoluta sedimentada há mais de século no brocardo latino jura novit curia.

Por fim, mesmo em se presumindo, na falta de elementos que indicassem uma total omissão do exame judicial específico, constitucionalmente ordenado como primeira decorrência do vínculo do órgão judiciário ao direito fundamental estudado, permanece questionável se $\mathbf{S C}$ representa, enfim, a imposição de um legítimo limite ao direito fundamental, materialmente falando. Limite este que para ser considerado como tal, por sua vez, precisaria ter respeitado o limite, em sentido

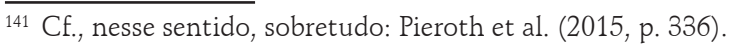

142 Não há consenso na literatura juspenalista pátria a respeito da interpretação do elemento típico da "medida legal". Supostamente, segundo algumas abordagens gerais e generalizantes a seguir referidas, as opiniões variariam entre um entendimento do conceito mais restritivo a posições jurídico-individuais por pressuporem a mera aparência de legalidade, resolvendo-se o problema da possível verificação da ilegalidade com cominação do eventual abuso de poder, passando por autores que preconizam uma manifesta ilegalidade para que a conduta do acusado, uma vez verificada a ilegalidade no bojo do processo penal, não possa ser considerada típica, até algumas posições mais extremadas do minimalismo penal que consideram qualquer resistência a atos não manifestamente legais como não apenas legítima, mas até ensejada por um dever de oposição de resistência. Nesse sentido, com diferentes acentos, mas na tendência unânimes em identificar as três referidas linhas, manifestaram-se, entre outros: Noronha (1998, p. 305), Greco (2012, p. 494-495), Prado (2010, p. 557), Capez (2007, p. 481, 487-488), Delmanto (2007, p. 816, 819), Mirabette (2003, p. 362) e Bitencourt (2010, p. 199). Não há necessidade aqui de se optar por uma dessas posições. Deve ser observado apenas que resolver a questão especificamente penal no âmbito da tipicidade não parece indicado, pois o tipo penal foi mesmo cunhado por um conceito muito amplo. Considerando seu propósito, não faria sentido o atingido pela medida fazer as vezes de juiz em causa própria, constatando a ilegalidade da medida. Afirmada a tipicidade da conduta, ela também é culpável, havendo o dolo específico. A questão penal resolve-se, como em geral no caso de tais intersecções entre direito constitucional e direito penal, no âmbito da antijuridicidade, que pode ser afastada com uma das causas de sua exclusão que é a percepção do exercício regular de direito (art. 23, III, 2a alt. CPB) fundamental. Esta deverá ser especialmente considerada pelo juiz que interpreta sistematicamente a legislação penal de maneira orientada pelo direito fundamental à liberdade de reunião como parte da observância de seu vínculo específico a ele, conforme já sedimentado no presente artigo. No direito penal alemão, que na parte geral conhece apenas as excludentes da legítima defesa e estado de necessidade, foi acrescido a crimes contra a honra, notadamente ao crime de injúria (\$185 StGB), o \$193 StGB: "percepção de legítimos interesses". Este tem sido majoritariamente interpretado como causa excludente da antijuridicidade ou "fundamento especial de justificação", que pode ser entendido como uma especificação daquela. Cf. Sinn (2014, p. 1248 s.) com referência expressa a não mais defesa das teorias da exclusão da culpabilidade e minoritária da exclusão da tipicidade. Essa norma desempenhou um papel relevante na chamada Decisão "Soldados são Assassinos” do TCF alemão. Cf. Martins (2005, p. 414-427).
} 
contrário, derivado da própria tutela do direito fundamental em tela. Especificamente, há de ser perscrutado se o órgão judiciário observou o critério da proporcionalidade. ${ }^{143}$

\subsection{Proporcionalidade da interpretação e aplicação em SC}

Proporcional seria o meio de intervenção estatal implícito em $\mathbf{S C}$ se pudesse ser considerado adequado e necessário em relação a um propósito lícito e permitido constitucionalmente.

\subsection{1 Licitude e admissibilidade do propósito perseguido}

Como verificado, os aplicados art. 329 e 331, tipificadores, respectivamente, dos crimes de resistência e desacato, protegem a "Administração em geral". Com isso, o legislador penal assegura as condições de aceitação (vedação do desacato) da autoridade policial junto aos cidadãos em geral e, para o caso em exame, combate o risco de frustração da detenção necessária à garantia da capacidade funcional dos órgãos de persecução penal (resistência). ${ }^{144}$ Trata-se de um propósito que encontra respaldo em norma constitucional definidora da missão dos órgãos policiais (art. 144, caput CF). Sistematicamente, na qualidade de direito constitucional colidente, é autorizado pelo próprio teor do art. $5^{\circ}$, XVI CF na medida em que a atuação policial visa a, antes de tudo, fazer cumprir o limite expresso de não frustração de outra reunião convocada para o mesmo local ou, no caso específico em comento, para um local adstrito ao local da reunião antes iniciada. Uma investigação mais aprofundada do alcance dos conceitos de "mesmo local" e de "frustração" no sentido do art. 5 XVI CF não precisa ser neste momento perpetrada para efeitos da presente etapa do exame. Isso porque, pelos fatos descritos no caso, a reunião do Partido Z, havida no contexto de uma campanha eleitoral, não foi propriamente "frustrada", o que teria ocorrido se houvesse a impossibilidade de sua realização, mas no máximo tão somente estorvada pela reunião convocada e liderada por $\mathbf{B}$.

Logo, o propósito da intervenção é lícito e admitido pelo limite constitucional previsto pelo art. $5^{\circ}$, XVI c.c. art. 144 , caput CF.

\footnotetext{
${ }_{143}$ Ou princípio da proporcionalidade em sentido amplo, em que há a exclusão da aplicação do não racionalmente controlável subprincípio da proporcionalidade em sentido estrito, que ora sopesa bens, princípios, valores ou interesses abstratamente; ora as vantagens e desvantagens que concretamente advêm da intervenção estatal na liberdade. Ambos fazem parte, todavia, da competência das instâncias político-legislativas. Cf. a análise aprofundada de Dimoulis e Martins (2014, p. 218-229). É muito temerário que a literatura e a jurisprudência pátrias ainda tratem essa medida para a justificação de intervenções em direitos fundamentais de liberdade como porta de entrada para juízos ponderativos os mais indisciplinados e que, às vezes, redundam até na inversão do ônus argumentativo (cf. nota 154).

144 Cf. novamente as referências à nota 87.
} 


\subsection{Licitude e admissibilidade do meio utilizado}

Segundo a descrição do caso, no entendimento do representante de $\mathbf{B}, \mathbf{S C}$ acabou reconhecendo uma prisão ilícita como se lícita fosse. Também sua resistência não seria punível segundo ele porque a detenção teria sido ilegal. Independentemente da avaliação jurídico-penal específica envolvendo a aplicação dos dois tipos penais, um exame que pode ser deixado aqui de lado ou em aberto, ${ }^{145}$ presume-se que a medida judicial (SC), per se, tal qual prolatada pelo juiz natural, não seja lato sensu ilícita constitucionalmente, mesmo porque erros quanto à interpretação e aplicação de tipos penais em si, isto é, sem a verificação da incompatibilidade normativa vertical, não têm o condão de atingir a licitude do meio de intervenção, aqui consubstanciada em SC. ${ }^{146}$

De resto, presume-se legal - pelo menos em princípio e em sentido estrito (base tão somente no parâmetro normativo legal; não no constitucional) - a detenção perpetrada por $\mathbf{P}$. Isso porque a argumentação de $\mathbf{B}$, que se presume também fiel aos fatos, ${ }^{147}$ ou seja, que partiu da convicção da ilegalidade da medida policial da ordem para a entrega do alto-falante, pode estar em tese amparada em uma possível causa excludente da antijuridicidade penal presente na hipótese de ter ocorrido uma percepção de direito fundamental (exercício regular de direito: no caso, de direito decorrente de norma dotada de supremacia e, portanto, superior à norma penal). Se este é mesmo o caso, apenas se pode concluir após a aplicação final dos subcritérios da adequação e necessidade a seguir. Somente ela revelará se se está diante de uma intervenção estatal judicial não justificada na área de proteção do direito fundamental à liberdade de reunião, caso em que, correspondentemente, ter-se-ia a hipótese da excludente da antijuridicidade do exercício regular de direito ou não. ${ }^{148}$

Portanto, o meio de intervenção em si não está eivado de ilicitude na espécie.

\footnotetext{
145 Isso porque o exame não deve se ocupar de meros erros quanto à interpretação e aplicação da norma penal em si, mas, por decorrência do princípio do juiz natural, é restrito à verificação ou não de compatibilidade normativa vertical. V. a assertiva sempre reiterada tanto na jurisprudência quanto na ciência jurídico-constitucional alemãs: simples erros de aplicação de direito infraconstitucional não são objetos idôneos de controle de constitucionalidade. Em estando presentes apenas tais erros, a consequência é a inadmissibilidade, por exemplo, de uma Reclamação Constitucional proposta contra Decisão Judicial. Como instrumento de controle de constitucionalidade movido pelo titular de um direito fundamental supostamente violado e responsável pela grande maioria das decisões de mérito prolatadas pelo TCF alemão, muitas Reclamações Constitucionais não passam no crivo da admissibilidade justamente por essa razão. Para o estabelecimento da competência do TCF em face das jurisdições comum e especiais, usa-se a figura do "direito constitucional específico", acompanhada de relativamente complexas fórmulas que servem à sua verificação no caso concreto. Cf. a síntese do desenvolvimento dessa figura dogmática por Pieroth et al. (2015, p. 333-338) no capítulo final de seu conhecido curso de direitos fundamentais. Sobre a determinação do alcance da jurisdição constitucional na Alemanha mediante a figura do direito constitucional específico e os problemas que esta visa a combater, como o da total constitucionalização do sistema jurídico, v. Martins (2011, p. 40-43, 78, 108 s.).

${ }_{146}$ Principalmente porque o parâmetro do exame é outro, qual seja: o legal, e não o constitucional, restringindo-se o exame em tela ao último. É justamente nesse ponto que se revela a separação entre o exame das observâncias das balizas legais inferiores e superiores da margem de discricionariedade da Administração - no caso, no controle da medida policial revista pelo juiz penal no âmbito do processo penal contra B (legalidade stricto sensu) - e o exame do mérito discricionário em si com pauta na eficácia específica da norma jusfundamental (constitucionalidade).

147 Essa presunção decorre da estrita separação metodológica e orgânico-funcional entre exame probatório e exame jurídico-constitucional em sentido estrito, independentemente da configuração do sistema jurídico-processual de um Estado.

148 A teoria jurídico-penal varia em termos de classificação dogmática das quatro conhecidas excludentes, havendo até mesmo quem defenda a exclusão da tipicidade. Para efeitos da presente exposição e seus resultados, esse debate é despiciendo: não há diferença jurídico-constitucional se se exclui a antijuridicidade, a culpabilidade ou já a tipicidade da conduta.
} 


\subsection{Adequação do meio implícito na interpretação e aplicação das normas penais em SC em face do propósito}

Adequado seria o meio de intervenção em face de seu propósito, ambos verificados, aqui, como o já afirmado ao plano abstrato do controle das normas penais em si, se ele tivesse suscitado uma situação que, com base em hipóteses comprovadas sobre a realidade empírica, tivesse uma conexão com a situação pretendida (realização do propósito). ${ }^{149}$

A ordem de $\mathbf{P}$ para entrega do alto-falante, não atendida por $\mathbf{B}$, e sua subsequente detenção visou a, concreta e especificamente, assegurar o transcurso sem transtornos da reunião convocada para um determinado local pelo Partido Z. Mesmo à revelia da inexistência de regulamentação legislativa do prévio aviso, a ação de $\mathbf{P}$ pode ser, no mais, entendida no sentido de se evitar uma progressão geométrica de uma situação potencialmente conflituosa entre grupos notoriamente rivais; em outras palavras, de dar uma resposta imediata a um perigo concreto localmente verificado. ${ }^{150}$

A efetiva interrupção do discurso de oposição de $\mathbf{B}$ e sua detenção com fulcro no tipo penal do desacato têm uma relação empiricamente comprovável com os propósitos perseguidos, tais quais os subsumidos sob o art. 144, caput CF, quais sejam: de prevenção de distúrbios à segurança e à ordem públicas e de proteção preventiva a ataques deliberados a bens jurídicos relevantes como a integridade física e os patrimônios público e privado. Também a aplicação do tipo penal da resistência à prisão visou a assegurar, concretamente, a capacidade funcional do órgão de polícia, em prol da realização do propósito-fim que é a garantia da segurança pública. Portanto, a corroboração judicial estabelecida em SC é inquestionável em face de sua adequação.

\subsection{Necessidade do meio de intervenção}

Necessário será, todavia, o meio de intervenção adotado pelo Estado tão somente se não houver alternativa igualmente adequada, mas menos impactante no direito fundamental atingido. Traça-se aqui o limite ao limite do direito fundamental, plasticamente alcunhado de vedação de excesso, ${ }^{151}$ que marca o cumprimento ou não do ônus argumentativo estatal implícito nessa fase do exame que, por seu turno, é composta pela tentativa de justificação constitucional da intervenção estatal.

Não restam dúvidas de que o meio adequado escolhido implica um grande impacto no direito fundamental à liberdade de reunião. Não apenas o sancionamento a posteriori da conduta revela-o, como, principalmente, o fático impedimento perpetrado por $\mathbf{P}$ do comportamento de $\mathbf{B}$ con-

\footnotetext{
$\overline{149}$ Cf. Pieroth et al. (2016, p. 72) e Dimoulis e Martins (2014, p. 203).

150 Cf. explicações e referências à nota 83.

151 Que é uma tradução adequada do decisivo subprincípio constituinte do princípio da proporcionalidade que é a necessidade.

Cf. Dimoulis e Martins (2014, p. 188-192, 210-217).
} 
templado pela tutela do art. $5^{\circ}$, XVI CF na medida em que a partir da ordem para entrega do alto-falante foi iniciado um processo de tumulto que redundou na sua prisão.

Várias medidas concretas, igualmente adequadas, mas notoriamente menos intensas, viriam à pauta, a começar pela mera presença e observação policial do transcurso de ambas as reuniões com intervenções pontuais para se impedir eventuais agressões entre o grupo de $\mathbf{B}$ e o Partido Z ${ }^{152}$

Pela descrição dos fatos, o uso do alto-falante não teve o condão de encobrir totalmente os discursos proferidos pelos membros do Partido Z. Trata-se de proselitismo ideológico de parte a parte, perpetrado em praça pública, e, como tal, de exercício da liberdade de reunião e da com ela concorrente liberdade de manifestação do pensamento.

Nesse sentido, a primeira medida da ordem de $\mathbf{P}$ para a entrega do alto-falante com vistas a interromper o transtorno da reunião já antes iniciada do Partido $\mathbf{Z}$ e as dele decorrentes ameaças à segurança e ordem públicas, embora seja, em princípio, uma medida pertinente à discricionariedade policial, revelou-se excessiva diante do propósito perseguido. A detenção que se seguiu interrompeu abruptamente o comportamento tutelado pela norma constitucional, que é o uso do próprio corpo ${ }^{153}$ para a comunicação social de uma dada reivindicação ou expressão de opinião pertinente ou não à formação da opinião pública.

Assim, a reiteração da medida interventiva policial por SC baseou-se em uma falsa avaliação judicial quanto à sua proporcionalidade: meios alternativos pertinentes à discricionariedade policial, notoriamente menos impactantes, poderiam ter sido utilizados.

Logo, SC não observou o critério da necessidade. Assim, ela é desproporcional em sentido lato na medida em que viola a vedação do excesso decorrente do sistema constitucional pátrio. ${ }^{154}$

\footnotetext{
152 A Lei Federal de Reuniões prevê uma série de medidas adequadas que, comparadas a medidas policiais gerais derivadas da cláusula geral de prevenção e combate a perigos e outras estandardizadas e positivadas em leis estaduais "policiais" ou "gerais de segurança pública" (legi generali), são, na qualidade de legi speziali, que implicam o efeito de bloqueio da aplicação das normas estaduais policiais (Polizeifestigkeit des Versammlungsrechts) notoriamente menos intensas. Note-se que entre as referidas leis estaduais e a Lei Federal de Reuniões há uma dupla relação de especificidade. A primeira relação dessa natureza ocorre dentro do próprio direito objetivo policial que é composto pelas leis estaduais: entre sua mencionada cláusula geral e as medidas estandardizadas também nela previstas. A segunda relação de especificidade ocorre entre aquele e o direito objetivo de reunião constituído pela aludida Lei Federal e, após uma reforma constitucional derrogadora da distribuição das competências legislativas federativas, também por leis estaduais. Entre as principais medidas positivadas na Lei Federal de Reunião que vêm à pauta, citem-se: i. a exclusão de partícipe que, entre outros, estorve o pacifismo de uma reunião (mesma consequência jurídica para três suportes fáticos dos $\$$ \ 17a, IV; 18 III; 19 IV VersG) e ii. a dissolução (\$15, III VersG), desde que presentes os estritos pressupostos legais para sua proibição (\$15, I VersG). Cf. por todos, a muito sistemática apresentação de Gusy (2014, p. 264-269).

${ }^{153}$ Cf. nesse sentido, novamente: Kniesel e Poscher (2007, p. 1009 ss.).

${ }^{154}$ A literatura germânica especializada e também a jurisprudência do TCF são marcadas pela opinião majoritária de que a avaliação das intensidades interventivas deve ser feita na terceira etapa da proporcionalidade em sentido estrito. Trata-se de um equívoco que já foi verificado repetidas vezes por uma posição minoritária (SCHLINK, 1976; SCHLINK, 1984; SCHLINK, 2001; PIEROTH et al., 2015) aqui representada. Em verdade, a avaliação das intensidades não implica uma discussão de consequências da intervenção para os bens jurídicos, de lastro direto ou indireto (via reservas legais) na Grundgesetz ou na CF. Contudo, essa divergência acaba sendo pouco relevante quando, por exemplo, o TCF alemão inobstante a alcunha de proporcionalidade em sentido estrito aplica, em verdade, o exame da necessidade, ou seja, acaba sendo, pelo menos em parte, uma divergência apenas teórico-terminológica. Por sua vez, na recepção e discussão pátrias de figuras jurídico-dogmáticas importadas como proporcionalidade e "proibição de excesso", inverte-se, muito temerariamente, o aqui repetidas vezes aplicado ônus argumentativo, decorrente do princípio distributivo marcado por Carl Schmitt há quase um século e que orienta a fase do exame da justificação constitucional. Não raramente, isso resulta na aplicação da vedação do excesso à conduta do titular do direito e não ao órgão estatal. Isso ocorre sem embargo da pomposa, mas absolutamente ignorante menção ao vocábulo
} 


\subsubsection{Conclusão geral}

A intervenção estatal, consubstanciada em SC, na área de proteção do direito fundamental à liberdade de reunião de $\mathbf{B}$ não restou justificada. Portanto, SC violou o art. $5^{\circ}, \mathrm{XVI}$ CF.

Consequentemente, a alegação de $\mathbf{B}$ - delimitadora do objeto do presente parecer - é procedente.

\section{Conclusões e perspectivas}

A verificação das omissões e equívocos na abordagem pátria de tão relevante direito fundamental para o processo democrático e para o desenvolvimento da personalidade individual pela via de sua associação corpórea com outras personalidades torna imprescindível uma sóbria abordagem, a qual se tentou perpetrar no presente ensaio. Ilustrou-a o estudo de caso, por intermédio do qual se demonstrou a efetividade da dogmática e métodos jurídicos adotados a partir dos instrumentos refletidos e construídos sob a égide de uma teoria liberal do direito fundamental à liberdade de reunião. Sistematicamente, podem ser depreendidas do desenvolvimento das análises teóricas, dogmáticas e práticas apresentadas as seguintes conclusões:

1. O teor do dispositivo do art. $5^{\circ}$, XVI CF revela uma complexidade em relação à qual as manifestações da literatura jurídica e da jurisprudência nacionais estão muito aquém.

2. Também a liberdade de reunião, assim como acontece com todos os direitos fundamentais de liberdade, prescinde de qualquer regulamentação legislativa, por força do art. $5^{\circ}, \mathbb{S} 1^{\circ} \mathrm{CF}$. Todavia, isso não implica aceitar a tese de que uma regulamentação seria, de plano, inconstitucional. Não obstante, qualquer regulamentação como produto de poder constituído deve vir acompanhada de uma salutar suspeita de inconstitucionalidade, que somente poderá ser sanada com o devido exame sistemático aqui proposto.

3. Do exame sistemático (análise do contexto normativo) faz parte, sobretudo, a diferenciação entre as condições subjetivas para o exercício da liberdade de reunião (caráter pacífico, não porte de armas) e os limites previstos no próprio dispositivo constitucional, implícitos nas locuções da "exigência" de "prévio aviso a autoridade competente" e da "não frustração" de outra reunião "an-

em alemão Ubermassverbot, até mesmo por juristas que têm influenciado a mais nova geração de operadores do sistema jurídico, como demonstra o uso da figura na seguinte contribuição, justamente em um brevíssimo ensaio publicado em blog eletrônico sobre liberdade de reunião por ocasião do impacto das grandes manifestações de junho de 2013: "A razoabilidade no exercício das reuniões e passeatas, previstas constitucionalmente, deve, portanto, evitar [sic] a ofensa aos demais direitos fundamentais, o desrespeito à consciência moral da comunidade, visando, em contrapartida, a esperança fundamentada de que se possa alcançar um proveito considerável para todos, resultante na prática democrática do direito de reivindicação. Trata-se da cláusula de proibição de excesso (Übermassverbot) consagrada pelo Tribunal Constitucional alemão [...]." (MORAES, 2013). Essa passagem citada revela, de resto, um desvio conceitual bastante grave: parece querer submeter o exercício de direitos fundamentais a uma cláusula condicional do suposto benefício coletivo que dele deveria decorrer. Não se sabe quão consciente ocorreu essa espécie de retorno à concepção de liberdade vigente, ainda que com um recorte social-estamental, no ancien régime. Não obstante, fato é que de tais abordagens superficiais e descabidas, pretende-se se afastar aqui com os esforços analíticos e bem documentados (respeito às fontes!) empenhados. 
teriormente convocada para o mesmo local". Na pior das hipóteses, tais locuções apresentam limites decorrentes do chamado direito constitucional de colisão.

4. Tanto a percepção e efetiva persecução via legislação ordinária de tais limites quanto sua intepretação e aplicação pelo Judiciário devem observar as peculiaridades de cada vínculo funcional ao direito fundamental derivado do art. $5^{\circ}$, XVI CF.

5. Todos os órgãos titulares de poderes constituídos envolvidos devem observar o limite à sua competência para limitar direito fundamental decorrente do princípio da proporcionalidade.

Como perspectivas do próximo desenvolvimento dos estudos, políticas e práticas em torno do direito fundamental do art. $5^{\circ}$, XVI CF em médio e longo prazos, há de se pontuar as seguintes demandas:

1. Em âmbito de pesquisa jurídica, há de ser muito mais bem esmiuçado o fenômeno do exercício do poder de polícia por órgãos administrativos e pelas polícias militares e civis, respectivamente no âmbito de suas atribuições, dos Estados-membros.

2. Em âmbito de políticas legislativas e de gestão ("políticas públicas"), há de se trabalhar com os resultados das pesquisas especificamente jurídicas, considerando a idônea informação de todos os projetos de lei e medidas executivas de gestão para a área. $\bigcirc$ debate seria tão mais profícuo quanto mais se conscientizasse, a partir do exame de sistemas jurídicos estrangeiros como o alemão, do papel de um sistema normativo infraconstitucional que reduzisse todas as discricionariedades oficiais a um mínimo necessário, com vistas à promoção da força normativa do art. $5^{\circ}$, XVI CF. Um dos resultados desse processo poderia ser o surgimento do direito geral de ordem e de segurança públicas como sub-ramo do direito administrativo.

3. Finalmente, em âmbito de interpretação judicial, que pode ser muito beneficiada com um possível e auspicioso desenvolvimento dos dois âmbitos anteriores, o estudo da dogmática jurídica desenvolvida tanto pela literatura especializada quanto pela jurisprudência de Estados democráticos muito desenvolvidos como o alemão afiançaria o alcance de uma jurisprudência segura, consistente e plenamente compatível com seu vínculo específico e papel dentro do Estado democrático de direito.

\section{Referências}

ALEXY, Robert. Grundrechte als subjektive Rechte und als objektive Normen. Der Staat, v. 29, p. 73-107, 1990.

BADURA, Peter. Staatsrecht. Systematische Erläuterung des Grundgesetzes für die Bundesrepublik Deutschland. 6. ed. ampl. Beck: München, 2015.

BAPTISTA, Patrícia. Transformações do Direito Administrativo. Rio de Janeiro: Renovar, 2013. 
BARROSO, Luís Roberto. Neoconstitucionalismo e constitucionalização do direito: $\bigcirc$ triunfo tardio do direito constitucional no Brasil. Revista de Direto Administrativo, v. 240, p. 1-42, abr./jun. 2005.

BINENBOJM, Gustavo. Uma Teoria do Direito Administrativo: direitos fundamentais, democracia e constitucionalização. 3. ed. Rio de Janeiro: Renovar, 2014.

BITENCOURT, Cezar Roberto. Tratado de Direito Penal. Parte especial: dos crimes contra a administração pública, dos crimes praticados por prefeitos. São Paulo: Saraiva, 2010.

BÖCKENFÖRDE, Ernst-Wolfgang. Grundrechte als Grundsatznormen - Zur gegenwärtigen Lage der Grundrechtsdogmatik. Der Staat, v. 29, p. 1-31, 1990.

BRANCO, Paulo Gustavo G. Comentários ao art. 5 XVI a XXI. In: CANOTILHO, José Joaquim Gomes et al. Comentários à Constituição do Brasil. São Paulo: Saraiva, Almedina, 2014. p. 304-312.

BULL, Hans Pete; MEHDE, Veith. Allgemeines Verwaltungsrecht: mit Verwaltungslehre. 9. ed. Heidelberg: Müller, 2015.

BUMKE, Christian. Ausgestaltung von Grundrechten. Grundlagen und Grundzüge einer Dogmatik der Grundrechtsausgestaltung unter besonderen Berücksichtigung der Vertragsfreiheit. Tübingen: Mohr Siebeck, 2009.

BUMKE, Christian. Der Grundrechtsvorbehalt: Untersuchungen über die Begrenzung und Ausgestaltung der Grundrechte. Baden-Baden: Nomos, 1998, Studien und Materialien zur Verfassungsgerichtsbarkeit, v. 749.

CAPEZ, Fernando. Curso de Direito Penal: parte especial. 5. ed. São Paulo: Saraiva, 2007. v. 3.

CARVALHO FILHO, José do Santos. Manual de Direito Administrativo. 11. ed. Rio de Janeiro: Lumen Juris, 2004.

CORNILS, Matthias. Die Ausgestaltung der Grundrechte: Untersuchungen zur Grundrechtsbindung des Ausgestaltungsgesetzgebers. Tübingen: Mohr Siebeck, 2005.

CRUZ, José Raimundo Gomes da. O controle jurisdicional do processo disciplinar. São Paulo: Malheiros, 1996.

DelmanTO, Celso et al. Código Penal Comentado. 7. ed. Rio de Janeiro: Renovar, 2007.

DETTERBECK, Steffen. Allgemeines Verwaltungsrecht: mit Verwaltungsprozessrecht. 14. ed. München: Beck, 2016.

DI PIETRO, Maria Sylvia Zanella. Direito Administrativo. 24. ed. São Paulo: Atlas, 2011.

DIAS, Roberto; DE LAURENTIIS, Lucas. Liberdade de reunião e democracia: reflexões a partir das experiências brasileiras e alemãs. Revista Brasileira de Estudos Constitucionais, v. 8, n. 30, p. 649-669, set./dez. 2014.

DIMOULIS, Dimitri. Direito penal constitucional: garantismo na perspectiva do pragmatismo jurídico-político. Belo Horizonte: Arraes, 2016. 
DIMOULIS, Dimitri. Direitos fundamentais e democracia. Da tese da complementaridade à tese do conflito. Revista Brasileira de Estudos Constitucionais, v. 1, p. 200-214, 2007.

DIMOULIS, Dimitri; LUNARDI, Soraya. Curso de processo constitucional. 4. ed. rev., atual. e ampl. São Paulo: Atlas, 2016.

DIMOULIS, Dimitri; MARTINS, Leonardo. Teoria geral dos direitos fundamentais. 5. ed. rev., atual. e ampl. São Paulo: Atlas, 2014.

DIMOULIS, Dimitri. Significado e atualidade da separação de poderes. In: AGRA, Walber de Moura; CASTRO, Celso Luiz Braga de; TAVARES, André Ramos. Constitucionalismo. Os desafios no terceiro milênio. Belo Horizonte: Forum, 2008. p. 143 ss.

DREIER, Horst. Artikel 1 III [Grundrechtsbindung]. In: DREIER, Horst. Grundgesetz-Kommentar. Artikel 1-19. 3. ed. Tübingen: Mohr Siebeck, 2013. v. 1. p. 280-329.

DREIER, Horst. Artikel 19 II [Grundrechtseinschränkung]. In: DREIER, Horst. Grundgesetz-Kommentar. Artikel 1-19. 3. ed. Tübingen: Mohr Siebeck, 2013. v. 1. p. 1721-1734.

ENDERS, Christoph et al. Musterentwurf eines Versammlungsgesetzes. München: Beck, 2011.

ERBGUTH, Wilfried. Allgemeines Verwaltungsrecht: mit Verwaltungsprozess- und Staatshaftungsrecht. 8. ed. Baden-Baden: Nomos, 2016.

FRANÇA, Vladimir da Rocha. Direito de reunião pacífica da Constituição Federal. Revista de Direito Constitucional e Internacional, v. 15, n. 61, p. 280-297, out./dez. 2007.

FRANÇA, Vladimir da Rocha. Invalidação Judicial da Discricionariedade Administrativa: no regime jurídico-administrativo brasileiro. Rio de Janeiro: Forense, 2000.

FREITAS, Juarez. Discricionariedade administrativa e o direito fundamental à boa Administração Pública. São Paulo: Malheiros, 2007.

FREITAS, Juarez. O controle dos atos administrativos e os princípios fundamentais. 3. ed. rev. e ampl. São Paulo: Malheiros, 2004.

GERBER, Konstantin. Liberdade de reunião que depende de quem, quando e para onde vai. Portal "Justificando" (Carta Capital), 15 ago. 2016. Disponível em: <http://justificando.cartacapital.com. br/2016/08/15/liberdade-de-reuniao-que-depende-de-quem-quando-e-para-onde-vai/ > . Acesso em: 24 fev. 2017.

GRECO, Rogério. Curso de Direito Penal: parte especial. 8. ed. Niterói: Ímpetus, 2012. v. 5.

GRIMM, Dieter. Die Meinungsfreiheit in der Rechtsprechung des Bundesverfassungsgerichts. Neue Juristische Wochenschrift - NJW, p. 1697-1705, 1995.

GUSY, Christoph. Polizei- und Ordnungsrecht. 9. ed. Tübingen: Mohr Siebeck, 2014.

HOFFMANN, Harald; GERKE, Jürgen; HILDEBRANDT, Uta. Allgemeines Verwaltungsrecht. 11. ed. Stuttgart: Kohlhammer, 2016. 
HÖFLING, Wolfram. Art. 8 I [Versammlungsfreiheit]. In: SACHS, Michael (Org.). Grundgesetz: Kommentar. 7. ed. München: Beck, 2014. p. 430-455.

HUFEN, Friedehelm. Staatsrecht II. Grundrechte. 5. ed. München: C.H. Beck, 2016.

HUSTER, Stefan. Die ethische Neutralität des Staates: eine liberale Interpretation der Verfassung. Tübingen: Mohr Siebeck, 2002.

JARASS, Hans D. Vorbemerkung vor Art. 1. In: JARASS, Hans D.; PIEROTH, Bodo. Grundgesetz für die Bundesrepublik Deutschland: Kommentar. 12. ed. München: Beck, 2011. p. 15-37.

JARASS, Hans D. Vorbemerkung vor Art. 1. In: JARASS, Hans D.; PIEROTH, Bodo. Grundgesetz für die Bundesrepublik Deutschland: Kommentar. 14. ed. München: Beck, 2016. p. 294-304.

JESUS, Damásio E. de. Direito penal. 4. ed. São Paulo: Saraiva, 1997.

KNIESEL, Michael; POSCHER, Ralf. Versammlungsrecht. In: LISKEN, Hans; DENNINGER, Erhard (Org.). Handbuch des Polizeirechts. 4. ed. München: C. H. Beck, 2007. p. 1009-1110.

KOLL, Berend. Liberales Versammlungsrecht. Zum Stellenwert der Freiheit in den Versammlungsgesetzen. Baden-Baden: Nomos, 2015.

KRELL, Andreas J. Discricionariedade administrativa e proteção ambiental: o controle dos conceitos jurídicos indeterminados e a competência dos órgãos ambientais: um estudo comparado. Porto Alegre: Livraria do Advogado, 2004.

KUGELMANN, Dieter. Die informatorische Rechtsstellung des Bürgers. Tübingen: Mohr Siebeck, 2001.

LIMA, Ruy Cirne. Princípios de direito administrativo. 7. ed. Malheiros: São Paulo, 2007.

LOEWENSTEIN, Karl. Militant Democracy and Fundamental Rights. American Political Science Review, v. 31, p. 417-433 e 638-658, 1937.

MAGER, Ute. Staatsrecht II. Grundrechte. 6. ed. totalmente reformulada. Stuttgart: Kohlhammer, 2004.

MANSSEN, Gerrit. Staatsrecht II. Grundrechte. 13. ed. München: Beck, 2016.

MARTINS, Leonardo. A retórica do processo constitucional objetivo no Brasil: breves considerações de constitutione ferenda. In: NOVELINO, Marcelo (Org.). Leituras complementares de direito constitucional: controle de constitucionalidade e hermenêutica constitucional. 3. ed. rev., ampl. e atual. Salvador: Jus Podivm, 2010. p. 127-146.

MARTINS, Leonardo. ADPF 187/DF: Marcha da Maconha. In: ANJOS FILHO, Robério dos (Org.). STF e direitos fundamentais. Diálogos contemporâneos. Salvador: Juspodivm, 2013 p. 277-305.

MARTINS, Leonardo. Bioética à luz da liberdade científica: estudo de caso baseado na decisão do STF sobre a constitucionalidade da lei de biossegurança e no direito comparado alemão. São Paulo: Atlas, 2014.

MARTINS, Leonardo. Cinquenta anos de jurisprudência do Tribunal Constitucional Federal alemão. Montevideu: Konrad-Adenauer-Stiftung, 2005. 
MARTINS, Leonardo. Descriminalização das Drogas. Possibilidade. Carta Forense, jul. 2015.

MARTINS, Leonardo. Direitos fundamentais à intimidade, à vida privada, à honra e à imagem (art. $5^{\circ}$, X da CF): alcance e substrato fático da norma constitucional (intervenção estatal potencialmente violadora). Ius Gentium. v. 7, n. 1. p. 105-132, 2016 a.

MARTINS, Leonardo. Direito processual constitucional alemão. São Paulo: Atlas, 2011.

MARTINS, Leonardo. "Eigentum verpflichtet" auf Portugiesisch. Was kann die brasilianische Verfassungsrechtswissenschaft vom angewandten Art. 14 Absatz 2 Grundgesetz lernen? In: PLÖSE, M. et al. "Worüber reden wir eigentlich?" Festgabe für Rosemarie Will. Berlin: Humanistische Union, 2016b. p. 445-461.

MARTINS, Leonardo. Liberdade e Estado constitucional: leitura jurídico-dogmática de uma complexa relação a partir da teoria liberal dos direitos fundamentais. São Paulo: Atlas, 2012a.

MARTINS, Leonardo. Reunião (liberdade de). In: DIMOULIS, Dimitri (Org.). Dicionário brasileiro de direito constitucional. São Paulo: Saraiva, 2012b. p. 363-364.

MARTINS, Leonardo. Tribunal Constitucional Federal alemão: decisões anotadas sobre direitos fundamentais [obra em 5 volumes. Vol. 1: Dignidade humana, livre desenvolvimento da personalidade, direito fundamental à vida e à integridade física, igualdade]. 2016c.

MARTINS, Leonardo. Tribunal Constitucional Federal alemão: decisões anotadas sobre direitos fundamentais [obra em 5 volumes. Vol. 2: Liberdade de consciência e crença, liberdades de expressão do pensamento e de comunicação social, liberdades artística e científica]. 2017 (no prelo).

MAURER, Hartmut. Allgemeines Verwaltungsrecht. 18. ed. München: Beck, 2011.

MELLO, Oswaldo Aranha Bandeira. Princípios Gerais de Direito Administrativo. 3. ed. Vol. 1. São Paulo: Malheiros, 2007.

MENDES, Gilmar Ferreira; BRANCO, Paulo Gustavo Gonet. Curso de direito constitucional. 12. ed. rev. e atual. São Paulo: Saraiva, 2017.

MENDES, Gilmar Ferreira. Jurisdição constitucional: o controle abstrato de normas no Brasil e na Alemanha. São Paulo: Saraiva, 2004.

MENDES, Gilmar Ferreira. Os direitos individuais e suas limitações. Breves reflexões. In: MENDES, Gilmar Ferreira et al. Hermenêutica constitucional e direitos fundamentais. Brasília: Brasília Jurídica, 2000.

MEZZAROBA, Orides. Comentários ao art. 17. In: CANOTILHO, José Joaquim Gomes et al. Comentários à Constituição do Brasil. São Paulo: Saraiva: Almedina, 2013. p. 690-699.

MICHAEL, Lothar; MORLOK, Martin. Grundrechte. 5. ed. Baden-Baden: Nomos, 2016.

MIRABETTE, Júlio Fabrini. Manual de direito penal. 18. ed. São Paulo: Saraiva, 2003.

MIRANDA, Jorge. Manual de direito constitucional. 3. ed. Coimbra: Coimbra Editora, 2000. 
MÖLLERS, Martin H. W. Polizei und Grundrechte. Ein Lehrbuch zu den Menschenrechten in der polizeilichen Praxis. 3. ed. atual. e ampl. Frankfurt: Verlag für Polizeiwissenschaft, 2015.

MORAES, Alexandre de. Passeatas são legítimas, mas devem respeitar democracia. Consultor Jurídico, 14 jun. 2013. Disponível em: <http://www.conjur.com.br/2013-jun-14/justica-comentada-passeatas-sao-legitimas-respeitar-democracia >. Acesso em: 07 abr. 2017.

NASCIMENTO, Filippe Augusto dos Santos. A dimensão objetiva dos direitos fundamentais: conceito e sistematização. Porto Alegre: Fabriz, 2016. [publ. da Dissertação (Mestrado em Direito) - Universidade Federal do Rio Grande do Norte, Natal, 2013].

NORONHA, Edgard Magalhães. Direito penal. São Paulo: Saraiva, 1998.

NUCCI, Guilherme de Souza. Manual de direito penal. Parte Geral e Especial. 6. ed. São Paulo: Revista dos Tribunais, 2009.

OLIVEIRA, Renata Camilo de Oliveira. Zur Kritik der Abwägung in der Grundrechtsdogmatik: Beitrag zu einem liberalen Grundrechtsverständnis im demokratischen Rechtsstaat.Berlin: Duncker \& Humblot, 2013.

PEINE, Franz-Joseph. Allgemeines Verwaltungsrecht. 11. ed. Heidelberg: Müller, 2014.

PIEROTH, Bodo et al. Grundrechte. Staatsrecht II. 31. ed. Heildelberg: C.F. Müller, 2015.

PIEROTH, Bodo et al. Polizei- und Ordnungsrecht. Mit Versammlungsrecht. 9. ed. München: C.H. Beck, 2016.

POSCHER, Ralf. Grundrechte als Abwehrrechte: Reflexive Regelung rechtlich geordneter Freiheit. Tübingen: Mohr Siebeck, 2003.

PRADO, Luiz Regis. Curso de Direito penal brasileiro. Vol. 3: parte especial. Artigos 250 a 259-H. 7. ed. São Paulo: Revista dos Tribunais, 2010.

SACHS, Michael. Verfassungsrecht II - Grundrechte. Berlin: Springer, 2016.

SARLET, Ingo Wolfgang; WEINGARTNER NETO, Jayme. Democracia desmascarada?: liberdade de reunião e manifestação: uma resposta constitucional contra-hegemônica. Direitos fundamentais e jurisdição constitucional. São Paulo: Revista dos Tribunais, 2014. p. 477-496.

SAUERLAND, Thomas. Allgemeines Verwaltungsrecht. München: C.H. Beck, 2015.

SCHENKE, Wolf Rüdiger. Polizei- und Ordnungsrecht. 9. ed. Heidelberg: Müller, 2016.

SCHILDHEUER, Frank. Grundrechte. 4. ed. Frankfurt: Jura Intensiv Verlag, 2015.

SCHLAICH, Klaus; KORIOTH, Stefan. Das Bundesverfassungsgericht: Stellung, Verfahren, Entscheidungen. 10. ed. München: Beck, 2015.

SCHLINK, Bernhard. Bemerkungen zum Stand der Methodendiskussion in der Verfassungsrechtswissenschaft. Der Staat, v. 19, p. 73-107, 1980. 
SCHLINK, Bernhard. Der Grundsatz der Verhältnismäßigkeit. In: BADURA, Peter; DREIER, Horst (Org.). Festschrift 50 Jahre Bundesverfassungsgericht. Tübingen: Mohr Siebeck, 2001. v. 2.

SCHLINK, Bernhard. Freiheit durch Eingriffsabwehr - Rekonstruktion der klassischen Grundrechtsfunktion. Europäische Grundrechte-Zeitschrift - EuGRZ, v. 1984, p. 457-468, 1984.

SCHLUCKEBIER, Wilhelm. \$240 [Nötigung]. In: SCHLUCKEBIER, Wilhelm et al. Strafgesetzbuch: Kommentar. 2. ed. Köln: Carl Heymanns Verlag, 2014, p. 1465-1472.

SCHMIDT, Rolf. Allgemeines Verwaltungsrecht: Verwaltungsorganisation und Behördenaufbau, Rechtsquellen des Verwaltungsrechts, das subjektive öffentliche Recht, unbestimmter Rechtsbegriff, Beurteilungsspielraum und planerische Abwägungsentscheidungen, Verwaltungsermessen, Handlungsformen der Verwaltung, Staatshaftungsrecht. 19. ed. Grasberg bei Bremen: Dr. Rolf Schmidt GmbH, 2016.

SCHULZE-FIELITZ, Helmuth. Artikel 8 [Versammlungsfreiheit]. In: DREIER, Horst. Grundgesetz-Kommentar. Artikel 1-19. 3. ed. Tübingen: Mohr Siebeck, 2013, p. 1022-1077. v. 1.

SCHWEICKHARDT, Rudolf; VONDUNG, Ute. Allgemeines Verwaltungsrecht. 9. ed. Stuttgart: Kohlhammer, 2010.

SILVA, José Afonso da. Aplicabilidade das normas constitucionais. 6. ed. 3. tir. São Paulo: Malheiros, 2004.

SILVA, José Afonso da. Curso de direito constitucional positivo. 40. ed. rev. e atual. São Paulo: Malheiros, 2017.

SILVA, Virgílio Afonso da. A constitucionalização do direito: os direitos fundamentais nas relações entre os particulares. São Paulo: Malheiros, 2005.

SILVA, Virgílio Afonso da. Direitos Fundamentais: conteúdo, essencial, restrições e eficácia. 2. ed. São Paulo: Malheiros, 2011.

SILVA, Virgílio Afonso da. O conteúdo essencial dos direitos fundamentais e a eficácia das normas constitucionais. Revista de Direito do Estado, v. 4, p. 23-51, 2006.

SINN, Arndt. $₫ 193$ (Wahrnehmung berechtigter Interessen). In: SCHLUCKEBIER, Wilhelm et al. (Org.). Strafgesetzbuch: Kommentar. 2. ed. Köln: Carl Heymanns Verlag, 2014, p. 1248-1254.

SOUSA, António Francisco de.SOUSA, António Francisco. Liberdade de reunião e de manifestação no estado de direito. Direitos Fundamentais e Justiça, v. 6, n. 21, p. 27-38, out./dez. 2012.

STEINMETZ, Wilson. Colisão de direitos fundamentais e princípio da proporcionalidade. Porto Alegre: Livraria do Advogado, 2001.

STEINMETZ, Wilson. O dever de aplicação imediata de direitos e garantias fundamentais na jurisprudência do Supremo Tribunal Federal e nas interpretações da literatura especializada. In: SARMENTO, Daniel; SARLET, Ingo Wolfgang (Org.). Direitos fundamentais no Supremo Tribunal Federal: Balanço e crítica. Rio de Janeiro: Lumen Juris, 2011.

STOBER, Rolf; KLUTH, Winfried. Verwaltungsrecht I. Ein Studienbuch. München: Beck, 2007. 
STORR, Stefan; SCHRÖDER, Rainer. Allgemeines Verwaltungsrecht. Stuttgart: Kohlhammer, 2010.

SUCKOW, Horst; WEIDEMANN, Holger. Allgemeines Verwaltungsrecht und Verwaltungsrechtsschutz: Grundriss für die Aus- und Fortbildung. 16. ed. Stuttgart: Dt. Gemeindeverlag, 2014.

SUNDFELD, Carlos Ari. Ato administrativo inválido. São Paulo: Revista dos Tribunais, 1990.

TAVARES, André Ramos. Curso de direito constitucional. 3. ed. São Paulo: Saraiva, 2006.

THIEL, Markus. Polizei- und Ordnungsrecht. 3. ed. Baden-Baden: Nomos, 2016.

TÖLLE, Oliver. Versammlungsrecht. In: PEWESTORF, Adrian; SÖLLNER, Sebastian; TÖLLE, Oliver (Org.). Polizei und Ordnungsrecht. Kommentar. 2. ed. Köln: Carl Heymanns, 2017. p. 644-711.

TSCHENTSCHER, Axel. Versammlungsfreiheit und Eventkultur - Unterhaltungsveranstaltungen im Schutzbereich des Art. 8 I GG. Neue Zeitschrift für Verwaltungsrecht, p. 1243-1236, 2001.

WALLERATH, Maximilian. Allgemeines Verwaltungsrecht: Lehrbuch. Berlin: Schmidt, 2009.

WIENBRACKE, Mike. Allgemeines Verwaltungsrecht: [mit Online-Wissens-Check]. 4. ed. Heidelberg: Müller, 2015.

ZANCANER, Weida. Da convalidação e da invalidação dos atos administrativos. 2. ed. São Paulo: Malheiros, 1996. Coleção Temas de Direito Administrativo 1.

Data da submissão: 10 de abril de 2017 Avaliado em: 15 de abril de 2017 (AVALIADOR A) Avaliado em: 28 de abril de 2017 (AVALIADOR B) Avaliado em: 08 de maio de 2017 (AVALIADOR C) Aceito em: 31 de maio de 2017 